\title{
The Common Law Origins of \\ Constitutionally Compelled Remedies
}

\author{
Ann Woolhandler ${ }^{\dagger}$
}

\section{CONTENTS}

I. Diversity JURISDICTION AND FEDERAL QUESTIONS . . . . . . . . . 84

A. "General Law" and Diversity . . . . . . . . . . . . . 85

1. The Origins of Diversity Jurisdiction . . . . . . . . 85

2. Use of Diversity to Promote Commercial Interests . . . . 86

B. Diversity's Accommodation of Federal Issues . . . . . . . . 89

1. The Nonpresumption of Parity . . . . . . . . . . . . . 92

2. Shareholder Actions, Trustees, and Diversity . . . . . . . 95

C. Sources of Remedial Rights in Diversity Actions:

The Interstitial Nature of State Law . . . . . . . . . . . . . 99

1. Procedures and Remedies ... . . . . . . . . . . . 102

a. State Limits on Enforcement in Actions at Law . . . . 103

b. State Restrictions on Equity . . . . . . . . . . 104

c. Forum Restrictions . . . . . . . . . . . . 105

2. Elements of Claims .................. 106

a. Parties . . . . . . . . . . . . . 107

b. Elements and Forms of Action . . . . . . . 108

II. Constitutional Questions in State Courts . . . . . . . . . 111

A. Taking the State Courts as They Were . . . . . . . . . . . . 112

B. Taking the State Courts as They Once Were ......... . 113

1. Private Contracts Clause Litigation ...........113

2. State Bond Litigation . . . . . . . . . . . . . 113

a. Auxiliary Promises . . . . . . . . . . . . 115

b. State Remedial Manipulation . . . . . . . . . 117

c. The Example of the Virginia Coupon Cases ...... . 118

d. Constitutionally Required Remedies ... . . . . 120

i. Defenses to Enforcement . . . . . . . . . 122

$\dagger$ Professor of Law, Tulane University. I would like to thank Mary Anne Case. Michatel Collins. Richard Fallon, Barry Friedman, John Harnson. Alfred Hill. John Jeffnes, and John Kramer for theır comments on earlier drafts of this Article. 
ii. Trespass Actions . . . . . . . . . . . 122

iii. Positive Law Remedies . . . . . . . . . . . . . 123

III. Federal Question Cases and the Framework

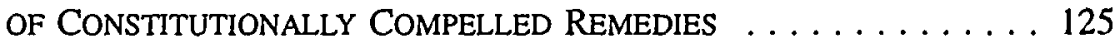

A. Nondiversity Federal Question Cases: Virginia Coupon Redux 126

B. Rate Regulation and the Rise of Due Process . . . . . . . 127

1. The Ambiguous Source of Law for "Reasonableness" . . . 128

2. The Emerging Federalization of General Law Norms . . . 130

C. Compelled Remedies for Illegal State Taxation . . . . . . . 132

1. Federal Injunctions Against Unconstitutional Taxes .... 133

2. Federal Court Damages Actions to Remedy Unconstitutional Taxes .......................... 135

3. Required Tax Remedies in State Courts . . . . . . . . 137

4. State Law Limits on "Legal" Relief in Federal Court . . . 138

5. Federal Injunctions for State Law Violations ......... 144

IV. THE MOdERN SignificANCE OF THE History OF CONSTITUTIONALly COMPELlED REMEdies . . . . . . . . . . . 148

A. Sovereign Immunity and Compelled Remedies in State Courts 149

B. Common Law Remedies and the Constitution:

Old Light on a Modern Dilemma . . . . . . . . . . . . . 154

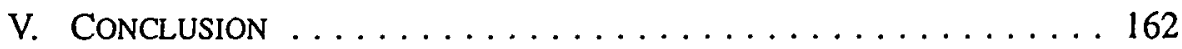


Federal courts scholars see the Reconstruction-era enactment of general federal question jurisdiction ${ }^{\prime}$ as a decisive moment in judicial federalism. The conventional wisdom is that with the $1875 \mathrm{Act}$, Congress gave the federal courts powers that had lain dormant in the Constitution since the Judiciary Act of $1789 .^{2}$ Federal courts "ceased to be restricted tribunals of fair dealing between citizens of different states and became the primary and powerful reliances for vindicating every right given by the Constitution, the laws, and treaties of the United States." ${ }^{3}$ The standard view is that the $1875 \mathrm{Act}$, taken together with the 1871 Civil Rights Act, ${ }^{4}$ which provided a private right of action to redress constitutional violations by those acting under color of state law, fundamentally readjusted state and federal judicial power. The modern descendants of these two Reconstruction-era statutes-28 U.S.C. $\S 1331$ and 42 U.S.C. $\$ 1983$ - play a critical role in the way litigants currently raise constitutional issues. Expansive judicial interpretation of the role of federal courts to reach constitutional deprivations under these statutes was provided early in this century by the Lochner ${ }^{5}$ Cour in decisions such as Ex parte Young, ${ }^{6}$ and later by the Warren Court in decisions such as Monroe 1 : Pape. These decisions are themselves associated with "activist" courts, just as the 1871 Civil Rights Act and the 1875 general federal question statute are associated with "activist" Reconstruction Congresses.

Implicit in the emphasis in federal courts scholarship on federal question jurisdiction and the 1871 Civil Rights Act, as well as in their association with

1. See Act of Mar. 3, 1875, ch. 137, § 1, 18 Stal 470,470 (codified as amended al 28 L' S C \$ 1331 (1994)). The Judiciary Act of 1789, ch. 20, I Stat 73. 78. provided for diversily junsdiction in a predecessor to the current provision (28 U.S.C $\$ 1332$ (199.4)), but did not provide lor general Icderal question jurisdiction. See RICHARD H. FALLON ET AL. HART AND WECHSLHA'S THE FEDL:KAL CULKTS AVI THE FEDERAL SYSTEM 29 (4th ed. 1996) thereinafter HART \& WEChSLER] General Iederal question jurisdiction was provided in the $1875 \mathrm{Act}$, which gave federal tnal courts junsdiction "over all suts arising under the Constitution or Laws of the Unuted States "This Act was the predectessor to the current 28 U.S.C. $\$ 1331$ and was part of a Reconstruction-era expansion in federal judicidl power See HakT \& WECHSLER, supra, at 35-36.

2. See HART \& WECHSLER, supra note 1, at 878

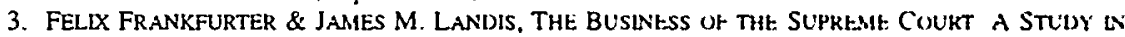
THE FEDERAL Judiclal SYSTEM 65 (1928); see Sieffel v Thompson, +15 U S 452, 46+ (1974) (quulung FRANKFURTER \& LANDIS, supra); Zwickler v. Koota, 389 U S 241. 247 (1967) (same), see also Naltunal Private Truck Council v. Oklahoma Tax Comm'n, 115 S Ct 2351. 2355 (1995) (staltng thut belore 1875. state cours provided the only forum for vindication of many imponuni federal rughis). Felix Franklurter. Distribution of Judicial Power Between United States and State Courts. 13 CokNtLL L Q $499.507-09$ (1928) (stating that the vindication of federal claums was confided intually to state courts) See genteralls Richard H. Fallon, Jr., The Ideologies of Federal Courts Lm. 74 VA L RtV 11.11. 1161.62 11988) (describing the "Nationalist" model of judicial federalism, according to which. "fithe grest turning point occurred during Reconstruction, when Congress radically expanded the scupe of tederal junsuliction. frequently into areas previously reserved to state court" (Iootnote omiticd))

4. Ch. 22, § 1, 17 Stat. 13, 13 (1871) (codified as amended dt 42 US C \$1983 (194)) (providing a cause of action for a constitutional volation under color of stalc law)

5. Lochner v. New York, 198 U.S 45 (1905)

6. 209 U.S. 123 (1908) (holding that junsdiction was appropnste under the lederal questiun statute for a constitutional challenge to a statute regulatung raslroad rales)

7. 365 U.S. 167 (1961) (holding that conduct voldtwe of the Fuurth Amendment cuuld be challenged under 42 U.S.C. $\S 1983$, even if the conduct also molated state law) 
the more transformative eras in state-federal relations, is a belief that at other times-when federal question jurisdiction was either nonexistent or less expansively interpreted-a more state-respecting form of judicial federalism was in place for addressing federal constitutional claims. Indeed, the implication might seem irresistible, given that in the absence of federal causes of action and federal question jurisdiction, constitutional issues would generally come to the federal courts only by way of direct review of state court cases, or when the parties happened to be of diverse citizenship.

This Article challenges this general impression and seeks to show that much of the Supreme Court's development of independent federal rights and remedies took place without reliance on either federal question jurisdiction or statutes such as § 1983, but rather under the rubric of diversity jurisdiction. Throughout the nineteenth century, both before and after Reconstruction, the Court saw diversity jurisdiction as an appropriate vehicle to raise federal questions, sometimes providing an expansive scope to diversity explicitly to accommodate this use of it. The modern emphasis on the development of federal question jurisdiction and $\S 1983$ can therefore be seen as a version of winners' history ${ }^{8}$ that attributes exaggerated historical significance to legislation that is now the dominant means for raising constitutional issues. If, however, continuity exists between the earlier use of diversity and the later use of federal question jurisdiction to redress unconstitutional state action, then a more complete history should also include an account of the use of diversity, in both law and equity, as a form of federal question jurisdiction.

Although the use of diversity to develop a general commercial law under the regime of Swift $v$. Tyson ${ }^{9}$ has received substantial scholarly attention, ${ }^{10}$ its use as a vehicle for raising constitutional issues or other federal questions has received little comment. ${ }^{11}$ The attention to private law in diversity is understandable, because federal court activism in this area might fairly be

8. Cf. L.A. Powe, Jr., Rehearsal for Substantive Due Process: The Municipal Bond Cases, 53 Tвx. L. REv. 738, 738 (1975) (noting that the few cases decided between 1868 and 1890 touching on substantive due process have been thoroughly analyzed because of the later ascendancy of due process).

9. 41 U.S. (16 Pet.) 1 (1842). Swift interpreted the Rules of Decision Act, Judiciary Act of 1789, ch. $20, \S 34,1$ Stat. 73,92 (codified as amended at 28 U.S.C. $\S 1652$ (1994)), as providing that the federal courts in diversity were to apply state law as to matters of a local nature, and were to apply general common law as to matters of general concern, such as matters of commercial law. See infra notes $42-43$ and accompanying text. The decision was overtumed by Erie Railroad Co. v. Tompkins, 304 U.S. 64 (1938), which held that state common and statutory law would apply in diversity.

10. See Tony Freyer, Harmony \& Dissonance: The SwIFT \& ERIE Cases in ambrican FEDERALISM 156 (1981) (discussing Swift as a response to the "uncertainty in state law" and to "erratic local prejudice," meant to reduce the costs of interstate trade and to aid economic development); MORTON J. HoRWITZ, THE TRANSFormation of AMERICAN LAW, 1780-1860, at 220-52 (1992) (seeing Swift less as representing a declaratory theory of law and more as an attempt to impose a procommercial legal order on unwilling states); HERBERT HOVENKAMP, ENTERPRISE AND AMERICAN LAW 1836-1937, at 83-89 (1991) (seeing general common law as expressing federal courts' bias against state regulation); see also infra notcs $37-45$ and accompanying text (discussing general common law).

11. For an account of the scholarly debate on the initial impetus of diversity, see infra notes $29-36$ and accompanying text. 
criticized as improperly encroaching on the lawmaking role of state courts and legislatures, especially in light of modern-era decisions such as Erie Railroad Co. v. Tompkins ${ }^{12}$ that severely limited the common-lawmaking powers of the federal courts. By contrast, in deciding federal questions and constitutional issues, the federal courts were operating in an area of conceded federal competency, even when the basis of subject matter jurisdiction was diversity rather than federal question.

The presumptive propriety of federal cours' deciding federal issues, however, may have led to a modern underappreciation of the extent to which the Supreme Court saw the resolution of such issues as one of the defining purposes of diversity jurisdiction, and of the extent to which the federal diversity courts early on developed independent federal rights and remedies for constitutional violations. This role of diversity as a mechanism for the administration of independent federal rights and remedies shows that the landmarks in the study of constitutional remedies, such as the $1875 \mathrm{Act}$ and Ex parte Young, ${ }^{13}$ did not fundamentally alter the role of the federal courts so much as they gradually changed the labels under which litigants continued to do what they had done in the past. This continuity arguably reinforces the legitimacy of "activist" Supreme Courts' expanding the use of federal question jurisdiction and $\S 1983$, insofar as it reflects a historically settled consensus that the federal courts should administer a federalized set of rights and remedies for federal constitutional rights.

Part I of this Article explores the Supreme Court's use of diversity jurisdiction as a substitute for federal question jurisdiction. It shows how the Court interpreted the diversity jurisdiction broadly to accommodate cases raising federal questions and particularly constitutional issues. At various times, the Court permitted parties to avoid the strictures of diversity by expanding the categories of those who might complain of unlawful state action. The Court thus made it easier for out-of-state citizens to bring constitutional challenges through claim assignments, ${ }^{14}$ shareholder derivative actions, ${ }^{15}$ and other devices. ${ }^{16}$

Part I also explores the sources of law in cases raising constitutional issues that originated in the diversity jurisdiction of federal trial courts. It has sometimes been supposed that in diversity actions against state officers for their wrongful acts, federal courts merely interjected federal law "interstitially" into state law causes of action and thus deferred more to state law than was

12. 304 U.S. 64 (1938).

13. 209 U.S. 123 (1908).

14. See, e.g., Deshler v. Dodge, 57 U.S. (16 How.) 622 (1853). discussed infra nules 69-72. 159-16-4. 293 and accompanying text.

15. See, e.g., Dodge v. Woolsey, 59 U.S. (18 How) 331 (1855). discussed infra nules 64.68 and accompanying text.

16. See, e.g., Reagan v. Farmers' Loan \& Trust Co. 154 U S 362 (1894), disctussed infra nutes 148. 150 and accompanying text. 
later the case when implied constitutional rights of action and the modern $\S$ 1983 suit became available. ${ }^{17}$ Under this traditional view, state law typically would supply the basis for a plaintiff's claim and for the officer's defense. The Federal Constitution would be relied on only to negate the officer's claim of authority under state law. ${ }^{18}$ This Article, however, concludes that the federal diversity courts did not closely imitate state courts in providing remedial rights ${ }^{19}$ in suits against state officials, either in actions at law or in suits in equity. Rather, these older diversity-based federal question cases more closely resembled modern implied constitutional rights of action and $\S 1983$ cases than modern federal courts scholars have supposed.

The remainder of the Article ties the history of constitutional remedies in diversity to the development of constitutional remedies more generally. While Part I shows the development of constitutional remedies in federal courts under the diversity jurisdiction, Part II shows the extent to which the Supreme Court on direct review of state court decisions forced state courts to provide remedies for constitutional harms. It concludes that federal law was indeed genuinely interstitial to state law on direct review of cases raising federal questions in state courts, as distinguished from diversity actions raising federal questions. ${ }^{20}$ This meant that the Supreme Court ordinarily deferred to state courts when it came to the remedial framework in which federal issues would be decided. Nevertheless, in the nineteenth century, the Court occasionally forced remedies on the state courts in lawsuits that sought redress for trespasses committed by state officials acting under unconstitutional state laws. Such remedy forcing suggests that there may have existed a common law baseline of remedies against governmental officials for their illegal behavior that state law could not constitutionally abrogate.

Part III then attempts to show how the two threads of federal court constitutional litigation in diversity and compulsory state court constitutional cases-neither of which depended on authorization from state law-came together to form the framework of modern constitutionally compelled remedies. Part III first traces the emergence of nondiversity federal question constitutional cases in nineteenth-century Contracts Clause litigation. While it

17. See Wheeldin v. Whecler, 373 U.S. 647, 652 (1963); Henry M. Hart, Jr., The Relations Benveen State and Federal Law, 54 ColuM. L. REV 489, 524 (1954) (stating that federal question cases derived from state law trespass actions that contained federal elements); see also Richard H. Fallon, Jr., Some Confusions About Due Process, Judicial Review, and Constitutional Remedies, 93 CoLUM. L. Rkv. 309, 353-54 (1993) (characterizing Hart, supra, at 495-98, as presenting the traditional view that saw "federal law as looming in the background, seldom displacing state law, but available to remedy its deficiencies on an 'interstitial' basis"). For additional discussion of Hart's views, see infra note 116.

18. See Hart, supra note 17 , at 523-24.

19. For an explanation of the term "remedial rights," see infra note 119.

20. It is possible that the traditional view that federal law was interstitial to state law is based primarily on the premise that constitutional issues would arise in state courts rather than federal courts. Nevertheless, it would seem that the traditional view also assumed that federal law was interstitial to state law in federal courts as well. See Hart, supra note 17, at 524. Hart, however, was clearly aware that general common law rather than state law alone might apply in federal court. See infra note 116. 
was forcing trespass remedies on state courts to redress official action taken under unconstitutional statutes (and entertaining the already well-established diversity action to redress an officer's trespass in reliance on an unconstitutional state statute), the Supreme Cour also concluded that such trespass actions brought in federal court "arose under" federal law for purposes of the 1875 jurisdiction statute.

These contemporaneous events shed light on the obscure but common origins of compelled remedies in state courts, diversity actuons raising constitutional issues, and federal question constitutional cases. All three were grounded in a sense that trespass actions to redress deliberate invasions by government officers were, at some level, constitutionally compelled-whether an action was brought in state or federal cour. Part III then illustrates the operation of this three-track remedial pattern for constitutional violations (mandatory trespass-based actions in state court, along with diversity and federal question cases in federal court) by focusing on due process challenges to rate regulation and constitutional challenges to illegal laxation prior to the Tax Injunction Act of 1937. ${ }^{21}$

Finally, Part IV considers the contemporary relevance of the development of constitutionally compelled remedies to problems in modern federal courts jurisprudence. First, it evaluates claims by modern scholars and Justices that sovereign immunity does not bar actions against the state in state courts.": This Article concludes that from the perspective of legal history, such scholars are both right and wrong-wrong in that, absent a state's consent, the Supreme Court historically did not require a state to be amenable to suit in its own name in its own courts, but right insofar as the Court was prepared to force a common law remedy against an individual state officer to remedy constitutional wrongdoing.

Second, Part IV considers the relevance of the historical development of constitutionally compelled remedies to the line of cases associated with Parratt $v$. Taylor. ${ }^{23}$ In these decisions, the Court concluded that many official deprivations of liberty and property are not redressable in federal trial courts. The historical record developed in this Article suggests that the Court's approach in Parratt may be well-founded. On the one hand, the record appears to support an inference that a trespass remedy for government illegality-even illegality under state law alone-may, at some level, be constitutionally

21. 28 U.S.C. $\$ 1341$ (1994). Subsection III C 4 also explores the suspenston of the tradition of tederal question damages actions.

22. See, e.g., Henry Paul Monaghan, The Soveretgn Immumun "Exception." 110 Hakv L RFv I02. 122 (1996) (stating that states are compelled to hear suts aganst them for violution of federal nghis)

23. 451 U.S. 527 (1981). In Parrant and later cases the Coun indicsted that it would nut consider must random and unauthorized tons by government officrals (which do not mplicale a violdtion of the Bill of Rights or other constitutional guarantees evoking heightened scrutuny) to be depnyuttons of Itbeny or propery under the Due Process Clause of the Fourteenth Amendment See infra note $3 \%$ Such cases thus typically cannot be brought as $\$ 1983$ actions in federal courts 
compelled. On the other hand, absent a distinct federal issue in addition to the official's trespass-such as the unconstitutionality of the state statute under which the officer acted-federal jurisdiction was historically unavailable for such trespasses. While the Court had read various congressional jurisdictional provisions so as to enable federal courts to decide federal questions, the Court had not treated a federal question as present absent a claim with a clear connection to a specific federal statutory or constitutional provision. Thus, despite the constitutional compulsion for a system of adequate remedies in state courts for governmental trespass, neither a simple governmental trespass nor the failure to remedy that trespass in an individual case should be seen as presenting substantial federal issues for direct review or original jurisdiction.

\section{Diversity JuRISDICTION AND FEDERAL Questions}

For a statute that supposedly marked a revolution in judicial federalism, the passage of the general federal question statute oddly sparked little debate. ${ }^{24}$ Although there were complaints in Congress for the next twenty-five years about the crowded dockets of federal courts and the diminution of state powers effected by expansive federal jurisdiction, congressional proposals were primarily directed to reducing diversity, not federal question, jurisdiction. ${ }^{25}$

There may be a number of reasons that the 1875 Act seemed less of a decisive moment for judicial federalism at the time of its passage than it does now. The mandatory Supreme Court review under section 25 of the Judiciary Act of 1789 for denials of federal rights in state courts ${ }^{26}$ may have blunted the perceived impact of the new provisions for original jurisdiction in the lower federal courts. ${ }^{27}$ What is more, many federally created causes of action-including the 1871 Civil Rights Act-had their own jurisdictional provisions. ${ }^{28}$ But an additional reason for the lack of attention to the federal

24. See James H. Chadbourn \& A. Leo Levin, Original Jurisdiction of Federal Questions, 90 U. PA. L. REV. 639; 644 \& n.34 (1942) (noting the lack of discussion of federal question jurisdiction in legal periodicals); $c f$. FRANKFURTER \& LANDIS, supra note 3, at 66-67 (noting that the bill originated as one to allow removal on less than complete diversity). See generally Ray Forrester, The Nature of a "Federal Question," 16 TUL. L. REV. 362 (1942) (indicating that confusion remained at the time as to when a case arose under federal law for purposes of general federal question jurisdiction).

25. See FRANKFURTER \& LANDIS, supra note 3, at 89-90; TONY ALLEN FREYER, FORUMS Or ORDER: THE FEDERAL COURTS AND Business IN AMERICAN History 130-36 (1979); Michael G. Collins, The Unhappy History of Federal Question Removal, 71 IOWA L. REV. 717, 743-45 (1986).

26. Ch. $20, \S 25,1$ Stat. $73,85-87$.

27. On direct review, however, adequate state law grounds to support a judgment might preclude review, as could the requirement that the denial of the federal right appear on the face of the record. See infra notes 78-86 and accompanying text. Factual questions could often be unreviewable as well.

28. See, e.g., Act of Apr. 20, 1871, ch. 22, §6,17 Stat. 13, 15 (codified as amended at 28 U.S.C. $\S$ 1343(a)(3) (1994)); David E. Engdahl, Federal Question Jurisdiction Under the 1789 Judiciary Act, 14 OKLA. CITY U. L. REV. 521, 532-34 (1989) (noting that in earlier years, Congress routinely gave federal courts jurisdiction over suits under new statutes). Given the narrow scope initially attributed to $\$ 1983$. however, a fair amount of federal constitutional litigation under the Contracts and Commerce Clauses could not have been brought under the 1871 Act. See Michael G. Collins, "Economic Rights," Implied Constitutional Actions, and the Scope of Section 1983, 77 GEO. L.J. 1493, 1499-1 506 (1989) (discussing 
question statute may have been that litigation of federal constitutional issues through diversity jurisdiction was sufficiently commonplace that the advent of federal question jurisdiction was not perceived to be a particularly dramatic step. While undoubtedly the 1875 Act expanded federal trial cour jurisdiction, the expansion was into a field where federal cours were already actively operating.

\section{A. "General Law" and Diversity}

The use of diversity to raise federal questions may be set in context by two major strands of scholarship on the history of diversity. One strand was a debate that arose earlier in this century as to the initial impetus for the provision of diversity jurisdiction in the Constitution and the Judiciary Act of 1789. Another strand focused on the use of diversity to promote cornmerce through the use of the general common law.

\section{The Origins of Diversity Jurisdiction}

The debate as to the impetus for diversity centered on whether local prejudice against out-of-state citizens-the usual justification for the availability of a federal forum in diversity - in fact existed, particularly in state courts. Henry Friendly, seconded by Felix Frankfurter, sought to minimize claims that local prejudice had been a serious problem at the time of the framing of the Constitution or the Judiciary Act of 1789..$^{2 y}$ Instead, Friendly saw the desire to protect creditors from legislation favorable to debtors as the more significant motivation for the original constitutional and statutory grants of diversity. ${ }^{30}$

Others have criticized the attempt to minimize the role of local prejudice. Wythe Holt, for example, explored the historical evidence of local prejudice at length, and concluded that federal courts were created largely because state courts could not be trusted to handle out-of-state and alien creditors' suits against local debtors. ${ }^{31}$ Others have also seen local prejudice as a significant problem and further observed that the local prejudice rationale should not be tested merely by reference to state cour judicial decisions but should also include consideration of state legislation such as debtor relief laws. ${ }^{32}$ Still

narrow interpretations of $\S 1983$ ).

29. See Henry J. Friendly, The Histonc Basis of Diversing Jurisdiction. 41 HakV L ReV 483.493-97. 501 (1928) (minimizing claims that local coun prejudice was a problem at the tume of the traming of Article III); accord Frankfuner, supra note 3, at 520.

30. See Friendly, supra note 29, at 495-97.

31. See Wythe Holt, "To Establish Justice": Poliucs. the Judician Acr of 1789, and the Ins ention of the Federal Courts, 1989 DuKE L.J. 1421, 1455-58 (concluding that the natsonal coun system was created in large part because state courts could not be trusted to handle creditors' suits agdinst debtors)

32. See, e.g., Hessel E. Yniema \& George H Jaffin. Preliminang Analisis of Concurrent Jurisdiction. 
others have found merit to arguments on both sides of the judicial prejudice debate..$^{33}$

All sides of the prejudice argument, however, apparently agreed that concern over state debtor relief legislation was an impetus to diversity. ${ }^{\mathbf{3 4}}$ Presumably they also agreed that creditors seeking to avoid such legislation would frequently be aliens or out-of-staters; otherwise, the provision of diversity jurisdiction could not address the problem. Debtor relief legislation, moreover, could violate the Contracts Clause, ${ }^{35}$ which outlaws legislative attempts to impair existing contractual relationships retroactively. Insofar as fears of state debtor relief legislation motivated the provision of diversity jurisdiction, the use of diversity to raise federal constitutional issues, as described more fully below, was consistent with the original impetus for providing such jurisdiction. ${ }^{36}$ Although this Article focuses on the actual use of diversity rather than the Framers' intent in providing for it, the use of diversity to raise federal issues apparently did not diverge from their original intent.

\section{Use of Diversity to Promote Commercial Interests}

Most of the scholarly treatments respecting the historical use of diversity jurisdiction have focused on the federal courts' development of the general common law. It is a familiar story that in the era of Swift v. Tyson, ${ }^{37}$ the Supreme Court interpreted the grant of diversity jurisdiction and the Rules of

79 U. PA. L. REV. 869, 873-78 \& n.13 (1931) (questioning Friendly's minimization of local prejudice and seeing local prejudice as tied to concerns about state legislation, such as debtor relief laws).

33. See John P. Frank, Historical Bases of the Federal Judicial System, 13 J.L. \& CoNTEMP. PROBS. 3, 22-28 (1948) (finding merit to both positions and identifying some evidence of local bias); James William Moore \& Donald Weckstein, Diversity Jurisdiction: Past, Present, and Future, 43 TEx. L. REV. 1, 15-17 (1964) (stating that it is probably more accurate to say that it was the fear of local prejudice, rather than actual prejudice, that the Framers sought to guard against); see also ROBERT N. CLINTON BT AL., FEDERAL COURTS-THEORY AND PRACTICE 416 (1996) ("In short, some federalists supporting diversity jurisdiction expected it to provide not only a neutral forum, but also a more neutral, less prodebtor, law than existed at the time in some of the states . . . .").

34. See, e.g., Frankfurter, supra note 3, at 520.

35. U.S. CONST. art. I, § 10, cl. 1.

36. As Yntema and Jaffin write:

It is true, for instance, that glaring difficulties such as those arising from land grants and papertender acts, were specifically provided for in the Constitution; the diversity jurisdiction was one of several granted to the federal courts to guarantee "equal privileges and immunities" and to assure the enforcement of the not unrelated constitutional restrictions upon the states in those cases which had been most productive of disharmony, typically involving the interest of aliens or of the citizens of more than one state.

Yntema \& Jaffin, supra note 32, at 876 n.13; cf. Engdahl, supra note 28, at 521-22, 530, 532-33 (arguing that various provisions of the Judiciary Act of 1789 effectively gave federal courts jurisdiction over all cases that could have been contemplated as "federal question" cases). Professor Engdahl notes, for example, that alienage jurisdiction would cover many cases of treaty rights and that jurisdiction over penalties and forfeitures under laws of the United States would have included suits between private parties under federal laws. See Engdahl, supra note 28, at 529-33.

37. 41 U.S. (16 Pet.) 1 (1842). 
Decision $\mathrm{Act}^{38}$ as authorizing the federal courts to develop an independent private law. ${ }^{39}$ For example, the federal courts applied the general common law principle of negotiability of commercial paper that frequently differed from both state common law and statute law. ${ }^{20}$ Indeed, Swift itself was such a negotiability case. ${ }^{41}$ Although Swift was later read as commanding federal court adherence to a state's statutes (as opposed to state common law), recent scholarship supports a reading of Swift that allowed federal courts to ignore both state statutes and common law in areas that were "general" rather than "local."42 Scholars attribute the Court's willingness to engage in such common-lawmaking to its interest in promoting the interstate economy, ${ }^{33}$ to a conviction that general law was the appropriate choice of law for actions involving citizens of different states, ${ }^{44}$ and to a belief that the application of state law might exceed the territorial limits of state power in such cases."

The Court's belief in the propriety of applying uniform general law norms to commercial transactions apparently influenced it to interpret the federal courts' diversity jurisdiction expansively when such transactions were involved. ${ }^{46}$ For example, the reach of the Court's decisions favoring

38. Judiciary Act of 1789 , ch. $20, \S 34,1$ Stat. 73.92 (codified as amended at 28 U S C $\$ 1652$ (1994)) ("[T]he laws of the several states, except where the constutution, treatues or statutes of the Untied States shall otherwise require or provide, shall be regarded as rules of decision in trals al common law in the courts of the United States in cases where they apply.").

39. See FREYER, supra note 10 , at 58 (stating that, by the 1880 s, general law included 26 distunet doctrines). cases).

40. See FREYER, supra note 25, at 46; HORWTI., supra note 10. at 220-52 (discussing negotiability

41. In Swift, the Court held that under general commercial law as applicable to negouable instruments. a preexisting debt was valuable consideration, thereby rejecung a defense urged under New York law See 41 U.S. (16 Pet.) at 15-19.

42. See, e.g., William A. Fletcher, The General Comnon Low and Section 34 of the Judiciany Act of 1789: The Example of Marine Insurance, $97 \mathrm{HARV}$. L. REV. 1513. 1554 (1984) (noung that fecteral couns would ignore state statutes in marine insurance cases); see also Bradford $\mathrm{R}$ Clark. Federal Conynon Lam A Structural Reinterpretation, 144 U. PA. L. REV. 1245. 1279.92 (1996) (statung that the local versus general law distinction was grounded in the distunction between lex loct (local law) and jus gentum (the law of nations)).

43. See, e.g., FREYER, supra note 10, at 156 (discussing the Couri's use of general law to promule economic development); HoRwTZ, supra note 10. at 250 (statung that Swift may be seen as an altempt to impose a procommercial national legal order on unwilling states); see also FREYER. supra note 25, al $x i x$. $3-38,46$ (discussing the use of federal jurisdiction, the corporate fiction, and general common law to blunt state attacks on corporations and to establish unform corporate junsprudence administered in federal courts).

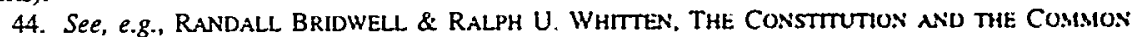
LAW 4-5, 61-97 (1977) (concluding that Swifi's general common law system was designed to vindicate the legitimate expectations of paries to disputes).

45. Cf., e.g., Hovenkamp, supra note 10, at $87-89$ (stating that Justuce Story saw general law as necessary partly to restrict extraterritorial application of state baw). Fletcher. supra note 42. all 1 S14 (staling that $\$ 34$ embodied a lex loci principle that had no applicauon to general law)

46. See, e.g., Dudley O. McGovney, A Supreme Court Ficrion: Corporations in the Diverse Cittzenshup Jurisdiction of the Federal Courts, 56 HARV. L. REV 853, 883-85 (1943) (atunbutung expanstons of diversity to a desire to apply general common law to protect commercial and corporale interests). see also GERARD CARL HENDERSON, THE POSITION OF FOREIGN CORPORATIONS IN AMERICAN CONSTITUTIONAL LAW 72-74 (1918) (discussing the diversity rules for corporations incorporaled in more than one state). HoRwm, supra note 10 , at $250-51$ (noting that Justice Story altemplad to advance commeretal interests 
negotiability might have been limited by the Assignee Clause of the Judiciary Act of $1789,{ }^{47}$ which required federal courts to look to the citizenship of the original parties on promissory notes to determine diversity and required them to disregard later assignments. ${ }^{48}$ Thus in Sheldon $v$. Sill, ${ }^{49}$ a New York assignee of a mortgage could not invoke diversity jurisdiction against a Michigan mortgagor because the original mortgagee had been a Michigan citizen. The Assignee Clause had an exception, however, for "foreign bills of exchange," 50 an exception which the Court read broadly, thereby allowing for diversity in many interstate debt cases even when the originally contracting parties were citizens of the same state. ${ }^{51}$

In addition, the Court expanded the ability of corporations to sue and be sued in diversity by a series of interpretations of corporate citizenship. ${ }^{52}$ Under Chief Justice Marshall, the Court had said that citizenship of a corporation depended on that of its shareholders. ${ }^{53}$ Such a doctrine might have impeded a corporation's ability to obtain a federal diversity forum because shareholders might be citizens of several states and thus potentially

by an expansion of federal jurisdiction, such as by holding that all disputes involving marine insurance contracts were within federal jurisdiction).

47. Ch. 20, §§ 11-12, 1 Stat. 73, 78, 79.

48. Congress broadened exceptions to the Assignee Clause in 1875, see Act of Mar. 3, 1875, ch. 137 , $\S 1,18$ Stat. 470,470 , but narrowed them again in acts of 1887 and 1888, see Act of Mar. 3, 1887, ch. $373, \S 1,24$ Stat. 552, 552-53; Act of Aug. 13, 1888, ch. 866, § 1, 25 Stat. 433, 433-34, discussed in Moore \& Weckstein, supra note 33, at $8-9$ \& $\mathrm{nn} .42,51$. The 1948 revisions replaced the Assignee Clause with a more general provision denying jurisdiction "of a civil action in which any party, by assignment or otherwise, has been improperly or collusively made or joined to invoke the jurisdiction of such court." 28 U.S.C. § 1359 (1994), discussed in Moore \& Weckstein, supra note 33, at 11 \& n.71.

49. 49 U.S. ( 8 How.) 441 (1850). The suit was to recover the amount of a bond and mortgage. Suits only for foreclosure, however, could be brought without regard to the citizenship of the initial partics. See infra note 72 .

50. $§ 11,1$ Stat. at 79 .

51. A bill of exchange involved three parties: a drawer, who issued an order on a drawee to pay a certain amount; a drawee, who would become liable to pay the amount (usually at a future date) if he "accepted" the bill; and a payee. See HovenKaMP, supra note 10, at 84 . The bills were generally considered negotiable, such that the payee could endorse the bill to a fourth party who could present the bill to the drawee on maturity as the initial payee could have. See id. A foreign bill of exchange initially meant that the drawer and drawee were citizens of different countries. The Supreme Court interpreted the exception to the Assignee Clause for foreign bills of exchange to include bills where the initial drawer and drawee were from different states. See id.; see also Buckner v. Finley, 27 U.S. (2 Pet.) 586, 590-93 (1829), discussed in HOVENKAMP, supra note 10, at 85-86 \& n.21.

52. See FREYER, supra note 25, at 47, 92 (discussing the Taney Courn's upholding of nonresident corporations' right to sue in federal court); McGovney, supra note 46, at 865-70 (discussing the Court's use of various fictions to allow corporations access to federal courts). There were some exceptions to the Court's expansive allowance of corporate diversity. For example, the Court for a time upheld state statutes that conditioned doing business in the state on not removing cases to federal courts. Such statutes werc enforceable by expulsion from the state but not by remand of a case removed to federal court. See Doyle v. Continental Ins. Co., 94 U.S. 535 (1876), discussed in HENDERSON, supra note 46, at 106-07, 135-37; Harry N. Scheiber, Federalism and the American Economic Order, 1789.1910, 10 L. \& Soc'Y RgV. 57. 106-08 (1975).

53. See Bank of the United States v. Deveaux, 9 U.S. (5 Cranch) 37, $51-52$ (1809) (upholding jurisdiction on the basis of an allegation that the shareholders were all from Pennsylvania); see also McGovney, supra note 46 , at $865-70$ (characterizing Deveaux as broadening federal jurisdiction as much as was consistent with the Court's view that a corporation itself was not a citizen). 
defeat diversity against an opposing party under the Court's complete diversity requirement. $^{54}$ The Taney Court, however, soon created an irrebuttable presumption that all shareholders of a corporation were citizens of the state of incorporation. ${ }^{55}$ Thus, diversity became a simpler proposition for the corporate litigant.

\section{B. Diversity's Accommodation of Federal Issues}

Diversity and the Court's expansive interpretations of it to protect commerce and capital tended to sweep in many cases raising federal constitutional issues. Parties suing in diversity on debt claims, for example, might raise issues of the constitutionality of state debtor relief legislation, a use of diversity apparently contemplated by the Constitution's Framers. ${ }^{56}$ Such a case might originate as a suit on a debt by the out-of-state creditor in which the debtor would defend his nonpayment by reliance on state debtor relief laws. The creditor in reply would claim the statute violated the Contracts Clause. ${ }^{57}$ The Constitution, although relevant to judicial proceedings primarily when the validity of a statute was in question, reflected concerns with the protection of contracts and interstate commerce that were similar to those animating the deployment of the general common law in federal courts. ${ }^{\text {ss }}$

Even beyond this link between commercial cases brought in diversity and constitutional claims, the Court self-consciously gave diversity an expansive

54. See Strawbridge v. Curtiss, 7 U.S. (3 Cranch) 267 (1806) (establishing the requirement of complete diversity).

55. See Marshall v. Baltimore \& O.R.R., 57 U S (16 How) 314 (1853) (basing diverstly for corporations on a presumption that all shareholders resided in the state of incorporation). Loutsville. $C$ \& C.R.R. v. Letson, 43 U.S. (2 How.) 497 (1844) (indicaung that a corporatuon was capable of being treated as a citizen of the state of incorporation for diversity purposes), see also Ohio \& Miss R $R$ V Whecler. 66 U.S. (1 Black) 286, 296 (1861) (characterizing Letson as based on the presumpuon about the cilizenshup of shareholders). See generally. HovENKAMP, supra note 10, al 19 (tying the nse of substantuve due process to the movement to conceptualize the corporation as a person, which onginated in Jusuce Taney's diverstly jurisdiction decisions and became fully developed after the Couri's holding in Santa Clara County $y$ Southem Pacific Railroad, 118 U.S. 394, 396 (1886), that a corporation is a person for purposes of the Fourteenth Amendment); McGovney, supra note 46, at $882-86$ (characterizing counsel's argument in Letson as a plea "to expand the jurisdiction of the federal courts to save more and more corporations from the supposed injustices of the state courts").

56. See Yntema \& Jaffin, supra note 32, at $879 \mathrm{n.17}$ (suggesting that a local prejudice rationale for the provision of diversity would have included concems over unconstututuonal state legislation); see also sources cited supra note 33.

57. See, e.g., Ogden v. Saunders, 25 U.S. (12 Wheat.) 213 (1827) (deciding a Contracts Clause question in a diversity suit on a bill of exchange in which the defendant pleaded discharge under a New York insolvency law).

58. While the Court desired to allow corporations, and corporations with federal questuun cases, unto federal coun, the Court's stance was not simply procorporation or proproperty As described by Professor Hovenkamp, the Court moved away from the carly mercantulsst vicws of the Marshill Coun toward the "classical" economic views that prevailed thereafter. While the classical views were prodevelopment, their central tenet was that the most effective development would occur by leaving businesses free not only of regulation, but also of subsidies. See HovenkaMp, supra note 10, at 11 Thus, the Taney Coun and later Courts read grants of monopoly privileges in corporate chanters very narrowly. and subsequent courts continued to undermine notions that corporate chaners granted vested privileges See td at 25.35 
reading to facilitate the federal courts' resolution of federal constitutional questions. This was particularly evident in Contracts Clause cases alleging that state legislatures had abrogated promises made in corporate charters. At the time, corporations were often incorporated under special legislative charters, rather than under the general incorporation statutes that later came into widespread use. ${ }^{59}$ In a line of cases starting with the Dartmouth College Case ${ }^{60}$ the Supreme Court held that a state violated the Contracts Clause if it attempted legislatively to withdraw special privileges granted by a charter, at least if the charter contained explicit grants and lacked revocability provisions. ${ }^{61}$

Although the charter abrogation cases proved a lively source of constitutional litigation in the antebellum federal courts, they might, at first glance, have looked like poor candidates for diversity jurisdiction. As noted above, ${ }^{62}$ the Court eventually established a conclusive presumption that all corporate shareholders resided in the state of incorporation. This presumption-normally of assistance to corporations in establishing diversity-would seem to defeat jurisdiction when a corporation alleged a legislative impairment of its corporate charter by the very state that had chartered the corporation in the first place. This was because a corporation challenging such an abrogation would normally be suing a defendant official in its own state of incorporation-for example, suing a tax collector who seized money for taxes that were beyond a maximum rate promised in a charter. ${ }^{63}$ The presumption that all shareholders of the plaintiff corporation resided in the chartering state would therefore appear to have deprived the federal courts of the basis for diversity jurisdiction.

59. See FREYER, supra note 25, at 101; HOVENKAMP, supra note 10, at 36. See generally Henry N. Butler, Nineteenth-Century Jurisdictional Competition in the Granting of Corporate Privileges, 14 J. LEOAL STUD. 129 (1985) (discussing the reasons that legislatures abandoned the granting of special charters).

60. Trustees of Dartmouth College v. Woodward, 17 U.S. (4 Wheat.) 518 (1819) (holding that a corporate charter is a contract protected by the Contracts Clause); see also Fletcher v. Peck, 10 U.S. (6 Cranch) 87 (1810) (holding that the repeal of a statute confirming title to land impaired the obligation of contract). See generally DAVID CURRIE, THE CONSTITUTION IN THE SUPREME COURT 1789-1888, at 141-45 (1985) (discussing the Dartmouth College Case); BENIAMIN FLETCHER WRIOHT, JR., THB CONTRACTS ClAuSE OF THE CONSTITUTION at xiii (1938) (surveying Contracts Clause cases and noting that the Contracts Clause was the constitutional clause that was the most frequent basis for Supreme Court decisions in the 19 th century).

61. See generally WRIGHT, supra note 60 , at 62-63, 84 (discussing the Tancy Court's strict construction of charters); id. at 84 (discussing reservation clauses).

62. See supra note 55 and accompanying text.

63. See, e.g., Jefferson Branch Bank v. Skelly, 66 U.S. (1 Black) 436 (1861). Contracts Clausc cases involving the abrogation of government contracts could also be brought by one company claiming monopoly privileges against a subsequently chartered competitor. See, e.g., Bridge Proprietors v. Hoboken Co., 68 U.S. (1 Wall.) 116 (1863) (finding no Contracts Clause violation in a case between an old and a new bridge company); Charles River Bridge v. Warren Bridge, 36 U.S. (11 Pet.) 420 (1837). Many of these cases, including the Charles River Bridge case, originated in state courts, but some plaintiffs were able to use the diversity derivative action discussed infra notes 94-104 and accompanying text. See, e.g., Greenwood v. Freight Co., 105 U.S. 13, 14 (1881) (allowing a derivative action against a competing business and various other defendants). 
The Supreme Court, however, permitted end runs around its own diversity decisions, which had presumed that shareholders resided in the state of incorporation. In Dodge v. Woolsey, ${ }^{64}$ for example, an out-of-state shareholder of an Ohio bank sued an Ohio government official to enjoin the threatened forcible collection of a tax at a rate higher than that promised under an 1845 bank chartering statute. Although the suit was essentially one between an instate bank and a state official, the Court held that the federal courts had diversity jurisdiction in this early shareholder derivative action. The dissent sensibly objected that diversity should be unavailable given the conclusive presumption that all shareholders resided in the state of incorporation and the suit was against the state official, a citizen of that same state. ${ }^{\text {as }}$ The majority nevertheless treated the shareholder's citizenship for the derivative suit as his actual citizenship rather than using the presumption of citizenship in the state of incorporation. The Court reasoned that the case was appropriate for federal jurisdiction because it was brought by a "citizen of the United States, residing in Connecticut, having a large pecuniary interest in a bank in Ohio, because the corporation's board would not test the validity of the tax despite agreeing with the shareholder that the tax law was unconstitutional. ${ }^{67}$ The Court thus looked beyond its own corporate-citizenship fiction to the economic and political reality of out-of-state investors' need for the protection of the federal courts. In response to arguments that federal jurisdiction would impinge on state sovereignty, the Court observed that federal jurisdiction was appropriate in cases involving self-executing rights under the Contracts Clause. ${ }^{68}$

It was not only in equity suits such as Woolsey, but also in actions at law that the Court allowed the strictures of diversity to be evaded so as to permit cases presenting federal questions to be heard in federal trial courts. In Deshler v. Dodge $e^{69}$ the Court entertained a diversity replevin action against the state tax collector who had seized bank notes to collect the same state tax that was at issue in Woolsey. Several of the affected Ohio banks had contractually assigned the notes to a New York citizen after the collector seized them. Although the New York plaintiff might have been diverse from the local Ohio

64. 59 U.S. (18 How.) 331 (1855).

65. See id. at 364-65 (Campbell, J., dissentung), see also Hovenkdup. supra note 10. at $1+15$ (remarking that the reasoning of cases that conclustvely presumed all shareholders to reside in the state of incorporation was undermined by Woolsey); McGovney, supra nolc 46. At 889-90 (remarking on Woolsey"s inconsistency with the presumption of shareholder calizenship in the state of incorporation), of Davenport v. Dows, 85 U.S. (18 Wall.) 626 (1873) (remanding the case to require joinder of a corporation as a defendant in a derivative action to enjoin collection of a tax in order to assure that the corporatuon would be bound).

66. Woolsey, 59 U.S. (18 How.) at 356.

67. See id.

68. See id. at $349-50$ (noting that the legislative powers conceded to Congress and the prohibutions in Article I, section 10 upon the states conferred nghis-in the latter cise self-execuling-and that stalles could not be the final arbiters of the Constitution or federal law)

69. 57 U.S. (16 How.) 622 (1853). 
official, the Assignee Clause appeared to disallow a diversity suit by the New York assignee, because the Clause forbade federal jurisdiction unless the suit might have been brought under the diversity jurisdiction if no assignment had been made. And the Ohio assignor-banks clearly could not have sued the Ohio collector on their own in federal court. ${ }^{70}$ Nevertheless, the Court overcame the Assignee Clause objections by reasoning that the Clause was inapplicable to an action for wrongful detention of notes. ${ }^{71}$ The Court supported its conclusion that the Clause was inapplicable to suits to recover specific property (in this case, the notes) with its prior decisions that the Clause did not apply to suits to recover only the possession of mortgaged premises. ${ }^{72}$ The Court's solicitude for violations of the Contracts Clause thus complemented its solicitude for the sanctity of contracts more generally.

\section{The Nonpresumption of Parity}

Woolsey and Deshler suggest that the Court saw the resolution of federal questions as no mere incidental benefit of diversity jurisdiction, but rather as one of its defining purposes. Indeed, the Court was explicit that it was using-even stretching-diversity jurisdiction to reach federal issues. ${ }^{73}$ The Court's expansion of diversity to accommodate federal questions also indicates that there was no strong presumption of parity of state and federal courts for the resolution of federal questions in civil cases. ${ }^{74}$ The Court did not appear to entertain any such presumption even though, under section 25 of the Judiciary Act of 1789, it could review denials of federal rights in state courts, and the Supremacy Clause ${ }^{75}$ would obligate state courts to follow the Supreme Court's federal law decisions. The Woolsey Court found that federal jurisdiction was supported by an allegation that, in response to shareholder demands that corporate directors initiate proceedings on behalf of the corporation to resist the tax, the directors had refused, "in consideration of the

\footnotetext{
70. See id. at 631 .

71. See id.

72. See id. A suit to enforce payment of a debt by the sale of the premises or by decree against the mortgagor would be covered by the Clause. See id.

73. See Woolsey, 59 U.S. (18 How.) at 349 (noting the propriety of federal jurisdiction for vindicating Contracts Clause rights); see also, e.g., Hawes v. Oakland, 104 U.S. 450, 458-59 (1881) (indicating that Woolsey's liberality in making derivative actions available had been motivated by a desire to provide a federal forum for a federal issue). The Court's expansive use of diversity did not go without comment, although the criticism was often directed to the use of federal courts to accommodate business interests. See FREYER, supra note 25, at 26-27 (noting contemporary commentary on merchants' use of federal courts); cf. D.H. Chamberlain, New-Fashioned Receiverships, 10 HARV. L. REV. 139, 141-42, 145-46, 148 (1896) (criticizing the widespread use of federal receiverships at the instance of railroads in the absence of bankruptcy laws); McGovney, supra note 46, at 1227-28 (discussing congressional proposals to limit corporate diversity in the 1880 s); sources cited supra note 25 .

74. See generally Fallon, supra note 3, at 1161 (discussing the parity debate).

75. U.S. CONST. art. VI, cl. 1.
} 
many obstacles in the way of resisting the tax in the state courts." While the Court explicitly declined to cast aspersions on state courts, it considered allegations that the corporation faced impediments in vindicating federal rights in state courts to be supportive of federal equity jurisdiction. ${ }^{n}$

Nonetheless, one scholar has questioned the need for a federal trial forum in Woolsey on the grounds that the Court simultaneously gave relief to several banks by way of its appellate jurisdiction under section $25 .^{78}$ At the time, denials of federal rights in state courts resulted in mandatory review in the Supreme Court. Nondiscretionary review of denials of federal rights in state courts under the Supreme Court's appellate jurisdiction was not, however, an automatic guarantee of a Supreme Cour forum. The Supreme Court might deny review when, because of possible state law grounds, it was uncertain whether a decision on the federal issue had been decisive to the outcome. ${ }^{79}$ In addition, the requirement of section 25 that the federal question appear "on the face of the record" 80 was a significant hurdle to review ${ }^{81}$ prior to the deletion of the requirement in $1867 .^{82}$ Because the Court-at that

76. Woolsey, 59 U.S. (18 How.) at 356 (quoting the allegation of the directors)

77. The Court diplomatically said that "[w]ithout partaking. ourselves, in their unienunty of reltel in the courts of Ohio," id. at 356, the directors' response nevertheless supported the shareholders' sunt in equity by diminishing their confidence in the state cours See ad, see also infra nutes 101-10.4 and accompanying text.

78. See McGovney, supra note 46 , at 892

79. See, e.g., Bank of W. Tenn. v. Cituzens' Bank, 81 U S (14 Wall) 9 (1871) (holding that a section 25 case was not presented where the Louisiana Supreme Coun had relied both on pnor cases and a subsequent state constitutional provision abrogating (ransactions in confederate curnency). Rallroad $\mathrm{Co} r$ Rock, 71 U.S. (4 Wall.) 177. 181 (1866) (denying review, despite the cerufication of the state supreme court, partly because of the possibility that the state court dectsion anvalidating county bunds had been based on a determination of fraud rather than on the Consutution). MIIlls $\vee$ Brown. HI U S (16 Pet) 525 . 527 (1842) (dismissing a writ of error upon concluding that the decision may have been made on other than Contracts Clause grounds); see also infra note 167. See generally Richard A Malasar \& Gregory S Bruch. Procedural Common Law; Federal Jurisdictional Polic): and Abandonunent of the Adequate and Independent State Grounds Doctrine, 86 COLUM. L REV. 1291. 1358-59 (1986) (indicaling that the Court basically had applied an adequate state grounds doctnne pnor to Mluriock s. Cin of Memp/hs. 87 U S (20 Wall.) 590 (1874)). Professors Matasar and Bruch indicate that the Coun between 1875 and 1893 reviewed federal issues even when the judgment could be supponed on state law grounds See ad at 1309.1359-63

80. "But no other error shall be assigned or regarded as a ground of reversal in any such case as aforesaid, than such as appears on the face of the record, and immediately respects the before mentioned questions of validity or construction of the said constutution. ureatues, statules, commisstons, of duthontues in dispute." Judiciary Act of 1789 , ch. 20, $\$ 25,1$ Stat. 73, 86-87, deleted by Act of Feb S. 1867. ch 18. $\$ 2,14$ Stat. 385, 386-87; see Murdock, 87 U.S. (20 Wall) at 595 (statement of the case). 617 (discussing the difference in the statutory provisions, and concluding that the 1867 Act repealed section 2S)

81. See, e.g., Rock, 71 U.S. (4 Wall.) at 180 (stating that a section 25 issue "must appear in the pleadings of the suit, or from the evidence in the course of the tnal, in the instructions asked for. or exceptions taken to the ruling of the cour"); McKinney v Carroll, 37 U S (12 Pel) 66, 70-71 (1838) (stating that it was insufficient for section 25 review that a reviewable issue might have been dexided and that it must be apparent from the record that reviewable issues arose in the coun below and that a decision was actually made thereon); Crowell v. Randell, 35 U S (10 Pet) 368. 392 (1836) (staling that at was not enough to show that a decision on a section 25 issue might have occurred). Charles Warren, Legislative and Judicial Attacks on the Supreme Court of the Unted States. 47 AM L RtV I. 186 n 99 (1913) (statung that between 1789 and 1860 , of 222 cases before the Supreme Coun on writs of error trom state courts. 65 were dismissed as not within the Judiclary Act).

82. See Act of Feb. 5, 1867, §2, 14 Stat. at 386 (deletung the words quoted supra note 80). Sfurdock. 87 U.S. (20 Wall.) at 633 (indicating that in light of the stitutory requsrement's delction. the Court could 
time-would not treat the state courts' opinions as part of the record, ${ }^{83}$ this requirement could prevent review even where federal issues were clearly dispositive of the case. ${ }^{84}$ The Supreme Court's motivation for its deference to state law decisions seemed to be one of adhering to section 25's explicit limitations on Supreme Court appellate jurisdiction. ${ }^{85}$ In addition, strict application of section 25's requirements may have helped to weed out potential appellants who could not legitimately claim denial of a federal right. ${ }^{86}$

What is more, the impact of section 25 review could be limited by the grudging stare decisis effect that the state courts sometimes accorded to Supreme Court decisions. It is no secret that antebellum state courts were resistant to Supreme Court decisions on issues associated with heightened state-federal tension such as the constitutionality of the Bank of the United States ${ }^{87}$ and the enforcement of the fugitive slave laws. ${ }^{88}$ But they were also resistant to certain less celebrated Contracts Clause rulings, ${ }^{89}$ rulings issued regularly until the Due Process Clause took on the constitutional heavy lifting late in the nineteenth century. ${ }^{90}$ The Supreme Court, for example, repeatedly had to rule unconstitutional the same law that it found invalid in Woolsey and Deshler in review of several other Ohio Bank cases following those two decisions. ${ }^{91}$ The advantages of a federal trial were as obvious to litigants with

now look to properly authenticated court opinions to determine if a federal right had been denied, which it had previously done only as to Louisiana cases); see also Philadelphia Fire Ass'n v. New York, 119 U.S. 110,116 (1886) (noting that the Court could look to the opinion of the court below to determine if there was an issue for direct review).

83. This was true even if state procedures treated the opinions as part of the record. The strictness was alleviated by allowing certifications signed by state court chief justices or presiding officers that certain issues were decided. See Murdock, 87 U.S. (20 Wall.) at 633-34.

84. See, e.g., Fisher v. Cockerell, 30 U.S. (5 Pet.) 248 (1831) (dismissing the writ of crror for want of jurisdiction despite the clerk's certification that certain documents read into evidence would have established a federal issue about violation of a Virginia-Kentucky compact); see also Gibson v. Chouteuu. 75 U.S. (8 Wall.) 314 (1868) (refusing to consider a federal question involving a limitations period that was the apparent reason for the state court's reversal of its prior decision, because it did not appear on the face of the record). Aithough Gibson was decided in 1868, it apparently did not apply the 1867 revisions.

85. See supra note 80; see also Rector v. Ashley, 73 U.S. (6 Wall.) 142 (1867) (refusing to dismiss an appeal where the nonfederal ground was in the state courts opinion, but was not on the face of the record for purposes of section 25 ).

86. See Murdock, 87 U.S. (20 Wall.) at 628-29 (noting that many cases were brought to the Supreme Court where the parties' allegation of a federal question was unsupported).

87. See McCulloch v. Maryland, 17 U.S. (4 Wheat.) 316 (1819).

88. See Prigg v. Pennsylvania, 41 U.S. (16 Pet.) 539 (1842).

89. See WRIGHT, supra note 60 , at 83 (noting local opposition to Woolsey); Warren, supra note 81 , at 12-13, 23 (discussing antagonism to section 25 review, including Contracts Clause cases).

90. See HoVENKAMP, supra note 10, at 130 (observing that the "move from charter-based to statutebased rate regulation made application of the Due Process Clause to price regulation all but incvitable").

91. See, e.g., Franklin Branch Bank v. Ohio, 66 U.S. (1 Black) 474 (1861) (reversing the state court's judgment against a defendant bank in a suit for taxes brought by the state attorney general); Jefferson Branch Bank v. Skelly, 66 U.S. (1 Black) 436 (1861) (reversing the state court's judgment against a plaintiff bank that had sued the county treasurer for trespass); see also Wright v. Sill, 67 U.S. (2 Black) 544,545 (1862) (noting in affirming a federal equity decree that whatever differences of opinion had existed in the Court as to the issues had been concluded by prior adjudications). 
federal questions then as they are now ${ }^{92}$ - only the weight of such arguments went to diversity jurisdiction and not to federal question jurisdiction. ${ }^{93}$

\section{Shareholder Actions, Trustees, and Diversity}

Subsequent to Woolsey, litigants availed themselves of the derivative suit

92. Cf. FREYER, supra note 25, at 26-27 (citung 19th-centuny commentany an merchunts prelerence for federal courts). It is difficult for this Arucle to assess the relatuve significance of state versus federal actions for raising constitutional cases in the 19th century. The Conirates Clause was perhaps the must litigated constitutional clause in the 19th century. see WRIGHT. supra note 60, at xil, and the Coun accommodated litigants who brought such clams in diversily The Ohu bank cases. discussed supra nutes 64-91 and accompanying text, and the Virgina Coupon Cases, Jiscussed infra nules 213-229. 247-256 and accompanying text, involved simultaneous federal and state coun litgaltion

Contracts Clause cases based on a slatc's breach of a promise not to lacense a compeung business similarly could arise in both state and federal courts. See supro note 63 Commerce Clause challenges seemed to arise more frequenuy as challenges to state enforcement actions, see infra note 233. which would generally dictate a state forum. See generally Ann Woolhandler \& Michacl G Collins. State Standung. 81 VA. L. REV. 387, 422-28 (1995) (noting that courts generally assumed thit entorcement attuns hud to originate in courts of the govemment whose laws were being enlorecd) To the extent that Commerce Clause challenges could fit into ordinary civil actions, however, they could anse easily as betuen diverse parties. See, e.g., Henderson v. Mayor of New York. 92 U S 259 (1875) (deciding un allenuge duersuly action challenging a passenger tax). And clearly the federal couns were amenable to diversity due prucess cases. See infra notes 260-276 and accompanying text

93. Some scholars posit a spectal role for the federal courts in determining issues of federal law to the point of arguing that Congress cannot completely withdraw federal coun junsdiction over "subjet malter" as opposed to "pary-based" Anicle III categones See. e g. Akhil Reed Amar. A Neo.Federalist Vien of Article III: Separating the Two Tiers of Federal Jurisdiction, 65 B U L REV 205 (1985) (hereinutter Amar, Neo-Federalist View'] (arguing that Arucle IIl requires the vesung of tederal junsdiction. elther originally or on appeal, of federal question cases and (wo other categones of cases). Athil Recd Amar. The Two-Tiered Structure of the Judiciany Act of 1789. $138 \mathrm{U} \mathrm{P}_{\mathrm{A}} \mathrm{L}$. REV 1499 (1990) (supporting the argument through a statutory analysis); see also Lawrence Gene Sager. The Supreme Court, 1980 Term-Foreword: Constitutional Limitations on Congress Auhority to Regulate the Jurtsthction of the Federal Courts, 95 HaRv. L. REv. 17 (1981) (arguing that the history and logic of the Consutution requate that original or appellate jurisdiction vest as to constututional claums). of Rober $N$ Clinton. A Handatory View of Federal Court Jurisdiction: Early Implementation and Departures from the Consumuonal Plan. 86 CoLUM. L. REv. 1515 (1986) (arguing for mandatory aggregate vesung of all Arucle llt cases or controversies). But cf. John Harnson, The Power of Congress to Lmu the Jurusdichon of Federal Courts and the Text of Arricle III, 64 U. CHI. L. REV 203 (1997) (taking issue wih Amst's mundutory vestung arguments); Daniel J. Meltzer, The Histony and Sirucrure of Arncle III. 138 U PA L R+Y 1569) (1990) (same). In particular, Professor Amar has argued that Article III requires that federal question jurisdiction vest either originally or on appeal, but that Congress may properly choose whether to vest some. All, or none of the diversity jurisdiction. See Amar, Neo-Federalist Vien, supra, al 229-30

The use of diversity as a form of federal question junsdiction might at first glanie seem to undermine a sharp distinction between the compulsory status of federal question junsuliction on the une hand and the optional status of diversity on the other. Nevertheless, the use of diversity as a form of federal question jurisdiction may actually complement Amar's thesis—or al least not undermine il Beciause tederal question jurisdiction was probably not completely vested with the Judictary Aat of 1789, see Melt<er. supra, al 1585. the use of diversity as a form of federal question junsdicuon helped to pick up the slack in addition, to the extent this Aricle indicates that certain remedies might be constututunally compelled (whether in cases heard in state or federal courts), it might suggest required vesting of appellate jurisdiction in the Supreme Cour (or perhaps some other federal coun) over at least some state coun decisions denying consthutiona! rights. See Henry M. Hart, Jr., The Power of Congress to Lmm the Jurisdiction of the Federal Courts An Exercise in Dialectic, 66 HARV. L. REV. 1362. 1364-65 (1953) (Jrguing that exceptuns to the Supreme Court's appellate jurisdiction must not destroy uts "essential role" in the constututional plan). Leonard G Ratner, Congressional Power over the Appellate Jurisdiction of the Supreme Court. $109 \mathrm{C} \mathrm{PA}_{\mathrm{A}} \mathrm{L}$ REV 157, 161 (1960) (arguing that such essentual functions include muntaning the unitormity and supremuty of federal law). 
to manufacture diversity in both federal question and other cases. For example, corporations claiming violations of their charters were able to obtain a federal forum by having an out-of-state shareholder sue the corporation and state officials in diversity. ${ }^{94}$ Eventually, however, the Court acknowledged the flood of diversity cases that had come into federal courts as derivative actions. ${ }^{95}$ As a corrective measure, the Court announced in Hawes $v$. Oakland $^{96}$ that it was promulgating an equity rule requiring an affidavit from the plaintiff stating that "the suit is not a collusive one to confer on a court of the United States jurisdiction of a case of which it would not otherwise have cognizance." $" 97$

In thus conditioning derivative actions, however, the Court did not seem driven by a concern that federal question cases would slip into federal court under the diversity rubric. The Court noted that its earlier decision upholding diversity jurisdiction in Woolsey had been partly motivated by the suit's having involved federal issues and by the fact that the bank's citizenship of the same state as the defendant officers would have precluded a federal forum for those issues except by way of section 25 review. ${ }^{98}$ The Court reasoned that because a party in the position of the bank in Woolsey could now bring an original federal question suit under the 1875 Act to restrain the collection of the tax in its own name, there was less reason to allow for shareholder (i.e., diversity) suits in such cases. ${ }^{99}$

94. See, e.g., Humphrey v. Pegues, 83 U.S. (16 Wall.) 244 (1872) (reporting a shareholder suit by a Mississippi citizen against a South Carolina corporation and two South Carolina county officers to enjoin collection and payment of a tax alleged to violate the Contracts Clause), described in Gunter v. Atlantic Coast Line R.R., 200 U.S. 273, 278-79 (1906) (involving subsequent proceedings in the same case); Tomlinson v. Branch, 82 U.S (15 Wall.) 460 (1872) (reviewing a suit by shareholders of the South Carolina Railroad Company against the company, the state auditor, and county collectors to enjoin payment and collection of a tax alleged to be in violation of the company's charter). While these cases do not explicitly allude to collusion, it is hard to imagine that shareholders and officers did not cooperate to obtain a federal forum in many derivative cases alleging state violations of corporate charters or other unconstitutional stute action.

95. See Hawes v. Oakland, 104 U.S. 450, $452-53$ (1881).

96. See id. at 461 .

97. Additional Rule of Practice in Equity No. 94, 104 U.S. at ix-x (1882). The rule stated:

Every bill brought by one or more stockholders in a corporation, against the corporation and other parties, founded on rights which may properly be asserted by the corporation, must be verified by oath, and must contain an allegation that the plaintiff was a shareholder at the time of the transaction of which he complains, or that his share had devolved on him since by operation of law; and that the suit is not a collusive one to confer on a court of the United States jurisdiction of a case of which it would not otherwise have cognizance. It must also set forth with particularity the efforts of the plaintiff to secure such action as he desires on the part of the managing directors or trustees, and, if necessary, of the shareholders, and the causes of Id. his failure to obtain such action.

98. See Hawes, 104 U.S. at 458-59.

99. See id. at 459 . In addition, the Court may have wanted to assure for the most part managerial control of rights to sue for the corporation. See HovENKAMP, supra note 10, at 43-45 (charactcrizing the Court as moving toward seeing management and not shareholders as the appropriate parties to sue on behalf of the corporation, but trying to protect the underlying rights of the shareholders and thus allowing derivative actions to protect constitutional rights in appropriate circumstances). 
The Court, moreover, did not seem strictly to enforce the noncollusion requirement when constitutional issues were combined with irreparable harm. ${ }^{100}$ Thus, shortly after Hawes, in a shareholder action raising Contracts Clause issues and making strong allegations of irreparable harm, ${ }^{101}$ the Cour found that the suit met the noncollusion requirements set forth in its new equity rule. ${ }^{102}$ It did so even though the corporate directors' only objection to bringing suit was, as in Woolsey, "that the assertion of the rights of the corporation in the State courts is accompanied with so many embarrassments that they decline to attempt it." 103 The shareholder suit brought in diversity therefore continued to be a prominent vehicle for raising constitutional issues, notwithstanding the Court's new limits on manufacturing federal jurisdiction. ${ }^{104}$

Similar to the Court's allowance of shareholder suits to create diversity on behalf of corporations challenging allegedly unconstitutional state action was the Court's allowance of suits by out-of-state trustees of bonded indebtedness

100. The new rule, however, did result in dismissal of some denvative stctions rassing lederal questions. See, e.g., Huntington v. Palmer, 104 U.S. 482.484 (1881) (rejectung on a number ut gruunds under Hawes a derivative action that alleged that the directors were paying an unconstitutiunal tux)

101. See Greenwood v. Freight Co., 105 U.S. 13 (1881) Legislation had repested the cumpany"s chaner, and a new company had been chanered to take over its tracks on payment of compensuttun. such that the case presented "so strong a case of the total destruction of the corporate cxistence. and of the annihilation of all corporate powers under the Act of 1872, thal we think complainant as $\downarrow$ stuckholder comes within the rule laid down in [Hawes]." Id. al 16. The Supreme Cour. however. found aysust the old company on the merits on the Contracts Clause claum because of state legislation reserving nghis to amend and repeal chaners. See id. at 17.

102. See id. at 16 .

103. Id. at 15; see also Cotting v. Kansas City Stock Yards Co. 183 U S 79. 113-14 (1\%01) (rejectung a suggestion that a suit was collusive in that corporate officers agreed wath shareholders that the stalute at issue was unconstitutional); McGovney, supra note 46, at 892 (ubjectung that Greemuced allowed s derivative action based on allegations similar to those in Woolsev)

104. See, e.g., Cotting, 183 U.S. at 79 (ententanng a suit by \& Messathusetts shatchulder ayanst Kansas corporate officers contesting under the Founeenth Amendment the validily of a statute regulatung stockyards); Pollock v. Farmers' Loan and Trust Co., 157 U S 429.553 (1895) (allowing a Mass.thusets shareholder to sue a New York corporation to contest the federal income tax). see also Steven L Winter. The Metapitor of Standing and the Problem of Self.Governance. 40 STAN L RtV 1371. 14+11 (1988) (discussing shareholder suits); $c f$. Prout v. Starr, 188 U S. 537 (1903) (allowing a shareholder suit to enjoin enforcement of unconstitutional rates without clanfying the basis of junsdiction)

The derivative suit and constitutional litgation agaunst enforement officers had a certatn theorettial affinity, because the shareholder suit against the corporate officers was based on a theory thut they were acting ultra vires in complying with unconstitutional taxes or rate regulations, and the underlying corporale suit against the officer was based on a theory that the officer acted ulira vires in commitung trespassury harms under an unconstitutional statute. Cf. HoveNkAMP. supra note 10. at 59 (discussing the theory ut ultra vires acts as justifying quo warrant actions and shareholder suits) The shareholdet action may also have bolstered somewhat the claim for equity jurisdiction. because the companies un whuse behalt the shareholders sued might have had a harder time than shareholders in cluming the inadequacy of remedtes at law (quite apart from the difficulties of obtaining subject matter jurisdiction) See, $8 \mathrm{~g}$. Ashu ander Tennessee Valley Auth., 297 U.S. 288 (1936) (entertaning a challenge by shareholders of a pnville power company that had contracted with the Authonty to the legality of the Authorily's building of $\&$ dan to which the contract related); Smith v. Kansas City Title \& Trust Co. 255 U S 180 (1920) (entertunung \& shareholders' suit to enjoin a bank's investment in bonds issued under 1 federal law that was alleged to exceed congressional power); Ex parte Young. 209 U.S 123. 129 (1908) (describing the proxecdings that resulted in a contempt order against the state attorney general as nine equity suits tiled by stotkholders ot particular railroads). 
of state-chartered railroads. Federally chartered railroads did not need this device, for they had access to federal court after the passage of the 1875 general federal question and removal statutes, based on the theory of Osborn v. Bank of the United States ${ }^{105}$ that their charter created a federal question. ${ }^{106}$ If not federally chartered, however, a railroad would ordinarily be chartered in all states through which it ran. ${ }^{107}$ Therefore, it might have had difficulty obtaining diversity jurisdiction in a suit against state and local officials of any state in which it was chartered and of which, arguably, it was a citizen. ${ }^{108}$

Most railroads, however, were financed by bonded indebtedness, ${ }^{109}$ and federal courts treated bond trustees-those who represented the interests of the bondholders and were authorized to act on their behalf-as proper complaining parties where state rate regulation seriously threatened railroad revenues. ${ }^{110}$ So long as the trustee was a citizen of a state other than that of the state official being sued, federal courts would typically uphold their jurisdiction

105. 22 U.S. (9 Wheat.) 738 (1824).

106. It did not matter for federal jurisdiction whether the claim by or against the federally chartered railroad actually implicated a construction of federal law. See Pacific R.R. Removal Cases, 115 U.S. 1 (1885) (stating that suits by or against federally chartered corporations were suits arising under the laws of the United States). Removal based on federal defenses was allowed between 1875 and 1894 . See Collins, supra note 25, at 719-37. A 1915 statute terminated the ability of railroads to base jurisdiction on federal incorporation. See Act of Jan. 28, 1915, ch. 22, § 5, 38 Stat. 803, 804.

107. See, e.g., Railroad Comm'n Cases, 116 U.S. 307, 316 (1886) (noting that a railroad was chartered in Mississippi and three other states).

108. A number of Supreme Court decisions, however, mitigated the effects of multiple citizenship by treating the corporation as a citizen of only one state for some purposes. Indeed, it was only in 1958, when Congress provided that a corporation would be a citizen of any state of incorporation and its principal place of business, that the preexisting doctrine was eliminated. See Act of Sept. 2, 1958, Pub. L. No. 85-920, 72 Stat. 1770, 1770; cf. Moore \& Weckstein, supra note 33, at 11-12 (stating that the 1958 revisions "may" have eliminated this doctrine). The Court had previously treated multi-state-chartered corporations us citizens only of the states in which they were sued (if they were chartered there), by reasoning that a corporation chartered within a state was operating within that state only by virtue of the laws of that state. See Henderson, supra note 46, at 71-72 (discussing Muller v. Dows, 94 U.S. 444 (1876); Railway Co. v. Whitton, 80 U.S. (13 Wall.) 270 (1871)). Before Whitton, the Court had reached a contrary result. See Bank of Augusta v. Earle, 38 U.S. (13 Pet.) 519 (1839). In an 1890 case, the Court held that when the corporation was a plaintiff in a diversity action, it could choose the state of which it wanted to be a citizen. See Nashua \& L.R.R. v. Boston \& L.R.R., 136 U.S. 356 (1890). Subsequent doctrine developed that a corporation forced to incorporate in other states would be deemed a citizen only of its original state of incorporation. See HENDERSON, supra note 46, at 95. Corporations simultaneously incorporated in several states, however, could not disregard citizenship of such states. See Patch v. Wabash R.R., 207 U.S. 277, 283 (1907). The doctrine in the area remained somewhat unclear. See HENRY M. HART, JR. \& HERBERT WECHSLER, THE FEDERAL COURTS AND THE FEDERAL SYSTEM 909-12 (1st cd. 1953) (discussing uncertainties in the area of multiple incorporation); Frankfurter, supra note 3, at 523 (noting confusions in the law of corporate citizenship).

109. See State R.R. Tax Cases, 92 U.S. 575, 604 (1875) (noting that it may be assumed that cvery railroad had bonded indebtedness secured by one or more mortgages). These cases also set conditions on suits to enjoin taxes. See id.

110. See, e.g., Reagan v. Farmers' Loan \& Trust Co., 154 U.S. 362 (1894) (involving a trustec on a trust deed who brought suit to enjoin rates as unreasonable); $c f$. Rolston v. Missouri Fund Comm'rs, 120 U.S. 390 (1887) (deciding an equity suit brought by mortgage trustees against state officials to enjoin the sale of a railroad under a statutory lien to the state, where the trustees claimed that by terms of another statute the lien had been satisfied). 
despite the lack of diversity between the railroad and the defendant public officials. ${ }^{111}$

\section{Sources of Remedial Rights in Diversity Actions: The Interstitial Nature of State Law}

This Article has shown thus far that the Supreme Cour expansively interpreted diversity jurisdiction with the express purpose of providing a federal forum for federal constitutional questions. This section explores whether these diversity actions implicating constitutional issues fairly can be characterized as state law causes of action with interstitial federal elements, or whether such actions took on a more distinctly federal cast.

In the nineteenth century, judicial enforcement of the Constitution largely occurred through the nullification of statutes. In state court actions brought by state officials to enforce state laws, such nullification might be occasioned by the defendant's defense that the statute under which he was prosecuted was unconstitutional. ${ }^{112}$ In civil actions that were maintained in federal court under diversity jurisdiction, the invocation of the Constitution by the courts occurred in a variety of ordinary claims for relief." Among the most common of these was the trespass action against state or local officials for harms to property and comparable suits for injunctions to protect against imminent trespass. The issue of the constitutionality of the statute on which the state official had relied would be raised by the plaintiff to negate the claim of justification. Ordinary contract actions and other types of suits could also provide vehicles for raising federal questions in private law disputes.

111. Receivership was also a route to federal coun. See, e $g$. Davis * Gray, 83 U S (16 Wall ) 203. 216 (1872) (affirming relief in a suit by the New York receiver of a rallowd agannst the Texas governor and the commissioner of the land office on behalf of a ralroad incorporated under Texas law to stop those officials from issuing land patents in violation of the Contracts Clause nghts of the raulrosd). see also HOVENKAMP, supra note 10 , at 148 (staung that by 1895, one-fourth of Amencan rallusds were in receivership); Garrard Glenn, The Basts of the Federal Recenership. 25 CoLUM L REV +34. 434 (1925) (noting that federal cours were undoubtedly the chosen forum for reorganization by receivership) The receivership actions generally did not rely on federal bankruptcy laws. which were in force unly from is00 to 1803 , from 1841 to 1843 , from 1867 to 1878 , and contunually from 1898 See HakT \& WECHSLER, supra note 108, at 580; see also HENRY L. MCCLINTOCK. HANDBOOK of EQUITY 361 (1936) (noung that the 1898 statute was inapplicable to ralroads). While recevership stions in federal coun might be iniluated by a diverse creditor, after 1884 the practice developed that the rulrouds could inutuate the actions aganst creditors. See Wabash, St. L. \& Pac. Ry. v. Central Trust Co., 22 F 273 (D Mlo i884), discussed un D H Chamberlain, New-Fashioned Receivershps, 10 HaRV. L REV 139, 142. 146, 148 (1896) (cruciang the widespread use of receiverships at the instance of ralroads in the absence of bankrupicy laws) Ancillary actions to the receivership might be filed in other federal couns See, e g. Davis, 83 U S at 216 (indicating that the case was auxiliary to the onginal suit by the mortgage irustee to put the company into receivership).

112. As noted above, both criminal and civil enforcement actuons were generally confined to the cuurts of the sovereign whose laws were being enforced. See Woulhandler \& Collins, supra nule 92. 4l \$22-28

113. See Alfred Hill, Constitutional Remedies, 69 COLUM L REV 1109.1132 (1\%69) (statung that the Constitution was to be implemented in accordance with the remedial institutions of the common law). Gene R. Nichol, Bivens, Chilicky, and Constitutional Danages Clams. 75 VA L REV 1117.1136. 1154 (1989) (same). 
One might assume that this indirect implementation of federal constitutional law through common law actions brought in diversity manifested a more respectful form of judicial federalism than later practices of bringing implied constitutional causes of action under federal question jurisdiction (as in Ex parte Young ${ }^{114}$ ) or invoking $\S 1983$ as an all-purpose constitutional cause of action (as in Monroe $v$. Pape ${ }^{115}$ ). Indeed, the traditional understanding is that, in these early common law actions, federal issues merely were being interjected into state law causes of action against the official. ${ }^{116}$ According to the influential work of Professor Hart, federal equity actions

114. 209 U.S. 123 (1908); see also PETER W. Low \& JOHN CALVIN JEFFrIEs, JR., Federal Courts AND THE LAW OF FEDERAL-STATE RELATIONS 424 (3d ed. 1994) (stating that the federal cause of action for injunctive relief stemmed from Young); cf. HART \& WECHSLER, supra note 1, at 1065 ("[I]sn't it clear that in Young, the Cour recognized a judicially implied federal cause of action for injunctive relief under the Fourteenth Amendment?").

115. 365 U.S. 167 (1961).

116. See Har, supra note 17, at 524 (arguing that federal question cases derived from state law trespass actions with federal elements); see also Wheeldin v. Wheeler, 373 U.S. 647, 652 (1963) (stating, in a case decided before the Supreme Court approved an implied constitutional damages action in Bivens v. Six Unknown Named Agents of the Federal Bureau of Narcotics, 403 U.S. 388 (1971), that "[w]hen it comes to suits for damages for abuse of power, federal officials are usually governed by local law"); Hill, supra note 113, at 1129-31 (indicating that in damages actions for unconstitutional action a plaintiff would "apparently be pressing a state-created claim"). But $c f$. id. at $1129-30$ (indicating that the sovereign source of actions in equity was uncertain). Hart saw federal question injunction actions as deriving from state causes of action in the following way:

The analysis, it may be inferred, ran something like this: (1) the general grant of federal equity jurisdiction authorizes a federal equitable remedy for breach of a duty created by state as well as by federal law, where the legal remedy is inadequate; (2) a trespass is a breach of duty under state law; (3) under state law, a showing that the defendant acted in an official capacity pursuant to a state statute is a defense to an action of trespass; and (4) as a matter of federal law, such a defense is not available if the statute under which the defendant justified his conduct violates federal law. The Court, however, came to neglect the second and crucial link in this chain of reasoning and ceased to inquire whether the acts complained of did, indeed, constitute a breach of duty under state law. By almost imperceptible steps it appears to have come to treat the remedy of injunction as conferred directly by federal law for any abuse of state authority which in the view of federal law ought to be remediable. A host of restrictions developed partly by act of Congress and partly by federal judicial decision have emphasized the federal character of this remedy.

Hart, supra note 17, at 524 (footnotes omitted). Hart apparently saw the damages remedy as still a creature of state law at the time he wrote in 1954. See id. at 528. Hart, however, was clearly aware of the federal court's use of general common law, and his characterization of background law as state law was thus partly normative. See id. at 505 (characterizing general common law in the 19th-century view as "still state law," but also as a kind of "spurious federal law"). Hart considered differences in remedy and procedure as between state and federal courts to be "inescapable if the different governments are to retain a measure of independence in deciding how justice should be administered," see id. at 508, but thought that statc and federal courts should accept the same premises of underlying primary obligation, see id. at 513 . Professor Hill's position also reflected great subtlety as to sources of law. See Hill, supra note 113, at 1129-30. While seeing actions at law raising challenges to unconstitutional official action as deriving from state law, he noted "that . . pleading conventions [in equity] had a foundation in English history wholly unrelated to any attempt to identify the sovereign source of an asserted right in a federal system." $1 d$. at 1130 . Although Hill saw more state law content in actions at law in federal court raising constitutional issues than does this Article, overall this Article's views are in agreement with Hill's ideas that the sources of remedial rights in constitutional cases in federal courts should not be seen as primarily state law. This Article also follows Hill in seeing some constitutional compulsion behind state law tort remedies for federal constitutional violations. See id. at 1144-45. His argument was addressed to supporting the propricty of recognizing a cause of action in damages under the Constitution, a position with which this Article also agrees. 
raising constitutional challenges were originally state law actions that by "imperceptible steps" came to be seen as federal causes of action." The supposition that state law provided the underlying cause of action and the remedial framework for raising constitutional issues in the pre-modem era also supports traditional theories of judicial federalism that have "viewed federal law as looming in the background, seldom displacing state law, but available to remedy its deficiencies on an "interstitial' basis." 118

The sources of law applied in these early federal question cases, however, present a more complex picture than such an approach would suggest. To sort out these complexities, it is useful to compare the "remedial rights"119 that existed in state and federal courts when they considered similar claims. In what follows, this Article will first compare procedures applied in state and federal courts, including the procedures for the enforcement of judgments. Then it will compare the basic elements of causes of action in state cours and federal diversity courts. ${ }^{120}$ These comparisons will shed light on the extent to which the federal courts did or did not follow state law in diversity cases raising federal constitutional issues. Understanding the sources of law for these federal question diversity cases will also help to locate the origins of implied constitutional rights of action against state officials eventually brought under the 1875 federal question statute.

117. Hart, supra note 17 , at 524 .

118. Fallon, supra note 17, at 353-54 (characteriang the views of Professors Han and Hill)

119. In this discussion, I use the term "remedial nghts"-a term adopted from the work of Prolessors Hart and Sacks. See HenRY M. HART, JR. \& ALBERT M. SACKS. THE LEGAL PROCESS (William $N$ Eskridge, Jr. \& Philip P. Frıckey eds , 1994). Han and Sicks distınguish promary from remedial dutues and rights. See id. at 136-37; see also H.L.A. HART. THE CONCEPT OF LAW 79-80. $89-96$ (1961) (disunguishing primary rules, which impose obligations on ordinary ciuzens in the conduct of their alfurs, and seciondury rules, which confer legislative and adjudicauve authonly on public officials) According to Hart and Sacks. people have "positions" under the authoritative directuve arrangements that govern behsvior See Hakt \& SACKS, supra, at 134-35. The basic position is that of having a "duty" to do or not to do sometheng under an authoritative directive, see id. at 130, and a nght is "a posituon which a person has beciuse sumeone else has a duty in the performance of which the nght-holder is in some way interested "/d at 134 The authoritative directive provisions create such primary nghts and dutues But the authoniatuve durectuves also must make provision for what happens if there is noncomplance These are remedial provistons. often addressed to courts. See id. at 122-23. Breach of a primary private duty may give rise "to one or more remedial rights of action," and these remedial nghts may closely reflect pnmary nghts $l d$ at 137 But the breach of a primary private duty does not necessarily give rise in every case to a remedial prvate duty. nor does the existence of a primary nght necessanly gwe a remedtal nght to the person who is in the position of primary right-holder. For example, the government may be the only pany slluwed to bring actions for breaches of primary duties, even though pnwate partues may be promary nghi-holders See ad at 137. Similarly, a third-party beneficlary may be seen as having a prumary nght without a remedial nght See id. at 136. See generally Richard H. Fallon, Jr. \& Daniel J Meltzer, New Law. Non-Retroactun, and Constitutional Remedies, 104 HARV. L. REV. 1731. 1758-77 (1991) (arguing that nonretroactuvily decistons are best understood as part of the law of remedies, rather than in terms of the debale as to whether law is "made" or "found").

120. This Article does not purpont to supply a complete companson of actions in federat and state coun. Rather, the research reflected herein focuses on cases rasing poiential federal questions where $a$ litigant raised an issue of nonconformity to state law substance or practuce 


\section{Procedures and Remedies}

Federal courts exercising equity jurisdiction followed their own procedures rather than state procedures, even in diversity cases. For actions at law, however, various congressional statutes directed the federal courts to use state procedures; ${ }^{121}$ indeed, it was not until 1938 that the federal courts adopted a full set of their own rules of procedure for both law and equity. ${ }^{122}$ Before the Conformity Act of $1872,{ }^{123}$ the Supreme Court interpreted the various "process acts" in which Congress had directed the federal courts in actions at law to use state procedures as prescribing "static" conformity. ${ }^{124}$ That is, the procedures of the state in which the federal court sat were to be adopted as they existed at the time Congress enacted the applicable process act. ${ }^{125}$ In 1872 , Congress switched to "dynamic" conformity, directing federal courts in actions at law to keep up with changes in state procedures that occurred subsequent to the federal statute's enactment. ${ }^{126}$

Despite these apparent congressional directions to adopt state procedures in actions at law, the Supreme Court nevertheless saw federal procedures as decidedly within the control of the federal courts. The Court indicated that state procedures were not applicable in federal courts of their own force, nor (it further suggested) could they be, insofar as federal courts were

\section{The First Process Act, ch. 21, 1 Stat. 93 (1789), provided:}

[U]ntil further provision shall be made, and except where by this act or other statutes of the United States is otherwise provided, the forms of writs and executions, except their style, and modes of process and rates of fees, except fees to judges, in the circuit and district courts, in suits at common law, shall be the same in each state respectively as are now used or allowed in the supreme courts of the same.

$\$ 2,1$ Stat. at 93 . The Permanent Process Act of 1792, ch. 36, §2, 1 Stat. 275, 276, was worded similarly, but also made such adherence to state procedures subject to the rulemaking power of the Supreme Count and lower federal courts, as did subsequent acts adopted to accommodate later-admilted states, see, e.g., Act of Aug. 1, 1842, ch. 109, 5 Stat. 499; HART \& WECHSLER, supra note 1, at 661-63. "Modes of process" was construed liberally as covering all steps in a proceeding. See 2 JAMES WM. MOORB ET AL., MOORE's FEDERAL PRACTICE II 2.03, at 2-9 n.15 (2d ed. 1988) (citing Wayman v. Southard, 23 U.S. (10 Wheat.) 1, 27-28 (1825)).

122. See HART \& WECHSLER, supra note 1, at 664-65.

123. Ch. 255,17 Stat. 196. The Conformity Act provided "[t]hat the practice, pleadings, and forms and modes of proceeding in other than equity and admiralty causes in the circuit and district courts of the United States shall conform, as near as may be, to the practice, pleadings, and forms and modes of proceeding existing at the time in like causes in the courts of record of the State within which such circuit or district courts are held, any rule of court to the contrary notwithstanding . . ." \$ 5, 17 Stat. at 197. The provision was incorporated into the revised statutes, and remained until the Federal Rules superseded it. See MOORE ET AL., supra note 121, II 2.04[1], at 2-13. Contemporaneously with the Conformity Act, Congress provided that procedures for execution of judgments would continue under static, but updated conformity, subject to further updating by rules of court. See id. $\$$ t 2.03 , at 2-11.

124. See Wayman, 23 U.S. (10 Wheat.) at 32. The Process Act of 1828, ch. 68, 4 Stat. 278, 278-79, updated procedures for execution of judgments to the procedures in effect in state courts in 1828. See HART \& WECHSLER, supra note 1, at 662; MOORE ET AL., supra note 121, II 2.03, at 2-10 to 2-11.

125. See MOORE ET AL., supra note $121, \mathbb{I} 2.03$, at 2-12. Later-admitted states, therefore, might be under different process acts from the original states. See HART \& WECHSLER, supra note 1, at 662.

126. See supra note 123 . 
instrumentalities of a different government. ${ }^{127}$ Rather, state rules were in force only because they had been adopted by Congress for federal courts, and their source was therefore federal. ${ }^{128}$ Accordingly, the Supreme Court acted as though state procedures, although applicable in federal courts, should not unduly constrain them, particularly in the enforcement of federal rights. ${ }^{129}$

\section{a. State Limits on Enforcement in Actions at Law}

In Wayman $v$. Southard, ${ }^{130}$ a diversity case, Kentucky law allowed judgment debtors to post bonds that delayed executions of judgments for two years. The Supreme Court could have declared that the law allowing for the two-year delay was an unconstitutional impairment of contracts that had been entered into before the enactment of the law. ${ }^{131}$ But in Wayman, the Court reached the same result simply by holding the Kentucky execution law inoperative in federal court. ${ }^{132}$ It was in Wayman that the Court interpreted the process acts to provide only for static conformity to state procedures, such that only those procedures in effect in 1789 (the date of the original process act) would apply in the Kentucky federal court. ${ }^{133}$ Because Kentucky's statute delaying execution of judgments was enacted after 1789, the federal courts did not have to adhere to the later-enacted state procedural provisions.

Contemporaneously with Wayman, the Cour held inapplicable to the enforcement of a federal judgment still another Kentucky statute providing that

127. See United States Bank v. Halstead, 23 U.S. (10 Wheat) 51.63 (1825) (statung that an officer of the United States cannot be controlled in the discharge of his dutues by state laws any further than such laws have been adopted by Congress, and in such case the officer acts under federal not state authonty). Wayman, 23 U.S. (10 Wheat.) at 49-50 (1825); see also Riggs v Johnson County. 73 U S (6 Wall) 166. 195 (1867) (stating that the efficacy of state procedures in federal courts depends on an ater of Congress). Hart, supra note 17, at 529 (maintaining that state law is nol operaltve of its own forte when adopted for federal procedures).

128. See Wayman, 23 U.S. (10 Wheal.) al 35, 49

129. Cf. MOORE ET AL., supra note 121, \& 2.0411], at 2-15 (stating that the Conformity Act was interpreted elastically, for example, permitung "a federal coun to disregard a state pratetuce that tended to defeat a federal substantive right"); Fletcher, supra note 42. at 1532-33 (notung thal foderal courts did not generally follow state law as to process and remedies); supra note 121. mfra note 174

130. 23 U.S. (10 Wheat.) 1 (1825)

131. Cf. Bronson v. Kinzie, 42 U.S. (1 How.) 311 (1843) (holding volatuve of the Contracts Clause. as applied to a previously entered mongage. state statutes that provided for a 12-month redemption penod and stipulated that judicial sale had to be for at least (wo-therds of the apprased value). Warren. supra nute 81, at 24-25 (noting that the Cour avoided the constutuuonal issue in Wayman by deciding that the state statute would not apply in federal courts); see also FREYER, supra note 25. al 27-28 (discussing Waymen's rejection of the argument that state law should control under secuon 34 of the Judictary Act of 1789). DWIGHT WILEY JESSUP, REACTION AND ACCOMMOdATION: THE UNTEU STATES SUPREMIE COUKT AND POLITICAL CONFLICT 1809-1834, at 229 (1987) (discussing the political reaction to the Supreme Cour's decisions as to execution of judgments).

132. See Wayman, 23 U.S. (10 Wheat.) al $41-42$ Because Contracts Clause doctnnes would require substantially equivalent remedies to those in effect at the ume of the contract, the use of older procedures could have the same effect as a declaration of the unconstututionality of the newer procedures

133. See id. at 32. The 1792 Process Act made permanent the $1789 \mathrm{Act} 1789$ remaned the applicable year for state procedures that were onginally adopted under the 1789 Act and contunued under the 1792 Act. See supra note 121. 
land could not be sold in execution of a judgment unless the sale price equaled at least three-fourths of appraised value ${ }^{134}$-a statute that likely violated the Contracts Clause as applied to obligations incurred before its enactment. ${ }^{135}$ Rather than reach the constitutional issue, however, the Court again held that the execution statute did not apply in federal court because the statute had not been part of the state's procedure in $1789 .{ }^{136}$

Interestingly, at the same time that the Court refused to apply a state's post-1789 procedural restrictions on land executions, it held that federal courts could execute on land even though the state had not allowed for such executions until after $1789 .{ }^{137}$ The process acts, while adopting 1789 state procedures, were read as giving the federal courts discretion to adopt newer state procedures if they wished. In short, static conformity did not restrict federal courts if they found newer state procedures more conducive to the enforcement of federal rights and federal judgments. ${ }^{138}$ Indeed, Chief Justice Marshall indicated in Wayman that the process acts had been designed specifically to allow federal courts to avoid using state debtor relief legislation. ${ }^{139} \mathrm{He}$ observed that in some states,

the pressure of the moment had produced deviations from that course of administering justice between debtor and creditor, which consisted, not only with the spirit of the constitution, and, consequently, with the views of the government, but also with what might safely be considered as the permanent policy, as well as interest, of the States themselves. ${ }^{140}$

Congress, he concluded, intended the federal courts to have the flexibility to follow state law when the states returned to wiser policies. ${ }^{141}$ Thus, the Supreme Court interpreted the process acts to provide for federal court flexibility to adopt or ignore state procedures and thereby to ignore state debtor relief legislation that likely violated the Contracts Clause.

\section{b. State Restrictions on Equity}

In equity, where Congress had not directed the use of state procedures, the federal courts provided effective relief for federal rights claimants with even

134. See United States Bank v. Halstead, 23 U.S. (10 Wheat.) 51 (1825).

135. See supra note 131 .

136. See Halstead, 23 U.S. (10 Wheat.) at $52,54,65$.

137. See id. at 59-60.

138. See id:; see also Wayman, 23 U.S. (10 Wheat.) at 41-42 (stating that while Congress adopted laws as they were in force in 1789 , it also provided for making improvements and adopting state laws that might vary from provisions in force in 1789).

139. See Wayman, 23 U.S. (10 Wheat.) at 46-47.

140. Id. at 46-47.

141. See id. at 47. 
less attention to the strictures of state law than in actions at law. ${ }^{1.2}$ The Judiciary Act of 1789 contemplated that federal equity courts might grant remedies in diversity cases even when no equitable remedies existed under state law. ${ }^{143}$ State law might, for example, limit remedies for illegal tax collection to a trespass suit against the collector, while injunctive relief might be unavailable under state law or even expressly forbidden. Such restrictions on remedial rights in state court, however, did not affect federal jurisdiction to enjoin an illegal state tax in appropriate cases even when the only basis for jurisdiction was diversity. Indeed, restrictions on the actions available in state court could actually bolster an argument that the remedy at law was inadequate-a basic requirement for federal equity jurisdiction under the 1789 Act. ${ }^{144}$ For example, if state practice required separate suits at law against several county collectors by a taxpayer who was subject to taxes in several counties, the multiplicity of suits at law could make such remedies inadequate and thus open the door to federal injunctive relief in diversity. ${ }^{\text {is }}$

\section{c. Forum Restrictions}

In suits in both law and equity, states were generally unsuccessful in arguing that actions created by state legislation could, by that same legislation, be limited to certain state forums so as to preclude federal jurisdiction. For example, in a bondholder's federal court diversity action to recover on county bonds, the defendant county argued that there was no federal jurisdiction in

142. Cf. Cates v. Allen, 149 U.S. 451,456 (1893) (holdang that a contract credilor who had not reduced his claim to judgment had no standing in federal equity cour to set aside a fraudulent conveyance, even if the state court would allow the surt): Scolt v. Neely. 140 U S 106. 109.10 (1891) (Implying that the fact that state courts would give equitable relief did not mean that (ederal courts would give it); HoRwIT, supra note 10, at 250 (noting that prior to Sw'ft s: Tyson, 41 U S (16 Pet) 1 (18+2), the Court had avoided close inquiry into the specific sources of legal nght by framing the recognutuon of negouabilty in terms of equitable remedies).

143. See Robinson v. Campbell, 16 U.S. (3 Wheat.) 212, $221-23$ (1818) (ressoning from the fact that some states provided no equitable remedies to a conclusion that federal courts could grant remedies in law and equity different from those state courts would provide); Hill, supra note 113, at 1142; see also FrEYER. supra note 25 , at 28 (discussing Robinson).

144. Section 16 of the Judiciary Act of 1789 provided "[i]hat sutts in equity shall not be sustaned in either of the courts of the United States, in any case where plann. adequate and complete remedy may be had at law." Ch. $20, \S 16,1$ Stat. 73, 82. For discussion of the later doctrine that the adequate remedy at law had to be available in federal courts, see infro note 340 .

145. Cf. Tomlinson v. Branch, 82 U.S. (15 Wall.) 460,460 (1873) (reciung in the statement of farts that shareholders, in a successful suit to enjoin payment and collection of a tax violating the Contracts Clause, alleged that "no adequate legal remedy existed under the laws of the State to obtain redress") State remedies' becoming more adequate, however, did not necessanly Immi federal equity, where the propnety of maintaining an equity action was a maluer of federal law basod on histoncal chancery practices See. $\mathrm{g}$. Mississippi Mills v. Cohn, 150 U.S. 202, 204-06 (1893) (Indicating that a state's providing a remedy at law as to fraudulent conveyances did not affect whether federal equity was avalable. which depended on whether equitable relief was available when the Constutution was adopled). Benjamin F Keller, Jurtsdiction of the Federal Equity Courts As Affected by State Stasuses, 47 Ast L REV 190, 191. 204 (1913) (discussing McConihay v. Wright, 121 U.S. 201. 206 (1887), a case in which the statc practuce allowing a pary in possession of land to maintain an ejectment actuon dud not prevent the plainuff from mantauning a federal equity action to quict title); see also infra note 153 
light of a state supreme court decision that counties could not be sued at common law independent of legislative provisions, which only allowed suit in the state circuit court of the county. ${ }^{146}$ The U.S. Supreme Court found such reasoning inapplicable to the federal courts, on the ground that state legislation could not limit the "constitutional right" of the diversity plaintiff to sue in federal court. ${ }^{147}$ Subsequently, in a challenge to railroad rates as confiscatory in Reagan v. Farmers' Loan \& Trust Co., ${ }^{148}$ the Court rejected a similar argument that state legislation limiting judicial review of commission-set rates to the courts of a particular county ${ }^{149}$ should be read as precluding federal jurisdiction to review the commission's actions. ${ }^{150} \mathrm{~A}$ federal court was therefore able to hear the challenge, state court limitations notwithstanding.

\section{Elements of Claims}

Some of the preceding examples show that remedies could be more effective in federal court than in state court in both law and equity, particularly in cases raising constitutional issues under the diversity rubric. Nevertheless, it might be argued that the federal courts merely provided more effective remedies for underlying causes of action that were otherwise similar to those that could be brought in state courts. ${ }^{151}$ For example, it might be argued that a federal equity diversity suit merely reincarnated the state law trespass action and protected the same common law interests in property from unauthorized invasions-albeit more effectively - by obviating interim losses and a multiplicity of lawsuits.

146. See Cowles v. Mercer County, 74 U.S. (7 Wall.) 118, 118-21 (1869).

147. See id; see also Chicot County v. Sherwood, 148 U.S. 529, 534 (1893) (relieving county bondholders suing in diversity from compliance with a later-enacted state law requiring presentation of the demand to county court); Lincoln County v. Luning, 133 U.S. 529, 531 (1890) (rejecting the argument that the federal court was without jurisdiction because the statute under which bonds were issued provided for litigation concerning the bonds and named a court in which such litigation could be had). In Shenvood, the Court rejected an argument that the county could be sued only in a manner provided by state statute and that otherwise no case or controversy could arise. See Shenwood, 148 U.S. at 533-34. It also noted that its decision not to require compliance with the later-enacted state statute avoided a Contracts Clause problem. See id. at 534.

148. 154 U.S. 362 (1894).

149. See id. at 392 (noting that state legislation provided that a party dissatisfied with a rate could filc a petition "in a court of competent jurisdiction in Travis County, Texas, against said commission as defendant'" (contrasting the state provision with Act of June 3, 1884, ch. 64, $\$ 2,23$ Stat. 35, 35, which established a federal court system in Texas)).

150. See id. at 391 (stating that a state could not limit redress to suits in its own courts); id. at $391-92$ (interpreting a state statute providing for suit against the commission in any court of competent jurisdiction in Travis County as allowing suit in the federal court in Travis County); see also Smyth v. Ames, 169 U.S. 466, 516-17 (1898) (entertaining a federal equity action brought by a diverse shareholder despite a state statute providing that challenges to rates were to be brought in the state supreme court and in the name of the railroad company).

151. Cf. Hart, supra note 17 , at 508 (expressing the belief that some differences in remedy and procedure between state courts and federal courts in enforcement of federal rights "are inescapable if the different governments are to retain a measure of independence in deciding how justice should be administered"). 
At a high level of generality, federal court actions in law and equity protected similar primary rights as did state courts-that is, rights to the protection of property and contractual rights. And, of course, both state and federal courts were required to follow the Constitution in claims brought before them. At lower levels of generality, however, important differences appear. The use of the general common law in federal courts obviously meant that there might be some significant differences in rules of decision and hence ultimate results-e.g., a negotiable instrument or a municipal bond might be enforceable in federal but not state court as a matter of substantive law. One might, however, think such differences would be less salient in diversity cases raising federal questions where state and federal courts were bound by the same substantive rules of decision as to federal issues. Nevertheless, in diversity cases raising federal questions, differences between federal and state courts could extend to basic elements of claims, such as who could bring them, against whom they could be brought, and what the type of action was-that is, to the very essence of the claim for relief.

\section{a. Parties}

To some extent, differences between state and federal courts as to who could bring suits may be implicit in the notion that federal equity would grant remedies regardless of whether states had equity courts. A claimant in equity might be enforcing interests that would not be recognized in actions at law. ${ }^{152}$ Federal courts, moreover, followed federal notions of who was a proper claimant in equity. ${ }^{153}$ Particularly, the desire to enforce federal rights in diversity suits could lead to recognition of a right of action (or in modern terminology, "standing") in federal court for persons who likely would have been unable to sue in state court under comparable circumstances. For example, in Dodge v. Woolsey, ${ }^{154}$ the Court allowed out-of-state shareholders

152. See Chapman v. County of Douglas, 107 U.S 348 (1882) (holuting that rescission was avalable to allow recovery of land although on similar facts the state coun had sustaned a demurner to the damages action on the ground that counties could not enter such mongage agreements). 2 WILLAM WLNSLOW CROSSKEY, POLTICS AND THE CONSTITUTION IN THE HISTORY OF THE UNTTED STATES 880 (1953) (stating that federal couns in equity recognized substantive nghts different from those that the state courts recognized); see also FREYER, supra note 25, at 44 (stating that foderal judges ignored stale law in cases in equity); cf. Guffey v. Smith, 237 U.S. 101, 114 (1915) (holding that the lllinous Supreme Courn's limitation of the plaintiff to a particular legal remody did not preclude a foderal coun frum granung additional equitable remedies). But cf. HART \& WECHSLER, supra note l. at 710 (noung the likelihood that federal courts sitting in states lacking equity courts clatmed power to create substantive nghts denied by state law, but concluding that the cases were inconclusive); Alfred Hill. The Ene Doctrine in Bankruptcy. 66 HARV. L. REV. 1013, 1028-29 (1953) (stating that although the Coun had indieated in dicta that federal equity might grant a remedy even where the state did not recognize the underlying nght, the broad implications of this dicta were never realized to any significant degree)

153. The federal courts frequently stated, however, that if state law created new substantuve rights that could be enforced in conformity with federal equity. such enforement could be had in a federal coun 1 a ground for jurisdiction existed. See, e.g., Henrietta Mills v Rutherford County. 281 U S 121.127 (1930)

154. 59 U.S. (18 How.) 331 (1855); see also supra notes 64-78 and accompanying texi 
in a derivative action to question the corporation's liability for a tax alleged to violate the Contracts Clause. The state likely would not have recognized a right to sue on the part of the shareholders in such circumstances in state court. ${ }^{155}$ Much later, in Smyth v. Ames, ${ }^{156}$ the Court allowed a suit brought by diverse shareholders against a Nebraska corporation and state officials to enjoin the implementation of a railroad rate schedule, despite a state law expressly providing that challenges to rates could be brought only in the name of the railroad and against the state as defendant. ${ }^{157} \mathrm{~A}$ federal court could not have entertained the action in the form prescribed by the state statute. The requirement that the railroad be named as the plaintiff would have precluded diversity, while the requirement that the state be named as the defendant would have created a sovereign immunity bar. By allowing the shareholders to sue individual state officers, the Court allowed both the plaintiffs and defendants to vary from who they would have been under state law, thus accommodating federal jurisdiction over matters raising questions of federal law. ${ }^{158}$

\section{b. Elements and Forms of Action}

Just as in equity, the federal courts in actions at law did not let restrictions on actions available under state law limit the exercise of their own jurisdiction. As previously noted, the Court in Deshler v. Dodge $e^{159}$ allowed a statechartered bank to contest in federal court a tax it alleged had violated its charter rights, by the assignment of bank notes that had been seized to an outof-state party. ${ }^{160}$ The action, however, not only stretched diversity jurisdiction by rejecting an Assignee Clause challenge to jurisdiction, but also stretched the substantive requirements for a replevin action under state law. A state statute required that no writ of replevin should issue without an affidavit that the property in question was the plaintiff's and that it had not been taken "'for the payment of any tax, fine, or amercement assessed against the plaintiff."'161 Although the plaintiff had given such an affidavit in Deshler, it was only true in the technical sense that the assignee who was suing (as opposed to the bank that assigned ownership of the notes to him) had never owed any taxes. ${ }^{162}$

155. See Woolsey, 59 U.S. (18 How.) at 332-33 (argument of counsel).

156. 169 U.S. 466 (1898).

157. See id. at 474 (statement of the case); id. at 516-17 (rejecting the argument that the availability of a state court action precluded federal equity jurisdiction). While there was apparently diversity in $S m y t h$, the Court indicated federal question jurisdiction would also be appropriate. See id. at 518; see also Reagan v. Farmers' Loan \& Trust Co., 154 U.S. 362, 391-93 (1894) (entertaining diversity jurisdiction where state legislation provided for suits in a particular county's courts against the commission as defendant).

158. Similarly, it is unlikely the states would have recognized the right of action in bond trustecs whom federal diversity courts permitted to challenge taxes and rate regulations on the part of the rallroads.

159. 57 U.S. (16 How.) 622 (1853), discussed supra notes $69-72$ and accompanying text.

160. See id. at 631 .

161. Id. at 633 (Catron, J., dissenting) (quoting the Ohio statute without citation).

162. See id. at 623 (setting forth the affidavit of plaintiff Deshler, who swore "that the said goods and chattels were not taken in execution on any judgment against the said John G. Deshler, nor for the payment 
Despite protestations of the dissent in Deshler, ${ }^{163}$ the majority opinion made no mention of the state statutory requirement. ${ }^{164}$

The Court similarly ignored the form of state causes of action in municipal bond cases brought in federal diversity courts. In a series of nineteenth-century decisions, the Supreme Court authorized federal diversity courts to enforce payment on municipal bonds even when such bonds would not have been enforceable as a matter of state law. ${ }^{165}$ The Cour's rationale for ignoring state substantive law in most of these cases was not the Contracts Clause, however, because the impairment in those cases did not arise legislatively (as required by the Clause). ${ }^{166}$ Instead, the impairment arose from state judicial pronouncements about the propriety of the issuance of the bonds that were made only after the bonds were issued. ${ }^{167}$ The state cour decisions in these cases were often based on a holding that the municipality's original issuance of the bonds was illegal or unconstitutional under state law. During the era of Swift v. Tyson, ${ }^{168}$ however, federal diversity courts often followed their own lights in interpreting provisions in state constitutions so as to ignore intervening state decisional law and to enforce the earlier contracts to pay on the bonds on the basis of principles of "general constitutional law."16y

of any tax, fine, or amercement assessed against the sald Deshler")

163. See id. at 634 (Catron, J., dissenting) (charactenzang the procoedings as "disrepulable" beciase the assignment made it possible for the out-of-stater to swear that he was not being ustraned for taxes)

164. The majority principally addressed the Assignee Clause assues See id at 630-32

165. See generally BRIDWELL \& WHTTEN, supra note 44, at 116-19 (critcizing the Court's municipal

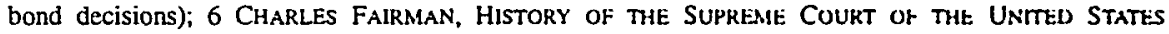
RECONSTRUCTION AND REUNION 918-1009 (1971) (discussing the mumicipal bond cases). HOVENKAMP. supra note 10, at 90-91 (same): Powe, supra note 8. at 753-56 (viewing the municipal bond cases as precursors to substantive due process).

166. See CURRIE, supra note 60, at 220-21 (disagreeing with CARL SwISHER, HISTORY OF THE SUPREME COURT OF THE UNITEd STATES 335 (1974), which interpreted Gelpke + Cin of Dubuque. 68 U S (1 Wall.) 175 (1863), as indicating that judicial abrogations volated the Contracts Clause); 6 FAIRsids, supra note 165, at 937 (noting Justice Taney's analogizing between judicial and legıslatuve imparments. but also noting that the Coun had consistently limited Contracts Clause cases to statutes), Powc, supra note 8 , at 740 (noting that the municipal bond cases typically presenied no federal questions). see also WRIGirT. supra note 60 , at 80 (stating that it was not clear that the Court invariably adhered to its prunciple that a state judicial decision cannot impair a contract). State courts thus were free not to cnforte the bonds, while federal cours generally did enforce them. See Riggs v. Johnson County. 73 U S (6 Wall) 166. 167 (1867) (statement of the case) (noting the different courses followed by state and federal courts)

167. The differences between cases that presented Contracts Cliuse claims and those that did not. however, could be quite slight. Compare Bank of W. Tenn. Y. Cillzens' Bank, 81 U S (14 Wall) 9 (1871) (holding that a section 25 case was not presented where the Loustana Supreme Court had relied both on prior cases and on a subsequent state consututional provision abrogating transactions in confedefate currency), with Delmas v. Insurance Co., 81 U.S (14 Wall) 661.665. 667 (1871) (taking revicw and finding a Contracts Clause violation when the Loussiana Supreme Court relied on the state constitution to refuse enforcement of a contract based on confederate money) The Supreme Coun in Delorus noted that it had denied review where the state court decision found the contracts voud by relying on public policy See id. at 667-68.

168. 41 U.S. (16 Pet.) 1 (1842).

169. See generally PAUL BREST \& SANFord LEVINSON, PhOCESSES of ConstTtutional DECISIONMAKING 102-10 (3d ed. 1992) (discussing theones of vesied righis and nonretroativity denved from natural law that the Court applied in non-section 25 cases). Powe, supra note 8, at $7+2$ (same) 
The federal courts, however, did not merely deviate from state courts as to their rules of decision, but also as to the underlying causes of action to remedy the bond defaults. In some states, a mandamus action commanding an official to perform a nondiscretionary duty was the proper remedy to recover on defaulted municipal bonds. ${ }^{170}$ Federal courts outside of the District of Columbia, however, were powerless to grant original mandamus writs, ${ }^{171}$ and local government defendants in diversity actions to recover on bonds therefore argued that the federal courts could not grant relief. ${ }^{172}$ The Supreme Court got over these hurdles by allowing the action to be brought as a breach of contract action in federal court, ${ }^{173}$ with mandamus as a post-judgment (i.e., non-original) remedy. ${ }^{174}$ Thus, in addition to the rule of decision as to the validity of the contracts, the form of the underlying action at law was changed to accommodate federal jurisdiction in these cases that raised Contracts Clauselike concerns. ${ }^{175}$

At one level, the state and federal courts in the nineteenth century could be said to have been enforcing similar rights. After all, the primary duties to comply with contractual obligations (if not a particular contract) or not to take the property of another without legal justification were general principles. But the federal courts in both law and equity showed considerable independence as to procedures-including remedies - and with respect to standing-to-sue and

170. See, e.g., Davenport v. County of Dodge, 105 U.S. 237, 242 (1881) (discussing state statutory provisions for mandamus).

171. The Supreme Court had interpreted the Judiciary Act of 1789 to confer original mandamus jurisdiction only on the Supreme Court and further held the particular provision an unconstitutional attempt to expand the Supreme Court's original jurisdiction. See Marbury v. Madison, 5 U.S. (1 Cranch) 137, 17576 (1803); see also M'Intire v. Wood, II U.S. (7 Cranch) 504 (1813) (holding that Congress had not granted lower federal courts the power to issue mandamus). Thus, outside of the District of Columbia, no federal court could issue an original mandamus writ. See Riggs v. Johnson County, 73 U.S. (6 Wall.) 166, 197 (1867) (stating that only the District of Columbia Circuit Coun could issue mandamus as an exercise of original jurisdiction).

172. See, e.g., Riggs, 73 U.S. (6 Wall.) at 178-79 (argument of defendant), 188-89; Board of Comm'rs v. Aspinwall, 65 U.S. (24 How.) 376, 377-78 (1860) (argument of plaintiffs).

173. See Davenport, 105 U.S. at 242 (allowing suit on a contract and rejecting the argument that original mandamus was the only remedy available under statutes creating the liability); $c f$. County of Greene v. Daniel, 102 U.S. 187, 195 (1880) (stating that although mandamus would lie in state courts without first reducing bonds to judgment, "[a] suit therefore, to get judgment on the bonds or coupons is part of the necessary machinery which the courts of the United States must use in enforcing the claim, and the jurisdiction of those courts is not to be ousted simply because in the courts of the State a remedy may be afforded in another way").

174. The Court relied on the authority of the All Writs Act, as well as on the federal courts' ability to adapt state process to their needs under the process acts providing for adoption of state procedures. See. e.g., Aspinwall, 65 U.S. (24 How.) at 384 (relying on All Writs Act); see also Riggs, 73 U.S. (6 Wall.) at $194,197-98$ (stating that while only the District of Columbia court can issue original writs of mandamus, other federal courts can issue them in aid of an existing jurisdiction); id. at 207 (Miller, J., dissenting) (noting that mandamus is an original action under lowa law).

175. When there were legislative impairments, the municipal bond cases unproblematically involved Contracts Clause problems. See, e.g., Louisiana v. Pilsbury, 105 U.S. 278, 302 (1881) (holding legislative repeal of mandamus remedies against municipal officials violative of the Contracts Clause); $c f$. Chicot County v. Sherwood, 148 U.S. 529 (1893) (holding that a state statute requiring litigants to present bonds to a county court was inapplicable to federal diversity litigants, in part to avoid a potential Contracts Clause problem). 
other elements of underlying causes of action. This independence undermines a characterization of diversity cases in which federal constitutional issues were raised as basically state law claims with federal issues interjected only "interstitially."176

\section{Constitutional Questions in State Courts}

Federal questions also arose in another context-that is, in the state courts. This part seeks to determine the extent to which the Supreme Cour forced remedies for constitutional violations on state courts. Although the Court generally reviewed constitutional issues only as they arose in the context of state-created remedial rights, it occasionally compelled the states to provide remedies in the nature of trespass against state officers. This occasional remedy-forcing in turn sheds light on the modern jurisprudence of constitutionally compelled remedies, discussed further in Pan III.

Section II.A first discusses the ordinary Supreme Cour practice of reviewing federal questions only as they arose within a framework of statecontrolled remedial rights. Then, this section shows how the Coun deviated from its normal practice of taking the state courts as it found them in Contracts Clause litigation between private parties. In such cases, Section II.B shows, the Court on direct review required state courts to maintain remedies substantially equivalent to those that had been in force at the time a contract was entered. Because of sovereign immunity concerns, however, the Coun did not force the state courts to maintain remedies against the states themselves for violations of the states' own contracts-in contrast to the requirement that states maintain equivalent remedies in private Contracts Clause litigation. In particular, the Court would not strictly require a state to maintain actions for "affirmative" relief against itself or its officers that had been available at the time of contracting, such as suits for money damages against the state itself or for mandamus against officers to compel their acceptance of state notes for payment of state taxes. Thus the state debt cases appeared to follow the normal section 25 model of according states great deference in the provision of remedial rights in their own courts.

Despite this deference to state remedial frameworks, the Supreme Court nevertheless required the states to continue to maintain trespass remedies against individual officers who made seizures after laxpayers tendered

176. The magnitude of the deparure of federal actions from stale dettons as difticult to determune As discussed supra note 120 , this Article's exploration of the differences generally locuses on cases in which parties raised some question as to why state reyuirements were ignored Although dilterences in enforcement of judgments and of equitable remedies. and even of mandamus. affected many ctses, there may be countless cases were there were no substanlial dilferences between stale und lederal attions When such issues arose, however, the Supreme Coun had litue trouble tgnonng state law that obstructed tederal relief. 
abrogated governmental debt in payment of state taxes. This result suggests that the Court saw trespass actions against individual officers to redress exactions under unconstitutional laws as constitutionally compelled. The diversity action raising federal questions and the compelled state law action together suggest the existence of a baseline of required remedies against state officers, a baseline which in turn gave rise to nondiversity federal question actions, as discussed in Part III.

\section{A. Taking the State Courts as They Were}

The flip side of the federal diversity courts' following their own versions of procedures, remedies, standing, and other elements of claims, was that states were similarly free to shape claims in their own courts. Supreme Court review of state court judgments was limited to matters respecting the immediate federal issues raised in a case, meaning that nonfederal issues were ordinarily off-limits. ${ }^{177}$

To be sure, the Court sometimes reviewed-as it does now-the adequacy of the state law grounds that appeared to support the judgment to assure that state courts were not unfairly applying state law to defeat federal rights. ${ }^{178}$ This was particularly true in Contracts Clause cases where state courts frequently based their conclusions that state legislation did not impair a contractual obligation on a holding that there had never been an enforceable contract. ${ }^{179}$ But even taking into account such occasional exploration of state law issues, the paradigm case for direct review was one in which the state court (fairly applying its own law) would have granted relief but for the fact that it found against the federal rights claimant on the merits of his or her federal claim. Federal law was therefore operative of its own force in state courts, in terms of providing rules governing primary behavior. But the form of remedial rights remained largely within state control. Thus, on direct review, the Supreme Court took the state courts as it found them in terms of the shape of remedial rights much the same way that it does now, ${ }^{180}$ with federal

177. See supra note 79 and accompanying text; $c f$. G. EDWARD WHITE, THE MARSHALL COURT AND Cultural CHANGE 657-59 (1991) (noting that it was only in non-section 25 cases that the Court could evoke principles of general as well as constitutional law).

178. See, e.g., Martin v. Hunter's Lessee, 14 U.S. (1 Wheat.) 304 (1816) (reversing the state court's refusal to obey the mandate in Fairfax's Devisee v. Hunter's Lessee, 11 U.S. (7 Cranch) 603, 622-26 (1813), which held that land had not escheated under state law prior to the effective date of a treaty protecting land titles of British subjects).

179. See generally Alfred Hill, The Inadequate State Ground, 65 COLUM. L. REv. 943, 954-55 \& n.43 (1965) (stating that the first case in which the Supreme Court directly asserted its gencral authority to review the adequacy of state grounds actually passed on by the state court was Chapman v. Goodnow's Administrator, 123 U.S. 540 (1887), but citing prior instances of review of state grounds, including in Contracts Clause cases).

180. See Hart, supra note 17, at 508 (stating that in enforcement of federal rights, "[t]he general rule, bottomed deeply in belief in the importance of state control of state judicial procedure, is that federal law takes the state courts as it finds them"). 
judicial review directed primarily to the interstitial federal element. ${ }^{\text {ss }}$

\section{B. Taking the State Courts as They Once Were}

On occasion, however, the Supreme Court would not defer to the states' structuring of their own causes of action and remedies. Instead, it sometimes compelled states to retain certain common law remedies. This was particularly true in litigation involving Contracts Clause issues.

\section{Private Contracts Clause Litigation}

The Supreme Court, in addressing state debtor relief legislation challenged as unconstitutional, had generally required that states maintain remedies substantially equivalent to those in effect at the time the underlying contract was entered into. ${ }^{182}$ Under these principles, a state might be forced as a matter of federal law to restore remedies that the legislature had repealed or modified. For example, in Louisiana 1: Pilsburn, ${ }^{183}$ the Cour on direct review of a suit to recover on municipal bonds treated the legislative repeal of mandamus remedies against city officials as a nullity; the change in remedy itself violated the Contracts Clause. The Court directed the state court to issue a writ of mandamus ${ }^{184}$ and thus effectively to apply the same remedy as if the repeal had never occurred. Such cases requiring the state courts to supply previously existing remedies took the state courts not as they were but as they had been at the time the contract was formed. Of course, in so doing, the Court did not force entirely new remedies on the states, but simply required them to supply older ones.

\section{State Bond Litigation}

The requirement that the states maintain remedies as effective as those operative at the time of contracting was, however, more problematic when the

181. See id. at 507 ("The supremacy clause, of course, makes plain that if a state coun undertakes to adjudicate a controversy it must do so in accondance with whatever tederal law is applicable ")

182. See, e.g., Edwards v. Kearzey, 96 U.S. 595 (1878) (holding a homestead exemption unconstitutional as applied to preexisting contracts): Lessee of Ganlly v. Ewing, th U S (3 How 707 (1845) (invalidating the application to previously entered contracts of a statute providing that mongaged propeny could not be sold for less than one-half of apprased value). Bronson y Kinac. +2 U S (I How) 311 (1843) (invalidating as to previously existing contracts a state statute requinng that judicial sules of a judgment debtor's property be for at least two-thirds of ats apprased value). ser also Hovt.:kx.stP. supra note 10, at 24-25 (noting that, prior to 1934, the Coun struck down every substantial moditication of the debtor-creditor relationship that was made retroacuve). WRIGHT, supra note 60. 51 70-71 (discussing additional authority and noting that the rule of Bronson remaned settled doctrine untul at lesst 1934). ad at 106 (noting that although the Coun sustanned some legislation that regulated the debtur-creditur relationship, such legislation was not strictly speaking for the purpose of giving reliel to debtors)

183. 105 U.S. 278, 301-02 (1881).

184. See id. at 302. 
state itself, rather than an individual or municipality, was the defaulting contracting party. ${ }^{185}$ As a historical matter, the scope of enforceable contractual rights against the state was always something of a conundrum. ${ }^{186}$ Certain kinds of state abrogations of their own contracts were clearly violations of the Contracts Clause and were just as clearly judicially remediable. For example, legislative abrogation of an explicit promise not to tax a business or not to license a competing business would violate the Contracts Clause and could be enforceable by remedies against collection officials or the competing business, respectively. ${ }^{187} \mathrm{~A}$ bare promise of a state to pay money, however, was less clearly guaranteed by the Contracts Clause, partly because of the problem of remedies against sovereigns, ${ }^{188}$ but also because of the nature of the promise itself. ${ }^{189}$ The Supreme Court frequently stated that persons who

185. See Beers v. Arkansas, 61 U.S. (20 How.) 527, 530 (1857) (holding on review of an action to recover interest on state-guaranteed bonds that a state could impose additional requirements for suit against the state). The Court reasoned that the state's waiver of the privilege of sovereignty was voluntary and could be withdrawn, and that the prior law under which suits against the state did not require filing the bonds was not a contract but general legislation. See id. at 529-30.

186. See Fallon \& Meltzer, supra note 119, at 1790 n.317; see also Martha A. Field, The Eleventh Amendment and Other Sovereign Immunity Doctrines (pt. 1), 126 U. PA. L. REV. 515, 529 (1978) (noting Alexander Hamilton's position that debts were binding only "on the conscience of the sovereign").

187. See, e.g., The Binghamton Bridge, 70 U.S. (3 Wall.) 51, 82 (1865) (upholding a Contracts Clause claim on behalf of the Chenango Btidge Company in a suit to enjoin the Binghamton Bridge Company in state court); Deshler v. Dodge, 57 U.S. (16 How.) 622 (1853) (finding a Contracts Clause violation when the state seized bank notes to collect taxes at a rate higher than that promised under an 1845 state bank chartering statute); see also WRIGHT, supra note 60 , at 143 (discussing claims against competing businesses). The Supreme Court, however, beginning in the Taney years, was reluctant to find that a governmental charter granted monopoly privileges. See Charles River Bridge v. Warren Bridge, 36 U.S. (11 Pet.) 420 (1837); see also HovENKAMP, supra note 10, at 11, 24-25 (stating that the Taney Court's public Contracts Clause cases reflected the classical view that a state could best develop private enterprise by leaving enterprise alone, free of both regulation and subsidies); Stephen A. Siegel, Understanding the Nineteenth Century Contract Clause: The Role of the Property-Privilege Distinction and "Takings" Chuse Jurisprudence, 60 S. CAL. L. REv. 1, 31 (1986) (stating the general principle mandating strict construction of corporate charters). Eventually the Court held that a charter giving a railroad the power to determine reasonable rates was subject to the state's power to determine that the rates were reasonable. See HOVENKAMP, supra note 10, at 31, 34-35 (discussing the Railroad Commission Cases, including Stone $v$. Farmers' Loan \& Trust Co., 116 U.S. 307 (1886); Stone v. Illinois Central Railroad, 116 U.S. 347 (1886); and Stone v. New Orleans \& Northeastern Railroad, 116 U.S. 352 (1886)). The Contracts Clause thus did not end up substantially interfering with state regulation of monopolies. See id. at 31-33. In addition, reservation clauses in charters would allow states to abrogate prior grants prospectively without violating the Contracts Clause. See Siegel, supra, at 30 (stating the general principle that a corporate charter would be subject to legislative modification if the charter contained a reservation clause).

188. See, e.g., Board of Liquidation v. McComb, 92 U.S. 531, 536 (1875) (noting that "there arc many constitutional provisions mandatory upon the legislature which cannot be directly enforced,- - the duty, for example, when creating a debt, to provide adequate ways and means for its payment"); David P. Curric, Sovereign Immunity and Suits Against Government Officers, 1984 SUP. CT. REV. 149; David E. Engdahl, Immunity and Accountability for Positive Government Wrongs, 44 U. COLO. L. REv. 1, 15-17, 33 (1972) (describing officer liability as derived from agency law that made agents liable for their own torts but not for contracts on behalf of known principals).

189. The Framers of the Contracts Clause had been principally concerned with governmental abrogation of private contracts. See WRIGHT, supra note 60 , at 15 ; see also HoVENKAMP, supra note 10 , at 18-19 (noting that, despite the Framers' concern with private contracts, by the Taney period the Clause had become the principal federal limitation on states' power over corporations). 
borrowed from a sovereign relied only on the good faith of that government. ${ }^{190}$

\section{a. Auxiliary Promises}

So widespread was the uncertainty whether a state's mere promise to pay was enforceable that very few suits ever appear to have sought such direct payment from the state. ${ }^{191}$ Rather, litigation 10 enforce state contracts generally concerned what may be called "auxiliary" promises. To enhance its creditworthiness, a state sometimes made additional promises to its creditors: Not only would it promise to repay its debts, but it might also promise that there would be remedies against it or its officers if it defaulted. ${ }^{192}$ In such a scheme, the state might provide for lawsuits directly against the state, or it might impose statutory duties on state officers to accept government bond coupons (or other state-guaranteed debt) in payment of taxes or other obligations of the citizen to the government. The duties on state officers to accept the government coupons would typically be made enforceable under state statutes by mandamus. Under such a scheme, the taxpayer could bring a mandamus action against the officer to compel acceptance of the coupons or notes after the officer refused a tender of them in payment of taxes. But if, after refusing the paper, the officer proceeded immediately to seize property in payment of state taxes without awaiting the mandamus action, the taxpayer could then bring the traditional common law trespass remedy against the officer for his unjustified seizure of propeny. ${ }^{193}$

As discussed below, ${ }^{194}$ the Court seemed inclined to recognize breaches of these additional or auxiliary promises as Contracts Clause violations, even

190. See, e.g., Marye v. Parsons, 114 U.S. 325, 328 (1884) (indicalung that 1 govemment's tulure to honor its promises was a damnum absque injurio). Poindexter $v$ Grenhow, 11.4 US 270. 279 (1584) (stating as to a set of bonds, for which later bonds with coupons recesvable for tuxes had been exchanged. that "[t]he only security for their performance was the public fath"). Bank of Wash $r$ Arkans.s. 61 U S (20 How.) 530, 532 (1857) ("Those who deal in the bonds and obligations of a soveretgn State are aware that they must rely altogether on the sense of justuce and good fath of the State. and that the judiciary of the State cannot interfere to enforce these contracts without the consent of the State, and the courts of the United States are expressly prohibited from exercising such a junsdiction "). see also Vicki $C$ jackson. The Supreme Court, the Eleventh Amendment, and State Soverergn Imumunn, 98 YaLt: L J 1. 124 n +44 (1988) (citing authority that the Contracts Clause was not intended to allow affirmaltve reliel against the states)

191. See, e.g., Louisiana v. Jumel, 107 U.S. 711.721 (1882) (noung that the parties drouded asking directly for payment). But see Hans v. Louisiana, 134 U S. I, 1 (1890) (rejectung sut by a Louistana cilıeen to recover the amount of coupons annexed to bonds): Beers y Arkinsas. 61 U S (20 Huw) 527.529 (1857) (rejecting a covenant action brought in state court to recover interest on bonds where the state had allowed suits against itself but later added extra requirements that the plistint had not met)

192. See, e.g., Furman v. Nichol, 75 U.S. (8 Wall.) 44, 59 (1868) ("[T]he [state] legislature, in its anxiety to insure for these notes a still greater confidence of the community provided that they should be receivable . . by all tax collectors ....").

193. See, e.g., Poindexter, 114 U.S, at $279-80$ (noung that the recelvibulity of coupons for state taxes was a valuable consideration, giving a self-executing remedy to the creditor and imposing $\downarrow$ leg $\downarrow$ duty on the tax collector to receive the coupons).

194. See infra text accompanying notes 199-203 
when it might not have enforced a state's simple promise to pay. ${ }^{195}$ Nevertheless, the Court did not require the state to maintain strictly equivalent remedies in such cases as it did in Contracts Clause cases involving nonstate debtors. Illustrating the rigor of the requirement of equivalent remedies in private-contract cases was the Court's invalidation, as to previously existing contracts, of a state statute that required judicial sales of the judgment debtor's property to be for at least two-thirds of its appraised value. ${ }^{196}$ By contrast, in state-as-debtor cases, the Court allowed the states to dilute preexisting remedies significantly-particularly those remedies that had been available against the state itself and against its officers for mandamus. This allowance of dilution of remedies reflected the ambivalence surrounding enforceability of state debt obligations. States did not completely escape remedies for breaches of auxiliary promises, but their remedial freedom was considerable.

Historically, the abrogation of a state's contracts involving auxiliary promises took a variety of forms. In a typical scenario, the state legislature left intact causes of action against itself or its officers, but simply legislated that the state would no longer recognize a particular obligation, or that its officers should no longer accept particular government paper in payments to the state. ${ }^{197}$ In such cases, if the state court denied relief on the merits of the Contracts Clause claim by erroneously holding that the new legislation did not impair the obligation of contract, the Supreme Court would simply reverse the state court decision on the merits. ${ }^{198}$

For example, the Tennessee legislature provided that the bills of the Bank of Tennessee would be receivable by all tax collectors in payment of moneys due the state, ${ }^{199}$ but the legislature subsequently repealed the statute. ${ }^{200}$ The state court mandamus remedy to compel officers to perform plain duties,

195. See, e.g., Woodruff v. Trapnall, 51 U.S. (10 How.) 190, 206-09 (1850) (holding that the state could not withdraw its promise to accept notes of the Bank of Arkansas in payment of debts owed to the state).

196. See, e.g., Bronson v. Kinzie, 42 U.S (1 How.) 311 (1843); cf. Chicot County v. Sherwood, 148 U.S. 529 (1893) (holding that a federal diversity suit on county bonds could go forward despite the plaintiff's failure to comply with a state law requirement of presentation of bonds to the county court); $i d$. at 534 (stating that, if the presentation requirement, which was enacted after the issuance of the bonds, were applicable, "it would present a very grave question whether it was not such a substantial and matcrial change in the remedy... as to impair its obligations").

197. See, e.g., Woodruff, 51 U.S. (10 How.) at 191 (addressing Contracts Clause claims where an 1836 statute provided that notes of the Bank of Arkansas would be receivable in payment of debts due the state, while an 1845 statute provided that only undiscounted, par funds would be received).

198. See Curran v. Arkansas, 56 U.S. (15 How.) 304, 309, 315 (1853) (holding that the Supreme Court could entertain a suit for an equitable decrec to restore capital stock to a bank that the state by legislation had withdrawn, where Arkansas courts had held the state amenable to suit); Woodruff, 51 U.S. (10 How.) at 190 (reversing the denial of mandamus by the Arkansas Supreme Court to compel the state treasurer to accept since-repudiated state bank notes in payment of judgment). The Court in Woodruff also stated that the Arkansas Supreme Court had exercised jurisdiction, and added, "To that court exclusively belongs the question of its own jurisdiction." Woodruff, 51 U.S. (10 How.) at 209.

199. See Furman v. Nichol, 75 U.S. (8 Wall.) 44,45 (1868) (statement of the case).

200. See id. at 46 . 
however, still existed; the legislature had only attempted to change what those plain duties were. When a state tax collector thereafter refused a taxpayer's tender of Bank of Tennessee bills, the taxpayer sued the official for mandamus. The state supreme court denied relief on the merits, effectively finding no Contracts Clause violation in the repeal of the officer's duty to accept the bills in payment of taxes. ${ }^{201}$ On direct review in Furman 1 . Nichol, however, the U.S. Supreme Court found a Contracts Clause violation and remanded with directions to enter a judgment awarding the writ of mandamus. ${ }^{32}$ The Cour thus decided the Contracts Clause issue as it arose within the still-intact state remedial framework, a framework that provided for mandamus remedies against collectors who failed to perform nondiscretionary duties, even if state legislation had (unconstitutionally) attempted to repudiate a particular duty. ${ }^{203}$

\section{b. State Remedial Manipulation}

State legislatures eventually perceived that they might repudiate contractual obligations more effectively by repealing certain preexisting causes of action against the states and their officials, rather than merely legislating that particular obligations should no longer be honored by them. ${ }^{20}$ Here the states were more successful in evading their promises.

The Supreme Court seemed most lenient when the abrogated state law remedy was one that would have run against the state in its own name. On section 25 review, the Court did not require the state to reinstate creditors' remedies against the state that the state had previously made available against itself but had subsequently withdrawn. ${ }^{205}$ The Cour evaded its requirement that the state maintain remedies as effective as those existing at the time of contracting by questioning whether the state's allowance of remedies against itself had been a part of the original contract with the state, or whether such remedies had really been available at the time of contracting. ${ }^{3 \infty}$ For example.

201. See id. at 59.

202. See id. at 62-64.

203. Cf., e.g., Hanman v. Greenhow, 102 U S 672.685 (1880) (reversing a stale cuuri's denial of mandamus where the state legislature had changed the duties of the treasurer so that he was not to take the coupons without deducting taxes on the bonds to which they had been altached), see also Woodruff. 51 U.S. (10 How.) at 190, 207-09 (reversing a state court's dental of mandamus agannst the state treasurer)

204. See Antoni v. Greenhow, 107 U.S. 769, 770-71. 779 (1882) The Coun in Anton described how state legislation initially made bond coupons receivable for payment of state taxes, see ad at 770, but subsequent legislation forbade state officers from acceplang the coupons The Virginas Supreme Court ot Appeals and the U.S. Supreme Coun treated the later legislation as invalid and entorced the duty of stute officers to accept the coupons by mandamus. See id. at 771 The stale legislature then elfectuvely abrogated the mandamus remedy. See id. at 771-74; see also mfra notes $215-218$ and accompunying text

205. See, e.g., Railroad Co. v. Tennessec, 101 U S 337.340 (1879)

206. See id. at $339-40$ (holding that where remedies against the state that had existed at the tume ot formation of the contract required appropriations, "l was not a Contracts Clause volation to repeal them). see also Baltzer v. North Carolina, 161 U.S. 240, 245 (1896) (finding no volation of the Contracts Clause in the repeal of a statute providing that the state supreme coun could make non-binding decisions in claims against the state); Railroad Co. v. Alabama, 101 U.S 832.834-35 (1879) (finding no Contracts Clause 
the Court held in one case that the legislative repeal of a statute providing for seemingly enforceable judgments against the state was not a Contracts Clause violation even as to contracts entered while the statute was in force. ${ }^{207}$ The Court somewhat unconvincingly reasoned that because the state constitution provided that no money could be drawn from the treasury without an appropriation, the state had never actually made a judicially enforceable promise. $^{208}$

The Court also allowed the repeal of mandamus remedies against state officers in some circumstances. In such cases, the Court often found that the state had substituted a new remedy substantially equivalent to the repealed mandamus remedy, even though the new remedy was often more burdensome. For example, subsequent to the litigation in Furman v. Nichol, ${ }^{209}$ the Tennessee legislature substituted a post-payment refund remedy in place of a pre-payment mandamus remedy that would have compelled the state officer to accept Bank of Tennessee notes in payment of state taxes. ${ }^{210}$ This time the state was successful. The Supreme Court upheld the denial of the mandamus remedy, reasoning that the state had provided an effective substitute. ${ }^{211}$ Thus, the state was able to effect substantial remedial changes concerning its own contracts in a manner that would have been forbidden in the context of private contracts, where only the most modest remedial changes were acceptable. ${ }^{212}$

\section{c. The Example of the Virginia Coupon Cases}

Cases arising out of Virginia's post-Reconstruction debt repudiation illustrate the extent to which the Supreme Court would and would not defer to the state remedial framework in sovereign debt cases. ${ }^{213}$ Virginia had refunded its governmental debt with bonds whose interest coupons the state tax

violation in the repeal of a statute providing for seemingly enforceable judgments against the state, because the state constitution provided that no money should be drawn from the treasury except by appropriation).

207. See Railroad Co. v. Tennessee, 101 U.S. at 339-40.

208. See id. at 340.

209. 75 U.S. (8 Wall.) 44,45 (1868).

210. See Tennessee v. Sneed, 96 U.S. 69, 70-73 (1877) (upholding on section 25 review Tennessee's repeal of a mandamus remedy that had previously been available to compel acceptance of Bank of Tennessee coupons for taxes under state law where the state had substituted a post-payment refund remedy), described in Antoni v. Greenhow, 107 U.S. 769, $799-800$ (1882) (Field, J., dissenting) (distinguishing the Court's allowance of repeal of remedies in Sneed on the ground that the Tennessee Court had said that no mandamus was available at the time the contract was entered to compel receipt of the Bank of 'Tennessee's bills in payment of state debt).

211. See Sneed, 96 U.S. at 73-75.

212. See Chicot County v. Sherwood, 148 U.S. 529, 534-36 (1893) (avoiding a Contracts Clause problem by not requiring county bondholders suing in diversity to comply with a later-enacted state law); see also WRIGHT, supra note 60, at 68-71, 104-09; sources cited supra note 182.

213. See Virginia Coupon Cases, 114 U.S. 269 (1884). Under this caption, the Court consolidated the following eight serially reported cases: Poindexter v. Greenhow, 114 U.S. 270 (1884) (main case); White v. Greenhow, 114 U.S. 307 (1884); Chaffin v. Taylor, 114 U.S. 309 (1884); Allen v. Baltimore \& Ohio Railroad, 114 U.S. 311 (1884); Carter v. Greenhow, 114 U.S. 317 (1884); Pleasants v. Greenhow, 114 U.S. 323 (1884); Marye v. Parsons, 114 U.S. 325 (1884); and Moore v. Greenhow, 114 U.S. 338 (1884). 
collectors were under a statutory duty to accept in payment of state taxes in lieu of cash. At the time the coupons were issued, the tax collector's obligation to accept them could be enforced by the taxpayer in state cour by a suit for mandamus, as well as by a tort action if the collector seized a taxpayer's property to satisfy a tax after he had tendered the coupons and the collector refused to accept them. Subsequently, however, the Virginia legislature repudiated the receivability of the coupons for taxes and the duty of the officer to accept them, but it did not repeal the mandamus remedy against the officer. On direct review of a state court case denying mandamus against a collector, the U.S. Supreme Court reversed the denial of relief on the merits. Just as it had previously done in Furman regarding Tennessee's contractual repudiation, the Court treated the post-contractual legislative repeal of the specific duty of the officer as a Contracts Clause violation and ordered relief within the unrepealed state mandamus framework. ${ }^{214}$

Later, however, the Virginia legislature added a requirement to the mandamus remedy that the taxpayer first pay the taxes in cash, and then petition a state court for recognition of the validity of the coupons. ${ }^{215}$ This time, when taxpayers sought mandamus in the state courts without complying with the new provisions and the Virginia courts denied relief, the Supreme Court affirmed. ${ }^{216}$ In so doing, the Court allowed the legislature effectively to replace the mandamus action with a burdensome post-payment refund action, reasoning that the refund remedy was substantially equivalent to the previous mandamus remedy. Thus it concluded that there had been no impairment of the obligation of contracts. ${ }^{217}$ The result, if not the explicit reasoning of the Court, was that the states were given leeway to weaken or repeal affirmative remedies against themselves and their officers. ${ }^{218}$ The idea that the states could not be held strictly to promises to pay out money or

214. See Harman v. Greenhow, 102 U.S. 672 (1880). Compare JUHN V ORTh. THE JUdiclal POWER OF THE UNTTED STATES-THE ELEVENTH AMENDMENT IN AMERICAN HISTORY 7-11 (1987) (allnbulung the Cour's Eleventh Amendment doctrine to a desire to make it difficult to enforce states' financial obligations in order to palliate the Southern states with the $1877 \mathrm{end}$ of Reconstruction), with Michael G Collins. The Conspiracy Theory of the Eleventh Amendment, 88 CoLUM. L. RFV 212. 218.39 (1988) (book review) (seeing continuity between the pre- and post-1877 doctrines)

215. See Antoni, 107 U.S. at 772-73, 775-76. The mandamus remedy was technic dlly avalable under the statute at issue in Antoni, but the taxpayer was requined to pay the tax with ordinary money and then file an action to try the validity of the coupons. See id. at $772-73$

216. See id. at 782. The Virginia Supreme Court of Appeals had been equally divided on the ussue and had denied relief. See id. at 774.

217. See id. at 775-78; see also Moore, 114 U.S. at 339-40 (relying on Anton to affirm the Vurgina court's denial of mandamus and remitting the planuff to remodies under the state stitute) In the Antont case, there were five Justices (including Stephen Ficld and John Harlan in dissent) who would have required substitutes for abrogated state mandamus remedies, and four who thought the state was free to abrogate the mandamus remedy without a substitutc. See Antom, 107 U S at 782, 801. 812

218. See Poindexter, 114 U.S. at 281 (describing Amom as a case "in which 1 was sought, by mandamus, specifically to enforce the contract of the State with the coupon-holder, by compelling. by affirmative action and process of law, the collector actually to receive the coupons tendered in salisfaction of taxes"). 
affirmatively to perform their promises had won out over the idea that the Contracts Clause required substantially similar remedies to those in effect at the time of contracting.

\section{d. Constitutionally Required Remedies}

The Court's deference to states in the provision of remedial rights against the state or its officials in state court, however, was not boundless, as the Virginia Coupon Cases $^{219}$ subsequently illustrated. At issue was not only the Virginia legislature's effective abrogation of mandamus remedies, as just discussed, but its further provision that no trespass action could be maintained against the collection officer for levying upon the property of a taxpayer who had tendered the coupons. ${ }^{220}$ In short, the legislature provided that the refund action was to be the exclusive remedy. In one of the cases, Poindexter $y$. Greenhow, ${ }^{221}$ a taxpayer who had tendered coupons sued the collector for damages in state court after the collector had rejected the tender and had seized the taxpayer's property to satisfy the tax. The Virginia Supreme Court denied relief because the state legislature had provided that no such cause of action existed against the collector. On review of this decision, the U.S. Supreme Court might have taken the route of saying, as it had in the mandamus cases, that the state-provided refund remedy was an adequate substitute for the trespass action. ${ }^{222}$ In Poindexter, however, the Court held that the tort action against the officer could not be repealed; ${ }^{223}$ instead, it directed the state court to make available to the taxpayer the trespass remedy against the officer. ${ }^{224}$

The Court's decision is significant for assessing the historical pedigree of constitutionally compelled remedies. To be sure, the Court's requirement that a state maintain the trespass action for damages could be viewed as merely restoring a state remedy that was effectively part of the state's contract at the time it was entered into. The Court in fact held that the repeal of the trespass remedies had itself worked an unconstitutional abrogation of the obligation of

219. 114 U.S. 269 (1884).

220. See Poindexter, 114 U.S. at 277. Antoni involved the validity of an act of January 14, 1882, which was effective from the date of passage. See Antoni, 107 U.S. at 771. The Virginia Coupon Cases involved an act of January 26, 1882, effective December 1, 1882, and an amendment of March 13, 1884, which more thoroughly repealed prior remedies. See Poindexter, 114 U.S. at 273-76.

221. 114 U.S. 270 (1884).

222. See Antoni, 107 U.S. at $776-77,782$ (effectively allowing the substitution of a post-payment refund for a pre-payment mandamus remedy, but reserving the issue of whether the treasurer would be liable in trespass if he refused the tender and distrained the taxpayer's property). But cf. Poindexter, 114 U.S. at 299 (rejecting the argument that, in view of the refund remedy, the case was ruled by Antoni).

223. See 114 U.S. at 302-03; see also Chaffin v. Taylor, 114 U.S. 309, 310 (1884) (reinstating on the basis of Poindexter a trespass action that had been dismissed by a state court).

224. The Cour reversed and remanded "with directions to render judgment upon the agreed statement of facts in favor of the plaintiff." Poindexter, 114 U.S. at 306. The Coun had allowed adequate substitutc remedies to supersede others in Contracts Clause jurisprudence. The result in Poindexter seemed to have been implicitly based on the inadequacy of the refund remedy, although the Coun had held earlier that the refund action was an adequate substitute for the mandamus remedy. See id. at 280. 
contract and thus the repeal could be ignored. ${ }^{225}$ It reasoned that general tor remedies continued to exist in Virginia, such that if one ignored the unconstitutional abrogation of remedies against the collector, the background tort remedy would remain and was enforceable against the collector. ${ }^{26}$ But more importantly, the Court also indicated that the state had to make available such general tort remedies in the first place: "No one would contend that a law of a State, forbidding all redress by actions at law for injuries to property, would be upheld in the courts of the United States, for that would be to deprive one of his property without due process of law."227 The Court therefore suggested that a remedy for trespass in such cases was constitutionally compelled, quite apart from the Contracts Clause issues implicated by the repeal of such remedies.

The Virginia Coupon Cases are traditionally read as holding that the defense of sovereign immunity is unavailing when the plaintiff can allege a tort against an individual officer. ${ }^{228}$ But this focus on immunity may obscure the Court's related suggestion that the existence of the common law tort action for certain types of official invasions of liberty or properiy may itself be a constitutional requirement. ${ }^{229}$ The Supreme Court's response to Virginia's abrogation of bonds, together with other decisions involving state promises to pay, appears therefore to present a hierarchy of remedial resistance to state legislative and judicial abrogation. The following three subsections present this hierarchy, ranging from remedies always available to those often subject to state legislative repeal.

225. See id. at 303-04. By contrast, the Court had not required restoration of remedies in the mandamus cases, nor in cases in which the state previously had provided remedies agaunst itself See supra notes 204-212 and accompanying text.

226. See Poindexter, 114 U.S. at 282-83, 302.

227. Id. at 303; cf. Wilkinson v. Leland, 27 U.S. (2 Pet) 627.658 (1829) (finding no vested property rights that had been denied in the particular diversity case, but stating. "We know of no case, in which a legislative act to transfer the property of A. to B. without his consent, has ever been held a consututional exercise of legislative power in any state in the union."). But of Barron v Mayor of Ballimore. 32 U S (7 Pet.) 243, 247-48 (1833) (holding that the Fifth Amendment nght against uncompensaled takings was inapplicable to states).

228. See Currie, supra note 188, at 153 (treatung the Virguma Coupon Cases as exemplifying personal liability and agency principles in tor); Engdahl, supra nolc 188, at 26-27 (discussing the Virginua Coupon Cases in relation to sovereign immunity doctnne).

229. See Poindexter, 114 U.S. at 303: see also Hill, supra note 113. at 1132 (statung that while "the Constitution was to be implemented in accordance with the remedial instututions of the common law; and the common law ... was peculiarly within the province of the state 11 does not follow that the state was necessarily to be master of the action in (respass founded upon unconstututional behavior"), id at 1133 . 34 ("[T]he fact that, by reason of the use of English procedural modes, a new federal nght might be pleaded only as the replication to a defense, did not mean that the declaration, which made no mention of the constitutional claim, was conclusive as to the sovereign source of the nght to recover"). Carlos Manuel Vázquez, What Is Eleventh Amendment lmumunity?, 106 Y ALE L.J 1683, 1778-79 (1997) (cilung Poindexser for the proposition that state courts can be required to give consututuonally necessary or appropnate remedies, even where state law denies a remedy); Louis E Wolcher. Sovereign Immuniry and the Supremacy Clause: Damages Against States in Their Own Courts for Conshituhonol Violahons. 69 Cal. L. REv. 189, 288 (1981) (same). 


\section{i. Defenses to Enforcement}

The most basic judicial remedy for constitutional violations was the ability to raise a defense to a government-initiated enforcement suit. ${ }^{230}$ If a state brought an enforcement action to collect unpaid taxes, the state courts' obligation to hear constitutional defenses would follow as a matter of course under the Supremacy Clause. ${ }^{231}$ Failure to hear the federal defense, or to hear and reject it, would occasion Supreme Court review. ${ }^{232}$ This aspect of the obligation of state courts to remedy unconstitutional state action is relatively unproblematic. ${ }^{233}$

\section{ii. Trespass Actions}

Some federal court scholars have concluded that judicial remedies are less imperative if the executive does not attempt to use the court system to validate its seizure of property. ${ }^{234}$ That is, when the legislature directs the use of extra-judicial enforcement mechanisms, it at least is not attempting to tell the courts to decide a case in a manner contrary to the Constitution (as it would if it purported to disallow the raising of a federal defense). ${ }^{235}$ Therefore,

230. See Hart, supra note 93 , at 1371-83, 1386-1401.

231. U.S. CONST. art. VI, cl. 2.

232. A procedural default would, however, be an adequate state ground that would support the judgment. See HART \& WECHSLER, supra note 1, at 576-83.

233. See, e.g., Case of the State Freight Tax, 82 U.S. (15 Wall.) 232 (1872) (invalidating a tax in a case brought in state court to collect taxes on articles passing through the state); Piqua Branch of State Bank v. Knoop, 57 U.S. (16 How.) 369 (1853) (sustaining a Contracts Clause claim based on an Ohio bank-chartering statute in an action in which the treasurer asked the court to help enforce payment of the tax); Nathan v. Louisiana, 49 U.S. (8 How.) 73 (1850) (allowing a Commerce Clause challenge to a license $\operatorname{tax}$ in an action filed by the state Attorney General claiming that the defendant was indebted to the petitioner for the amount of the license tax, but finding the tax constitutional); Brown v. Maryland, 25 U.S. (12 Wheat.) 419 (1827) (invalidating a license tax under the Commerce Clause on review of a case originally brought by indictment in the City Court of Baltimore). Defense to enforcement actions was a common form of challenges to business licensing taxes and other taxes alleged to be invalid under the Commerce Clause. See, e.g., Wabash, St. L. \& Pac. Ry. v. Illinois, 118 U.S. 557 (1886) (reviewing an enforcement suit tried on agreed facts and invalidating parts of a tax on Commerce Clause grounds); Webber v. Virginia, 103 U.S. 344 (1880) (invalidating a tax on peddlers sclling goods manufactured in other states in a case that originated by indictment); Osborne v. Mobile, 83 U.S. (16 Wall.) 479 (1872) (upholding a business licensing tax on review of a case in which a fine had been imposed for violation of the ordinance).

234. See, e.g., Fallon \& Meltzer, supra note 119, at 1826. Executive detentions of persons without the use of the courts, however, presumptively could be remedied by habeas. See U.S. CoNST. ant. 1, § 9, cl. 2. The Nonsuspension Clause, however, has generally been thought to extend only to extrajudicial detentions under federal authority. See HART \& WECHSLER, supra note 1, at 1368-71; Jordan Steiker, Incorporating the Suspension Clause: Is There a Constitutional Right to Federal Habeas Corpus for State Prisoners?, 92 MICH. L. REV. 862, 863 (1994) (acknowledging that the habeas writ was used in 1789 primarily to challenge unauthorized pretrial detentions). Professor Steiker nevertheless urges that the Suspension Clause and the Foureenth Amendment should be read together to mandate federal habeas review of convictions of state prisoners. See Steiker, supra, at 873 .

235. See United States v. Klein, 80 U.S. (13 Wall.) 128 (1872); Hart, supra note 93, at 1373 (stating that if Congress directs an Article III court to decide a case, Article III may provide a limitation on the power of Congress to tell the court how to decide it). 
these scholars have argued that the availability of judicial remedies for harms inflicted by government that have taken place without judicial process-i.e., affirmative judicial remedies sought by victims of official illegality-is not so clearly a constitutional necessity as is the ability to raise constitutional defenses to government-initiated enforcement actions. ${ }^{236}$ Indeed, the Supreme Court's insistence on such affirmative remedies may be criticized as judicial usurpation insofar as the legislature has not explicitly authorized such relief. ${ }^{237}$

Nevertheless, the Court appears to have treated trespass remedies against the wrongdoing governmental actor-with their deep roots in the common law-as existing independent of the will of the legislature ${ }^{238}$ and as resistant to state legislative and judicial uprooting. Indeed, the Court analogized the trespass remedy following a governmental invasion of liberty or property to a defense to an enforcement action. In Poindexter v. Greenhow, ${ }^{239}$ for example. it stated with reference to the trespass action that it forced on the state court, "Although the plaintiff below was nominally the actor, the action itself is purely defensive." 240 The Court clearly saw the federal defense to a state law cause of action and the trespass action as substantially equivalent. Neither seems to have been subject to state legislative repeal or judicial abrogation.

\section{iii. Positive Law Remedies}

Apart from trespass, however, other remedies more dependent on positive law for their existence were correspondingly more easily subject to state legislative repeal. Mandamus, as an action against officers as individuals, faced no sovereign immunity bar if brought in a proper case of failure to perform a

236. See, e.g., Fallon \& Meltzer, supra note 119 , at 1773 ; id at 1771 (notung that "[t]he tort plainuff is not thought to have a constitutional right to obtain relief agunst the govemment." due to the harm's having been previously inflicted).

237. See Bivens v. Six Unknown Named Agents of the Fod Bureau of Narcoucs, 403 U S 388, +12. 418, 422 (1971) (Burger, C.J., dissenting).

238. See Poindexter v. Greenhow, 114 U.S. 270. $302-03$ (1884); of. Greenwood v Freight Co, 105 U.S. 13,19 (188I) (noting that cours could enforce property nghts if the legislature provided no spectal remedy). In Greenwood, the Coun held that the state could repeal a corporation's charter because of a reservation clause and thereby take away powers of the company that depended solely on the chanter and that could not be exercised by unincorporated private persons. The Coun noted. however, that nghts to real and personal property were not by their nature dependent on the charter. See Greenwood. 10S U S. al 19: see also Westem Union Tel. Co. v. Call Publ'g, 181 U.S, 92, 101-02 (1901) (holding that while the state could not legislate as to an interstate transaction, it could apply the common law, which was nether state nor federal law but "those principles, usages, and rules of action applicable to the government and secunty of person and property, which do not rest for their authority upon any express or posutuve declaration of the will of the legislature"); HovenKAMP, supra note 10, at 82 (discussing the view of the Cours in cases such as Call Publishing that the common law was part of the invisible hand)

239. 114 U.S. 270 (1884).

240. Id. at 295. The Court continued, "Its object is merely to resist an attempted wrong and to restore the status in quo as it was when the right to be vindicated wias invaded. In this respect. It is upon the same footing with the preventive remedy of injunction in equity "Id. see also Hart, supra note 93, at 1383 (distinguishing plaintiffs trying to obtain the govemment's help from those tryng to protect themselves against extra-judicial govemmental coercion). 
nondiscretionary duty. But the propriety of such a remedy generally depended on state statutes that imposed a "plain duty" on the particular officer, as when states imposed specific requirements on officers to accept coupons for taxation. ${ }^{241}$ Even more dependent on positive enactment were actions against the state itself, as for payment on state-issued bonds. Insofar as suits against the sovereign were unknown at common law, the availability of such suits became "purely a question of local law depending on the Constitution and statutes of the state."242 The states were predictably more successful at dispensing with such positive-law-grounded remedies, even in cases where the positive remedies had been available at the time of contracting. But the trespass remedy against the officer subsisted, particularly when the legislature had abrogated effective substitute remedies. ${ }^{243}$ Thus, despite the lack of

241. See, e.g., Moore v. Greenhow, 114 U.S. 338 (1884); Antoni v. Greenhow, 107 U.S. 769 (1882). Poindexter reflected the Court's difficuities in deciding whether to treat mandamus like a trespass action against the individual officer or like a suit against the state itself. In Poindexter, the Court discussed its holding in Antoni that the refund remedy was an acceptable modification of the previously available mandamus remedy to compel acceptance of coupons without otherwise paying. Referring to its decision in Antoni, the Poindexter Court stated, "The court were not willing to decide that it was a suit against the State, in which the mode of proceeding could be modified, or the remedy taken away altogether, at the pleasure of the State." 114 U.S. at 280 . The Court nevertheless seemed to contrast the affirmativc mandamus remedy with the "defensive" trespass remedy, characterizing Antoni as a case "in which it was sought, by mandamus, specifically to enforce the contract of the State." Id. at 281 .

Injunctions in the nature of mandamus (as opposed to injunctions to stop a trespass) from the lower federal court had a checkered history. Where a plain duty had been created under state law (even if later repealed) and mandamus remedies had not been repealed, the Court seemed inclined to allow injunctions that had effects similar to mandamus. In Board of Liquidation v. McComb, 92 U.S. 531 (1875), for example, the Court entertained an action by an out-of-stater against officers on a state board to enjoin issuance of "consolidated" bonds at par, pursuant to recent legislation for payment of levee debt when under the prior legislative scheme others exchanged debt for consolidated bonds at $60 \%$ of prior debt. The initial funding bill had imposed duties on state officers, see id. at 533 , and a federal injunction was analogous to a mandamus to enforce plain official duties, see id. at 541 . The Court denied relief in a number of cases on review from lower federal courts where the litigants had not shown that the officers were under a plain duty under state law to perform the requested acts. See, e.g., Louisiana v. Jumel, 107 U.S. 711, 725-26 (1882) (denying relief where the state had repealed officers' duties to bond and coupon holders who were seeking the unusual relief of having the officers set aside funds for payment both in a mandamus suit that was removed from state court and in a similar equity suit in federal court). The Court in Jumel distinguished $M c C o m b$, which had concerned duties under the same act, by noting that the officers had specific duties in $M c$ Comb. See Jumel, 107 U.S. at 725-26; see also Marye v. Parsons, 114 U.S. 325. 328-29 (1884) (ruling that a holder of state coupons who owed no taxes to the state but had arranged with taxpayers to use the coupons in payment of their taxes had suffered no redressable injury). In Jumel, the Court arguably could have granted relief by reinstating a duty that the legislature had repealed (on the ground that the repeal itself violated the Contracts Clause), but the relief asked for in Jumel was somcwhat nonspecific. See Rolston v. Missouri Fund Comm'rs, 120 U.S. 390, 411 (1887) (granting injunctive relief and distinguishing Jumel on the ground that in the instant case the Court was compelling the officers to do what Missouri law required). The Supreme Court's treatment of federal court injunctions in the nature of mandamus contrasted with federal court injunctions against trespassory harms, where the federal courts paid less attention to state legislation. See, e.g., Allen v. Baltimore \& O.R.R., 114 U.S. 311 (1884) (affirming an injunction against a seizure to collect taxes after a tender of coupons).

242. Beers v. Arkansas, 61 U.S. (20 How.) 527, 529 (1857) (stating that, as a state's grunt of permission to be sued is altogether voluntary, it follows that the state may withdraw consent); see also Curran v. Arkansas, 56 U.S. (15 How.) 304, 309 (1853).

243. Cf. Fallon \& Meltzer, supra note 119, at 1787 (noting substitutability of remedies); Hart, supra note 93 , at 1366 (same). 
compulsory remedies against the state itself, a background of common law remedies provided a barrier against certain kinds of illegal state action. ${ }^{24}$

\section{Federal Question Cases and the Framework OF CONSTITUTIONALLy COMPELlED REMEDIES}

Thus far, this Article has discussed two tracks for potential remedies for violations of constitutional rights: federal cour diversity actions and actions in state court, including the Supreme Courts occasional forcing of remedial rights onto state courts. Section III.A discusses the emergence of nondiversity federal question cases as an additional track for constitutional remedies, running alongside the diversity action and the mandatory state cour trespass action. When it emerged, this additional avenue made it possible for persons who could not avail themselves of diversity to obtain remedies for constitutional violations as could diversity plaintiffs. This simultaneous emergence of compelled state law actions and federal question constitutional actions suggests that federal question actions should not be seen as emerging from state law causes of action to which federal ingredients had merely been added. Rather, both state and federal courts entertained trespass-type actions that were not grounded in each others' positive law, although such actions were in some sense constitutionally compelled. The federal question constitutional action seemed to derive less from state law actions and more from the tradition of federal courts' supplying remedial rights for constitutional violations in diversity without regard to state law limitations on remedies, as described in Part I.

This part next discusses how this "three-track" scheme operated. Section III.B describes it in the context of due process challenges to rate regulation,

244. My argument that cenain state remedies may be consututuonally compelled bears some afrinty to arguments made by Akhil Amar that state-law-sourced remedies should be avalable to remedy constitutional violations by federal officials. See, e.g., Alhil Reed Amar, Of Son ereignth and Federalism. 96 YALE L.J. 1425, 1504-18 (1987) [hereinafter Amar. Sovereignn.]. Alshl Reed Amar. Using Srate Law to Protect Federal Constitutional Rights: Some Questions and Answers About Converse-1983. 64 U CoLo L. REV. 159 (1993) [hereinafter Amar, Converse-1983] See generally Paul M Bator. The State Courts and Federal Constitutional Litigation, 22 WM. \& M. L. REV. 605, 627 (1981) (urging that state couns remain equal partners with federal courts in enforcing consututional pnnciples) While the focus of this Arucle has been remedies against state-level officials, its suggestion that there is a constututuonal baseline of required remedies against state officials, whether in actions in state or in federal court, might imply a similar baseline as against federal officials.

This conclusion, however, would not necessarily suppon Amar's argument that state causes of detion currently would be a useful avenue for enhancing exisung constitutionil remedies agunst tederal officers See Amar, Converse-1983, supra, at 174. To the contrary. the Supreme Court might well see the line between liability and immunity for federal officers as a federal ussue that would preclude state augmentation of constitutional remedies against federal officers. Bur cf. td. at 174-75 (argumg that converse- 1983 actions would not necessarily have to allow for good faith immunity) State remedies against federal otficers would become significant primarily in the case of congressional allempts to cunall or deny remedies in federal cours. See Har, supra note 93, at 1401; cf. Amar. Converse-1983. supra, at 172-74 (nuting the significance of converse-1983 if Bivens v. Six Unknown Naned Agents of the Federal Bureau of Narcolics, 403 US 388 (1971), were overruled). 
and Section III.C describes how it worked in challenges to illegal taxation. The rate regulation and tax cases, over which federal jurisdiction was virtually eliminated in the New Deal, reinforce the inference that trespass actions against individual officers for certain unconstitutional exactions are constitutionally compelled, whether a cause of action derives from state or federal law.

\section{A. Nondiversity Federal Question Cases: Virginia Coupon Redux}

Federal question cases raising constitutional issues emerged from the same baseline trespass action that the Supreme Court in Poindexter had compelled the state to maintain. Indeed, the Virginia Coupon Cases $^{245}$ provide a glimpse into the common origins of diversity actions raising constitutional issues, compelled remedies in state courts, and federal question constitutional cases. As noted above, ${ }^{246}$ the subject of the Virginia Coupon Cases was the state legislature's repeal of mandamus and trespass actions against revenue officers. The Supreme Court, however, not only reinstated the state court trespass remedy that Virginia had attempted to abrogate, but also allowed a federal court diversity action by an out-of-state party to enjoin collection officials from seizing its property to collect taxes following the tender of coupons. ${ }^{247}$ In addition, the Court reinstated a nondiversity, federal question damages action brought by an in-state taxpayer against the collector that the federal trial court had dismissed. ${ }^{248}$

In the course of its opinion, the Court addressed arguments that the Rules of Decision $\mathrm{Act}^{249}$ and the Conformity Act of $1872^{250}$ required the federal courts to restrict remedies to the refund suit allowed by state law. ${ }^{251}$ The Rules of Decision Act, originally enacted as section 34 of the Judiciary Act of 1789 , provided that " $[t]$ he laws of the several states, except where the constitution, treaties or statutes of the United States shall otherwise require or provide, shall be regarded as rules of decision in trials at common law, in the courts of the United States in cases where they apply."252 The Supreme

245. 114 U.S. 269 (1884).

246. See supra text accompanying notes $214-218$.

247. See Allen v. Baltimore \& O.R.R., 114 U.S. 311 (1884). The Court in Allen seemed to suggest that the case also could have been brought under federal question jurisdiction. See id. at 316.

248. See White v. Greenhow, 114 U.S. 307,308 (1884). The dismissal was on a general demurrer and could have been based on a lack of jurisdiction or on the repeal of the cause of action under Virginia law, the latter being the issue addressed in the main opinion in Poindexter v. Greenlow, 114 U.S. 270 (1884).

249. Ch. $20, \S 34,1$ Stat. 73,92 (1789).

250. Ch. $255, \S 5,17$ Stat. $196,197$.

251. See Poindexter, 114 U.S. at 301-02. The discussion in Poindexter, the main opinion in the Virginia Coupon Cases, reviewed the denial of a tort action in state court. The Court's discussion in Poindexter of the Conformity Act and Rules of Decision Act, however, secmed directed to White v. Greenhow, 114 U.S. 307 (1884), the damages action that originated in federal coun, given that the Acts would be more directly applicable to cases tried in federal courts.

252. $\S 34,1$ Stat. at 93 (codified as amended at 28 U.S.C. $\$ 1652(1994)$ ). 
Court, however, found that the exception to the Act for instances in which the Constitution "otherwise require[s]" allowed federal courts to disregard the state restriction on trespass-type suits. ${ }^{253}$ In addition, the Conformity Act's requirement of dynamic adherence to state practice and procedure required only conformity "as near as may be,"2s, thereby implying a like exception. ${ }^{255}$ Both Acts therefore allowed the federal courts to deviate from state law, particularly because, as the Court stated, a law forbidding all redress in actions at law for injuries to propenty would violate due process. ${ }^{36} \mathrm{An}$ assumption that tort remedies against the wrongdoing official were necessarily available could therefore be said to be an animating source of the new federal question action, as well as of the required state cour action and the federal diversity action addressing similar tortious behavior undertaken in violation of the Contracts Clause.

As discussed in Part I, traditional federal courts scholarship has tended to see the source of the cause of action against state officers in federal courts as initially grounded in state law with federal ingredients added in-a cause of action, however, that gradually came to be perceived as federal rather than state. ${ }^{257}$ Modern scholars, on the other hand, may be so accustomed to seeing actions for the vindication of federal rights as taking their source in federal law that they might characterize such actions as federal question cases-cases that not only were recognized in federal courts, but that also were forced onto the state courts, in much the same way that state courts might be compelled to entertain congressionally created causes of action. ${ }^{258}$ Neither description, however, accurately captures the relation of state and federal courts at the time, nor does it fully describe their relationship now. ${ }^{35 y}$ Courts of both the state and federal governments were enforcing causes of action that did not have their source in the positive law of the other; yet in both cases, the actions' continued existence was in important respects constitutionally compelled.

\section{B. Rate Regulation and the Rise of Due Process}

As shown by the Virginia Coupon Cases, early nondiversity federal question cases enforcing constitutional rights did not differ appreciably from

253. See Poindexter, 114 U.S. at 303

254. $\$ 5,17$ Stat. at 197.

255. See 114 U.S. at 303; see also supra note 123 (providing the text of the Conlurmity Act)

256. See Poindexter, 114 U.S. at 303

257. Har traces federal question equity actions to state-law-based trespass zetions that gradually lost their state law roots. See Hart, supra note 17, at 524

258. Cf. Fallon, supra note 17, at 355 (sceking to charictenze possibly compulsury remedies ugainst

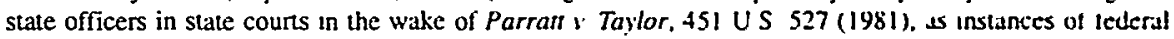
abstention). The abstention characterization may imply a federal law source of such actions

259. See infra notes 368-384 and accompanying text, of White v Greenhow, 114 US 307. 308 (1884) (indicating that all questions on the ments in the federal trespass action had been disposed ot in the state law trespass case). 
diversity trespass actions or parallel equity cases that raised similar federal issues. Although diversity continued to be the proven and preferred means of raising federal questions, ${ }^{260}$ parties gradually began to use federal question jurisdiction, ${ }^{261}$ typically because they had to when the parties happened not to be diverse. ${ }^{262}$ Thus, the 1875 Act caused no abrupt change in the original jurisdiction of the lower federal courts; diversity provided the primary jurisdictional basis for raising federal constitutional issues both before and after the Act. ${ }^{263}$ An example of the emerging rise of federal question jurisdiction was in suits to enjoin unreasonable railroad rates as violative of the Due Process Clause.

\section{The Ambiguous Source of Law for "Reasonableness"}

The results in railroad rate cases reinforce those in the Virginia Coupon litigation. They show that state courts were required to maintain certain trespass-style proceedings and that federal courts would entertain similar actions raising the same issues. The federal courts, moreover, would entertain these actions and consider those issues whether the action was brought under diversity or federal question jurisdiction. For example, in the Milwaukee Road

260. See, e.g., Henderson v. Mayor of New York, 92 U.S. 259 (1875) (enjoining a passenger tax as a violation of congressional powers over foreign commerce, in a suit brought by British stcamship owners against the Mayor of New York and the city Commissioners of Emigration). Diversity was also preferable if uncertainty existed as to whether the case presented a federal question, since the plaintiff would still be able to obtain a federal court determination of the nonfederal issue. For example, in Transportation Co. $v$. Parkersburg, 107 U.S. 691, 706-07 (1882), the Court found that there was no federal jurisdiction because an allegation of unreasonable wharfage (as opposed to tonnage) charges did not present a Commerce Clause issue. The Court noted, however, that if there had been jurisdiction, the federal court would apply state law as to the wharfage charges, and it would not be supposed that the law authorized exorbitant charges. See id.

261. Both had amount-in-controversy requirements. See HART \& WECHSLER, supra note 1, at 349.

262. For example, in Scott v. Donald, 165 U.S. 58 (1897) (damages action), 165 U.S. 107 (1897) (equity action), the Court entertained trespass-type actions brought under federal question jurisdiction against state officials who had seized the plaintiff's propeny under a state statute that the plaintifl claimed violated the Indian Commerce Clause.

263. Although the dockets of the federal courts increased following the 1875 Act, see FRANKFURTER \& LANDIS, supra note 3, at 77-78, it is not clear that original federal question jurisdiction contributed much to the augmentation. Subsequent congressional discussion of the need to decrease federal dockets focused on diversity jurisdiction, see Collins, supra note 25 , at 739-40, 744-45, which was also expanded by the $1875 \mathrm{Act}$, see id. at 723-24, $728 \mathrm{n} .60$. The main significance of the 1875 Act's provision for federal question jurisdiction may have been the Court's interpretation of the federal question removal provision as allowing removal of state cour enforcement actions raising federal defenses, an interpretation that enabled corporations to obtain a federal forum in which to resist state economic regulation. See id. at 724 29. Indeed, federally chartered railroads could remove actions brought against them in state courts, based on their federal charters, even where no genuine federal issue was involved. See id. at 747. The decision in Tennessee v. Union \& Planters' Bank, 152 U.S. 454 (1894), ended federal delense removal and may have focused attention upon the use of original federal question jurisdiction, see, e.g., Smyth v. Amcs, 169 U.S. 466 (1898), particularly in cases that anticipated state enforcement suits. See, e.g., Ex parte Young, 209 U.S. 123 (1908); Coliins, supra note 28, at 1515 (suggesting that constitutional litigants worricd about whether the federal element was part of a complaint only after federal defense removal became unavailable). 
Case, ${ }^{264}$ the Court had required, as a matter of the Fourteenth Amendment's Due Process Clause, that state courts entertain challenges to the reasonableness of rates. ${ }^{265}$ The Court's requirement of a judicial assessment of reasonableness resembled the Court's compelling the state to maintain a trespass action in the Virginia Coupon Cases; the Court saw an unreasonable rate as an unjustified taking or trespass for which the states were required to provide judicial redress. ${ }^{266}$

In the early rate cases brought in federal courts in which the reasonableness of rates was at issue, however, it was not entirely clear whether reasonableness was a federal issue sufficient to give federal question jurisdiction if the parties were not diverse. In Milwaukee Road, a case arising from state court, the Due Process Clause arguably was implicated only insofar as the state was required to provide a judicial assessment of reasonableness, whose substance was perhaps not a federal issue. Of course, so long as the parties in federal court were diverse, the Court was not obliged definitively to resolve whether reasonableness was a nonfederal concept (but one which the federal courts might interpret pursuant to general law principles), or whether reasonableness received its substantive content from the Due Process Clause. Even if reasonableness were not considered a federal issue, but merely a matter of general law, federal diversity courts in this era would still be free to ignore state decisions as to what was reasonable.

In fact, the Court did not fully resolve whether the reasonableness of rates presented a distinctly federal issue even in Reagan $v$. Farmers' Loun \& Trust

264. Chicago, M. \& St. P. Ry. v. Minnesota, 134 U S 418 (1890)

265. See id. The case came to the Supreme Cour on direct revew of a judicial provecding to enlurte administrative rates in state courts by a mandamus action aganst the ralload See ad at 435 The Court. however, appeared to require a judicial investigation of reasonibleness as pan of the process by which the state could impose rates. See id. at 457-58; see also id. at $459-60$ (Miller, J . concurning) (agreetng that there is a judicial remedy for rates so unreasonable as practically to destroy the value of a common carrier. but urging that the carrier must submit to the rates unul judicial appead). Reagan $\times$ Farmers Loan $\&$ Trust Co., 154 U.S. 362, 396-97 (1894) (rejecting an argument that the issue of reasunableness of rales was beyond the examination of the court in a diversity equity actuon)

266. The Cour explained:

If the company is deprived of the power of charging reasonable rales for the use of its propeny. and such depnvation takes place in the absence of an investigution by judicial muschinery, II is deprived of the lawful use of its property, and thus, in substance and eflect. of the property itself, without due process of law .... and in so far as it is thus depnved, while uther persuns are permitted to receive reasonable profits upon their invested capits. the company is depnved of the equal protection of the laws.

Chicago, M. \& St. P. Ry., 134 U.S. at 458; see also Reagan. 154 U S 4391 (using trespuss anslogies in holding that an action to enjoin unreasonable rates was not barred by the Eleventh Amendment), Sicphen A. Siegel, Understanding the Lochner Era: Lessons from the Controv ersv os er Ratroud and Uulan Rate Regulation, 70 VA. L. REV. 187, 213 (1984) (staung that the requirement of judicial determination ot reasonableness of rates, with its protection of the value of propeny rather than merely utle and possession. grew out of new economic conditions and the traditional constilutionsl concerns for independence that underlay protection of propery). In addiuon to trespass remedies. shippers' common law detions challenging camiers' rates as unreasonable may also have been a source for the sctions assessing reasonableness at the instance of the regulated pary See Reagan. 154 U S at 397 (reasoning that the reasonableness of rates was a matter for the judiclary based on traditional remedies aganst canners for unreasonable rates); see also Siegel, supra, at 197 (discussing such «ctions) 
$\mathrm{Co}^{267}$-a case sometimes viewed as an early manifestation of substantive or economic due process. ${ }^{268}$ In Reagan, an out-of-state trustee on railroad bonds sued in federal court to enjoin what it claimed were unreasonable rates. ${ }^{269}$ Clearly, the state could not foreclose judicial consideration of reasonableness in its own courts ${ }^{270}$ - that much had been apparent after Milwaukee Road. Nor, said the Reagan Court, could the state restrict the judicial consideration of reasonableness to its own courts by providing that suits had to be brought against the rate-setting agency in courts in a particular county. ${ }^{271}$ The Supreme Court indicated that actions for trespassory harms would be available against state officers, and that, as to such actions, "[a] state cannot tie up a citizen of another State, having property rights within its territory invaded by unauthorized acts of its own officers, to suits for redress in its own courts."272 The right of the out-of-state bond trustee to bring a diversity action to protect property from trespassory impositions was thus itself a federally protected right whether or not reasonableness was considered a federal issue. The decision in Reagan illustrated that those subject to ratemaking could accomplish in a diversity action the substantial equivalent of federal question treatment.

\section{The Emerging Federalization of General Law Norms}

It was therefore only a short but perceptible intellectual step from diversity's protection of property of out-of-staters to federal question's protection of property of in-staters through the Due Process Clause. ${ }^{273}$ In Smyth v. Ames, ${ }^{274}$ a turn of the century diversity case brought by corporate shareholders against state officers, the state had attempted to restrict challenges to the reasonableness of railroad rates to state court lawsuits between the company and the state. ${ }^{275}$ The U.S. Supreme Court held that federal

267. 154 U.S. 362 (1894). The Cour held that the federal courts had power to revicw the reasonableness of rates, but seemed reluctant to state clearly that an unreasonable rate was a due process violation. See id. at 397.

268. See, e.g., Siegel, supra note 266 , at $189 \mathrm{n} .9$ (characterizing Reagan as the Court's first substantive due process ruling).

269. See 154 U.S. at 366-67.

270. See id. at 396-97.

271. See id. at 391-92. Had reasonableness remained a nonfederal concept, the results would have been similar to those in municipal bond cases. There the enforceability of the contracts in federal courts, although bordering on the Contracts Clause, was a matter of general, not federal, law.

272. Id. at 391; cf. Alfred Hill, The Political Dimension of Constitutional Interpretation, $63 \mathrm{~S}$. CAL. L. REV. 1237, 1315-22 (1990) (discussing early substantive due process decisions); Siegel, supra note 266, at 189 \& $\mathrm{n} .9$ (noting that railroad and utility regulation cases like Reagan were the cutting edge of substantive due process).

273. See HOVENKAMP, supra note 10, at 19 (tying the rise of substantive due process and the recognition of corporations as persons under the Fourteenth Amendment to the earlier movement to conceptualize the corporation as a person for diversity purposes).

274. 169 U.S. 466 (1898).

275. See id. at $469-70$ (describing the parties to the three cases); id. at 474 (citing a state statutc providing that "[a]ll such actions shall be brought before the [state] Supreme Court in the name of the 
jurisdiction was proper and bolstered that holding by explicitly federalizing the content of "reasonableness." The Cour indicated that suits to enjoin unreasonable rates might be brought as federal question cases, a suggestion that shareholders challenging railroad rates followed nearly a decade later in Ex parte Young. ${ }^{276}$ The bedrock rights as against trespassory harms thus led to the requirement of state judicial assessments of reasonableness, to federal court diversity cases addressing reasonableness, and finally, to federal question actions addressing the very same issue. In the process, reasonableness shifted from a "general law" concept which might not have merited federal question status to an explicitly federal one whose substance was defined by the Due Process Clause.

Federal suits contesting confiscatory rates such as Smyth $v$. Ames, while rooted in the concept of trespass, ${ }^{277}$ nevertheless differed from traditional trespass actions in important respects. In the common law action, the constitutional question arose in response to the official's defense of justification to the plaintiff's claim of trespass. In the case of a seizure or threatened seizure to collect a tax under an unconstitutional statute, the trespass was palpable. It clearly had occurred or would imminently occur; the issue that arose by defense and reply was whether the trespass was justified. The concept of the confiscatory rate, however, collapsed the elements of trespass and justification. The trespass in such cases occurred by way of the unreasonable rate's eating away at invested capital or leading ultimately to the seizure of the shareholders' title by foreclosure; ${ }^{278}$ if the rates were reasonable, however, there was no trespass.

This compression of tort claims and defenses facilitated pleading the federal issue of unreasonableness in the plaintiff's case-in-chief. That, in turn, ensured a federal forum, consistent with the well-pleaded complaint rule that restricted lower federal court jurisdiction in federal question cases. ${ }^{279}$ Pleading of the federal issue as part of plaintiff's own case had arguably

railroad company or companies bringing the same, and against the state of Nebrasks"), see also id a 516 17 (quoting from Reagan to the effect that the state was unable to resind out-ot-stalers with in-slate property to its own courts).

276. 209 U.S. 123, 144 (1908) ("The sufficiency of rates with relerence to the Federal Constitution is a judicial question, and one over which Federal couns have junsdiction by reason of its Federal nature " (citations omitted)).

277. See Siegel, supra note 266, at 221, 227 (describing the view that value diminution could amount to a taking). According to views described by Professor Siegel, a government-1mpused rate. Il low enuugh. resembled a taking of title or physical seizure, since scizure of the shareholder's tulle by bunkruptcy or foreclosure would follow. See id. at 224-26. Sicgel also states that the concept of using the present value of a company's assets as the rate base in Sinyth denved from andlogies to condemnation proxedures where present value would be awarded. See id. al 226-28; see also John N Drobak. From Tumpike to Nuclear Power: The Constitutional Limits on Utility Rate Regulation, 65 B U L REV 65. 78 (1985) (stuting thut in Smyth the "fair return on fair value" principle. as opposed to book value, was based on Takings Cluuse and eminent domain analogies).

278. See Reagan v. Farmers' Loan \& Trust Co, 154 U.S 362, $391,398-99$ (1844) (apparently characterizing the action to enjoin rates as an action for trespass and as a remedy for a laking)

279. See, e.g., Louisville \& N.R.R. v Mottley, 211 U S 149 (1908) 
already occurred in more traditional trespass actions that raised constitutional issues, such as in the Virginia Coupon Cases. ${ }^{280}$ But subsequent to Ex parte Young, a rate case, the concept of the general law trespass began to fade, to be replaced with a cause of action that was perceived to be constitutionally sourced. The deemphasis on allegations of a common law trespass led, in turn, to the gradual replacement of such allegations with requirements of allegations of the plaintiff's standing and the defendant's breach of a constitutional duty.

The coupon and rate regulation cases together show that federal question constitutional actions developed from a number of sources, of which state law seems to have played only a marginal role. Instead, federal question actions grew more directly from the independence of federal courts, sitting in diversity, in supplying rights and remedies in cases involving federal issues. It is possible to identify the ancestor of modern implied constitutional rights of action as state law causes of action only by anachronistically reading back into the past a post-Erie analysis, which assumes that state law is the modern legitimate descendant of general common law. But because the general common law applied in the federal courts in federal question diversity cases often departed from state law to accommodate federal rights, it is probably more accurate to see the source of the federal actions as a kind of federalized general common law. ${ }^{281}$ This federalized general common law was combined with an embedded sense of constitutional compulsion to trespass actions for deliberate invasions of property by state and local officers, whether the action was one in state or federal court, to form the basis of modern constitutional implied rights of action. ${ }^{282}$

\section{Compelled Remedies for Illegal State Taxation}

The presumptive existence of remedies for governmental trespasses that underlay these three remedial tracks (nondiversity federal question cases, diversity actions raising constitutional questions, and compelled remedies in

280. See White v. Greenhow, 114 U.S. 307 (1884). In addition, in Scott v. Donald, 165 U.S. 58 (1897), the Court had allowed federal question damages and injunction claims where state constables had seized and threatened to seize property under a state law that violated the Commerce Clause. Scott was decided subsequent to the advent of the well-pleaded complaint rule in Metcalf $v$. Waterfown, 128 U.S. 586 (1888). See also Tennessee v. Union \& Planters' Bank, 152 U.S. 454 (1894) (applying the well-pleaded complaint rule to a removed action).

281. See Hill, supra note 113, at 1132-34 (questioning whether the source of causes of action for constitutional remedies should be seen as state law); $c f$. Fletcher, supra note 42, at 1514, 1527 (concluding that section 34 of the Judiciary Act of 1789 was declaratory of a larger lex loci principle under which federal courts would apply state law only in areas of local concern); Hill, supra note 152, at 1013 (stating that in applying the gencral law, the federal courts in theory had no thought of overriding state law in the name of a federal common law, as they understood they were acting in areas where only the states had substantive power); Seth F. Kreimer, The Source of Law in Civil Rights Actions: Some Old Light on Section 1988, 133 U. PA. L. REv. 601 (1985) (concluding that Congress in 42 U.S.C. $\$ 1988$ directed federal courts to follow the general common law, not state law, to fill gaps in the 1871 Civil Rights Act).

282. See Hill, supra note 113 , at $1132-34$. 
state courts) was illustrated in actions for remedies for illegal taxation prior to the Tax Injunction Act of $1937 .{ }^{283}$ This aspect of the history of federal courts remains relatively unexplored for the simple reason that for the last sixty years constitutional challenges to taxes have been subject to the Act. 28 : But the principles of constitutionally compelled remedies arising from decisional law prior to that enactment have contemporary relevance.

First, this section will discuss the continuing provision of remedies for federal constitutional violations through federal court diversity and federal question actions, as well as through compelled state court remedies. Similar to pre-1875 practice, federal court remedies in both law and equity for unconstitutional taxes were often brought in diversity. Also similar to pre-1875 practice, federal remedies in both law and equity apparently were not controlled by restrictions on remedies available in state cour.

This section will then explore two additional aspects of state tax remedies. It will show that in a little-noted opinion, ${ }^{285}$ Justice Holmes helped to suspend the availability of federal court remedies at law in both diversity and federal question cases that deviated from state remedies. The decision, and the hostility to a common law baseline of required constitutional remedies reflected therein, helps to explain the disappearance of constitutional damages actions, which, in turn, required the Court to reinvent them in Monroe $e^{2 s o}$ and Bivens. ${ }^{287}$

In addition, this section will discuss the federal courts' provision of equitable remedies for taxes that were illegal under state law, even in the teeth of state restrictions on remedial rights. The availability of federal court remedies for such illegal taxes suggests that, even beyond compulsory remedies for federal constitutional violations, remedies for some state law violations may be constitutionally required.

\section{Federal Injunctions Against Unconstitutional Taxes}

Consistent with earlier practice, federal equity courts late in the last century and early in this one did not feel constrained to follow state law restrictions on remedial rights that might have barred similar actions in state courts. Many states had, by statute, restricted remedies for illegal taxation 10 post-payment refund suits, and barred prospective tax injunctions. While the

283. 28 U.S.C. $\$ 1341$ (1994) ("The district courts shall not enjoin. suspend or restratn the assessment, levy or collection of any tax under State law where a plain, specdy and efficient remedy may be had in the courts of such State.").

284. Cf. National Private Truck Council v. Oklahoma Tax Comm'n. 515 U S 582 (1995) (interptetıng $\$ 1983$ as not authorizing damages actions in state tax cases), id at 2354-55 (noting that tederal courts had been consistently respectful of state coun tax remedies since 1871)

285. See Burrill v. Locomobile Co. 258 U.S. 34 (1922)

286. Monroe v. Pape, 365 U.S. 167 (1961)

287. Bivens v. Six Unknown Named Agents of Fed Bureau of Narcoucs. 403 U S 388 (197!) 
Supreme Court on direct review of state courts did not force state courts themselves to issue tax injunctions contrary to state statutory limitations, lower federal courts granted such injunctions without regard to state prohibitions. ${ }^{288}$ Nor did federal courts heed state attempts to restrict taxpayer actions to suits against the state in its own name, which would have precluded federal jurisdiction because of Eleventh Amendment and sovereign immunity concerns. Rather, in federal courts, injunctive actions could be brought against individual collection officers based on the background theory that a forcible collection of an illegal tax was an unjustified trespass. ${ }^{289}$ And such injunction actions could be brought in federal court, state law to the contrary notwithstanding.

Prior to the Tax Injunction Act, it was not state statutory prohibitions, but rather federal equitable requirements, that posed the main hurdles to obtaining tax injunctions in federal courts. Parties seeking such injunctions had to allege more than the illegality or unconstitutionality of the challenged tax; litigants also had to show the inadequacy of remedies at law. Such a showing might include allegations that the state's post-payment recovery would necessitate a multiplicity of actions, or evidence that there were systemic assessment problems. $^{290}$

In seeking injunctions against taxes alleged to violate the Constitution, federal court litigants continued to rely heavily on diversity jurisdiction well into this century, long after the general federal question statute had become available. ${ }^{291}$ Thus, as was true for other constitutional claims, the 1875

288. See In re Tyler, 149 U.S. 164, 189 (1893) (stating that state limits on relief in refund actions had no restrictive effect on federal courts).

289. See, e.g., City Bank Farmers Trust Co. v. Schnader, 291 U.S. 24, 29 (1934) (holding that a federal equitable remedy against the collector was appropriate where the remedy in state court was against the state only); see also Chicago, B. \& Q.R.R. v. Osborne, 265 U.S. 14, 16 (1924) (reiterating that federal equity was available when a remedy at law was available only in state court).

290. See, e.g., State R.R. Tax Cases, 92 U.S. 575, 613 (1875) (noting in an equity suit raising issues of illegality of a tax under state law that neither the mere illegality of a tax nor its injustice or irregularity alone gave a right to an injunction). In discussing why the particular case did not come within any of the grounds for a tax injunction, the Cour stated:

There is no fraud proved, if alleged. There is no violation of the [state] constitution, either in the statute or in its administration, by the board of equalization. No property is taxed that is not legally liable to taxation, nor is the rule of uniformity prescribed by the [state] constitution violated. If there is an excessive estimate of the value of the franchise or capital stock, or both, it is by an error of judgment in the officers to whose judgment the law confided that matter; and it does not lie with the court to substitute its own judgment for that of the tribunal expressly created for that purpose.

Id. at 615-16; see also Shelton v. Platt, 139 U.S. 591, 594-96 (1891) (finding equity jurisdiction inappropriate in an action to enjoin a tax because requirements of harms beyond illegality of the tax had not been met); $c f$. Union Pac. Ry. v. Cheyenne, 113 U.S. 516, 525 (1885) (holding that equitable relief was appropriate to enjoin violation of a territorial law providing for unified rather than local assessment when the railroad ran through several counties).

291. See, e.g., City Bank Farmers Trust Co., 291 U.S. 24 (reinstating a diversity action filed by a New York executor against state officials to enjoin on Fourteenth Amendment grounds the collection of a tux on paintings on loan to an institution in Pennsylvania at the time of the decedent's death); Fargo v. Hart, 193 U.S. 490 (1904) (enjoining certification of an assessment in a diversity action where a tax unconstitutionally reached property in the state of incorporation); cf. Singer Sewing Mach. Co. v. Benedict, 229 U.S. 481, 486 (1913) (disallowing a suit in equity challenging taxes on federal grounds by an out-of- 
general federal question statute did not work a dramatic change in the original jurisdiction of federal courts. Of course, federal question jurisdiction could still be alleged alone where diversity was impossible to allege. ${ }^{292}$

\section{Federal Court Damages Actions to Remedy Unconstitutional Taxes}

In the nineteenth century, federal court damages remedies for taxes alleged to violate the Constitution, like injunctive remedies, did not conform to state court limitations on such actions. Thus in Deshler v. Dodge, ${ }^{293}$ a diversity case raising a Contracts Clause challenge to taxation before the enactment of the 1875 general federal question statute, the Court ignored a state limitation that disallowed detinue actions where property was seized in payment of a tax. Similarly, in the Virginia Coupon Cases, ${ }^{294}$ the Court recognized a federal question trespass action against a collector who seized property under an unconstitutional statute, despite the state's attempt to limit taxpayers to a procedurally complicated refund action.

Litigants early in this century continued, with Supreme Cour approval, to pursue actions at law in federal courts against collectors who had collected unconstitutional taxes. ${ }^{295}$ As was true in equity, diversity remained the preferred jurisdictional basis for tax challenges, ${ }^{296}$ despite the Virginia

state corporation against the collector of city and county taxes because of the avalability of an adequale remedy at law either in state court or in federal coun, if jurisdiction existed). Nastonal banks and federally chartered railroads could obtain federal jurisdiction until 1882 and 1915, respectively, without regard to diversity. See McGovney, supra note 46, at 1123 (discussing nalıonal banks); supra noic 106 (discussing federally chanered railroads).

292. See Lincoln Gas \& Elec. Light Co. v. City of Lincoln, 250 U.S. 256, 264 (1919) (repontung a suit by an in-state corporation against a city and its officers challenging rates and an occupation tax): Greene v. Louisville \& I.R.R., 244 U.S. 499, 513 (1917) (sustaining an injuncuon on stalc law grounds in a federal question case); cf. Siler v. Louisville \& N.R.R., 213 U.S. 175. 194 (1909) (granting an injunction against a rate order on state law grounds in a case broughi under federal question jurisdiction). The Coun upheld federal question jurisdiction if there was a substantial allegation that the taxing statute or assessment system violated federal law. See Risty v. Chicago, R.I. \& Pac. Ry.. 270 U.S. 378. 381.387 (1926) (noung in consolidated cases granting an injunction on state law grounds at the instince of ralroads that in all cases, except one, diversity existed, and that the federal question as to assessments was substanial enough to confer jurisdiction).

293. 57 U.S. (16 How.) 622 (1853), discussed supra notes 69-72, 159.164 and accompanying lext.

294. 114 U.S. 269 (1884), discussed supra notes 214-229 and accompanying text.

295. See Atchison, T. \& S.F. Ry, v. O'Connor, 223 U.S. 280, 286-87 (1912) (finding that a payment by a Kansas corporation to a Colorado collector had been under duress and that a refund action was therefore available); $c f$. Matthews v. Rodgers, 284 U.S. 521, 525.26 (1932) (finding. with respect to a claim to enjoin a tax on Commerce Clause grounds, that an adequate remaly at law existed that could be brought in state coun, or federal cour, assuming jurisdiction); Pickard v. Puliman S. Car Co. 117 U.S 34 (1886) (affirming a Kentucky corporation's right to a refund of a payment made to the Tennessee comptroller).

296. See, e.g., Allen v. Pullman's Palace Car Co., 191 U.S. 171 (1903) (granting relief in what was apparently a diversity action against a state official to recover laxes pand under protest. where the taxes violated the Commerce Clause); Pickard, 117 U.S. 34; cf. Gaar. Scoll \& Co. v. Shannon, 223 U S. 468 (1912) (considering what was apparenty a diversity suit by an Indiana corporation against the Texas Secretary of State to recover a tax paid, but not reaching the constitutional issue because of the voluntary payment). Litigants may have alleged both diversity and federal question jurisdicuon in these cases. So long as diversity was present, the Supreme Court would not have needed to address whether federal question jurisdiction was proper. 
Coupon Court's having given the green light to federal question damages actions in such cases. ${ }^{297}$ For a time, such actions at law continued to manifest the same independence of state positive law as had Deshler and the Virginia Coupon Cases. For example, in Atchison, Topeka \& Santa Fe Railway v. $O^{\prime}$ Connor, ${ }^{298}$ the Supreme Court upheld a federal court assumpsit action brought by an out-of-state corporation against a state collector to recover a tax that violated the Commerce Clause. ${ }^{299}$ The state apparently argued that assumpsit was not a proper remedy under state law. ${ }^{300}$ The part of Justice Holmes's opinion for the Court approving the federal court assumpsit remedy made no reference to the state's law, relying instead on the general principle that "[i]t is reasonable that a man who denies the legality of a tax should have a clear and certain remedy."301

The common law assumpsit action that the Court entertained in $O^{\prime}$ Connor was for payment made under protest or duress. ${ }^{302}$ Such an action may at first glance appear to be somewhat beyond the baseline trespass remedy that the federal courts supplied against state officials. Such actions, however, were close relatives to the trespass actions, ${ }^{303}$ and similarly could be brought

297. See White v. Greenhow, 114 U.S. 307 (1884) (upholding federal question jurisdiction for a claim in which the plaintiff sought damages for property seized to satisfy a tax).

298. 223 U.S. 280 (1912).

299. See id. at 285.

300. The state argued that the railroad should have awaited an enforcement action or sought an injunction. See id. at 284 (argument of counsel). The railroad did not rely on state cases in arguing for the availability of an assumpsit. See id. at 282 (argument of plaintiff). Justice Holmes's majority opinion discussed the propriety of an assumpsit for payments under duress without reference to remedies in the statc courts. See id. at 285-87. The opinion finally adverted to state law in the final paragraph, when it addressed whether the Secretary of State was the proper party defendant. The Court noted:

Moreover it would seem that the statute contemplated the course taken by the plaintiff and provided against any difficulty in which the Secretary of State otherwise might find himself in case of a disputed tax. For it provides by $\S 6$ that "if it shall be determined in any action at law or in equity that any corporation has erroneously paid said tax to the Secretary of State," upon the filing of a certified copy of the judgment the auditor may draw a warrant for the refunding of the tax and the state treasurer may pay it.

Id. at 287. This argument might also have inferentially supported the argument for the availability of the assumpsit, by implying that this remedy was available under state law.

301. Id. at 285 .

302. Cf., e.g., Oliver P. Field, The Recovery of Illegal and Unconstitutional Taxes, 45 HARV. L. RBV. 501,511 (1932) (declaring that "It]he generally stated rule in the absence of statute is that illegally collected taxes may not be recovered unless they are paid under compulsion and under protest"); Philip M. Tatarowicz, Right to a Refund for Unconstitutionally Discriminatory State Taxes and Other Controversial State Tax Issues Under the Commerce Clause, 41 TAX LAW. 103, 120-21 (1987) (discussing the common law remedy of payment under protest). For examples of assumpsit actions against federal collectors, sec Maxwell y. Griswold, 51 U.S. (10 How.) 242, 256 (1850), an action against a collector for the return of duties paid under protest; and Ann Woolhandler, Patterns of Official Immunity and Accountability, 37 CASB W. RES. L. REV. 396, 414 n.87 (1987), which gathers additional authorities.

303. See O'Connor, 223 U.S. at $285-86$ (stating that, with regard to cases in which the state need not bring an enforcement action when a citizen refuses to pay taxes, "but when, as is common, the State has a summary remedy, such as distress, and the party indicates by protest that he is yielding to what he cannot prevent, courts sometimes perhaps have been a little too slow to recognize the implied duress under which payment is made"); Robertson v. Frank Bros., 132 U.S. 17, 22 (1889) (noting, in an action to recover an allegedly illegal duty paid to a federal collector under protest, that actual violence or physical duress wis not required); $c f$. Shelton v. Platt, 139 U.S. 591,600 (1891) (indicating that proceedings to enforce the tax 
against individual officers ${ }^{304}$ without a sovereign immunity bar. ${ }^{305}$ The payment under protest was conceptualized as a substitute for taxpayer nonpayment and as the inevitable forcible seizure of the taxpayer's property by the government officer. Because a seizure would have given rise to a trespass action, protest and payment stood in for taxpayer nonpayment and official seizure.

\section{Required Tax Remedies in State Courts}

The equity actions and trespass/assumpsit actions for damages that the federal courts entertained without regard to the particulars of state law causes of action (and without regard to the basis of jurisdiction) were paralleled by the Supreme Court's requirement that the state courts also make available trespass-type remedies for taxes alleged to violate federal law. In Ward $v$. Board of County Commissioners, ${ }^{306}$ for example, Native American taxpayers sought to recover taxes paid, after threats of tax sales, on land for which the taxpayers claimed a federal exemption. ${ }^{307}$ The Supreme Cour forced the state to entertain the assumpsit action despite the state cour's holding that the tax had not been coercively collected and that there was no statutory cause of action to recover it under state law. ${ }^{308}$ The narrow holding of Ward was that the Court could review the state court's decision as to the issue of "coercion" to ensure that federal rights were not lost. But the Court's reasoning in Ward echoed that in Poindexter $^{309}$ by indicating that the Due Process Clause itself might require trespass-type remedies for the state's coercive exactions. As the Court put it, "To say that the county could collect these unlawful taxes by coercive means and not incur any obligation to pay them back is nothing shor of saying that it could take or appropriate the property of these Indian allottees arbitrarily and without due process of law." ${ }^{310}$

by distress and sale merely constitute an ordinary trespass): Mechanics' \& Traders' Bank v Debolt. 59 U S (18 How.) 380,382 (1855) (indicating that since the parties stupulatod that the treasurer "did foretbly, and against the consent and protest of the plaintiff, take from the plantuff the sand tax." only the constitutionality of the tax was at issue).

304. See, e.g., Jefferson Branch Bank v. Skelly, 66 U.S. (1 Black) 436 (1861) (reversing the state court's holding that there was no Contracts Clause violation in a trespass suit agaunst a collection officer)

305. See $0^{\prime}$ Connor, 223 U.S. at 287.

306. 253 U.S. 17 (1920).

307. See id. at 21-22.

308. The state court had concluded that the taxes were voluntarly pand and that they could not be recovered because there was no statutory provision for such recovery. See id The U S Supreme Court found that the taxes were coercively collecied and that therefore no statutory authonty was necessary See id. at 24 . One could attribute the holding to the inadequacy of state law grounds for finding a noncocreive collection, but the case nevertheless seems to reflect an ussumption that the equivalent of the trespass or assumpsit remedy had to be available. Cf. General Onl Co. v. Cratn. 209 U.S. 211 (1908) (enteruanung direct review on the merits of a case to enjoin a state officer, despite the state court's finding that the action was barred by sovereign immunity).

309. Poindexter v. Greenhow, 114 U.S. 270 (1884); see supra text accompanying notes 225-227

310. Ward, 253 U.S. at 24. 
The Court's record in the tax cases indicates that the baseline requirement of trespass-style remedies in federal courts-whether grounded in diversity or federal question jurisdiction - and in state courts as well, continued well into this century. But two additional features regarding the availability of judicial remedies for illegal taxation during this era are important insofar as they bear on the modern debate over constitutionally compelled remedies. First, during this period, the Court began to curb the federal courts' ability in both diversity and federal question cases to provide damages remedies that deviated from state law, based on an emerging respect for state positive law. This occurrence may help to explain the loss of the tradition of federal courts' supplying constitutional damages actions. Second, the availability during this era of federal court remedies for taxes that were illegal only as a matter of state law suggests that even those remedies may have been constitutionally compelled in some respect. The possibility is significant, insofar as it may shed light on the extent to which remedies may be constitutionally compelled not only for violations of specific rights under the Federal Constitution, but for violations of state law as well.

\section{State Law Limits on "Legal" Relief in Federal Court}

As discussed above, ${ }^{311}$ federal question actions for damages for trespasses under unconstitutional statutes had appeared contemporaneously with federal question equity actions to enjoin trespasses under unconstitutional statutes. Both the legal and equitable actions remedied trespassory harms that proved unjustified because of the unconstitutionality of the statute under which the officer acted, and both suggested an assumption that trespass actions were required more generally. The actions also reflected the independence of the federal courts in supplying remedial rights in both law and equity, without regard to restrictions that states attempted to impose by limiting actions to particular courts or to particular parties. ${ }^{312}$

Justice Holmes, however, almost single-handedly brought a halt to the federal courts' traditional independence in providing monetary remedies in tax cases. In Burrill v. Locomobile Co. ${ }^{313}$ an out-of-state corporation sued state tax collection officials in federal court to recover a tax paid under protest-a

311. See supra text accompanying notes 247-282.

312. The suit, however, had to be properly pleaded against the individual collection official. Compare Smith v. Reeves, 178 U.S. 436, 437 (1900) (disallowing a suit against the defendant "as Treasurer of the State of California" to recover taxes under a California statute allowing for suits against the treasurer), with Pickard v. Pullman S. Car Co., 117 U.S. 34, 35-36 (1886) (upholding an action by a Kentucky corporation against a Tennessee collector after payment under protest pursuant to a state statute), and Atchison, T. \& S.F. Ry. v. O'Connor, 223 U.S. 280 (1912) (upholding an assumpsit action against a state collector). The Court also held in Reeves that the state could restrict waiver of sovereign immunity to its own courts. See 178 U.S. at 441.

313. 258 U.S. 34 (1922). 
tax that the Supreme Court had previously declared violative of the Commerce Clause. ${ }^{314}$ The Court held, however, that the action-which had been brought both under diversity and federal question jurisdiction ${ }^{315}$ - could not be filed in the lower federal courts. The reason offered was, in effect, that state law did not allow it. The state had provided an adequate statutory refund remedy against itself and had expressly made that remedy the exclusive one. ${ }^{316}$ Because the Eleventh Amendment barred a suit against the state in federal court, the action had to be brought in state court. ${ }^{317}$ Thus, by abolishing the common law remedy against its officers and by providing an exclusive action against itself, a state had effectively eliminated the traditionally available federal forum by its substitution of remedies. From the vantage point of the present, the case seems unremarkable because it is illustrative of how the modern Court goes about resolving the propriety of federal court challenges to taxes in light of the Tax Injunction Act. ${ }^{318}$ But at the time (well prior to the Act), the decision represented a shift in the attitude of federal courts in favor of state control of remedies at law against themselves and their officers.

Of course, allowing states to substitute roughly equivalent remedies in state court for the older common law action was nothing new. ${ }^{319}$ What was new in Burrill was the Supreme Court's holding that the state's elimination of the action at law against the individual officer in its own courts could also eliminate the action at law in federal courts. Burrill's result conflicted with the earlier landmark decision in Smyth $v$. Ames, ${ }^{320}$ a federal question and diversity equity action in which the Court had thwarted state attempts to limit

314. See Locomobile Co. of America v. Massachuselts, 246 U.S. 146 (1918).

315. See Burrill, 258 U.S. al 35 (argument of defendant in error).

316. See $t d$. at 37-38. The plaintiffs apparenty missed the six-month limitalson on Iegal remedies against the state. See id. at 37; see also International Paper Co. v. Burrill. 260 F. 664, 664 (D. Mass. 1919) (stating that the state court suit against the state had been dismissed without prejudice because the company missed the requirement of service within six months after payment).

317. See U.S. ConsT. amend. XI; cf. Smith v. Reeves, 178 U.S. 436. 441 (1900) (holding that stales could limit waivers of sovereign immunity to their own courts): Hans v. Louisiana, 134 U.S. I (1890) (holding that sovereign immunity barred federal question as well as state-citizen diversity suits against states in federal courts).

318. See, e.g., Fair Assessment in Real Estate Ass'n v. McNary, 454 U.S. 100, 115.16 (1981) (holding that comity and federalism prevent federal courts from enteruining damages actions challenging state tax systems under 42 U.S.C. \$ 1983 when state law fumishes an adequate legal remedy).

319. See, e.g., Tennessee v. Sneed, 96 U.S. 69. $73-75$ (1877) (allowing the substutution of a refund remedy for a mandamus remedy).

320. 169 U.S. 466 (1898); see also In re Tyler, 149 U.S. 164 (1893). Tyler was a habeas action in which a county sheriff contested a federal court contempt order against him for levying on propeny in the custody of the federal coun in a receivership action. He argued, inter alia. that the remedy for his collection of illegal taxes was exclusively South Carolina's statutory refund action. See id. at 188. The Supreme Coun disagreed. It noted that the state statute manifestly was designed to limit tax remedies to payment under protest and suit against the county treasurer for a refund, "but all this is nothing to the purpose." $1 d$. all 189. It continued, "The legislature of a State cannot determine the juristiction of the courts of the United States, and the action of such courts in according a remedy denied to the courts of a State does not unvolve a question of power." Id.; see also Davenpon v. County of Dodgc, IOS U.S. 237. 242 (1881) (substituting a suit on the contract in federal cour, with mandamus as a post-judgment remedy, for the state court's original mandamus action). 
judicial review of rate regulation to an action against the state in state court. In Burrill, by contrast, the Court accepted previously rejected arguments that the sovereign creating the action could limit it in such a way as to foreclose the federal court action-at least for actions at law against the state itself. According to Holmes, the laws of the state controlled under the Rules of Decision Act, ${ }^{321}$ even as to the remedy for a federal constitutional violation, until Congress provided otherwise. ${ }^{322}$

Such a reading of the Rules of Decision Act, and respect for state positive law, manifested Justice Holmes's crusade against Swift v. Tyson ${ }^{323}$ and his commitment to legal positivism. In the past, the Court had implicitly read the Rules of Decision Act's exception to the application of state law "where the constitution, treaties or statutes of the United States shall otherwise require or provide" as requiring the federal courts to ignore state statutes that would have restricted jurisdiction to suits brought in state courts, even if the state remedies did not appear to be otherwise constitutionally defective. ${ }^{324}$ Burrill therefore represented a significant curtailment-and without much fanfare-of the federal courts' traditional ability to supply actions at law differing from those in the state.

Burrill also reflected Holmes's odyssey away from his earlier view that the common law provided determinate solutions to legal problems based on customary norms. ${ }^{325}$ His earlier view had been reflected in his opinion for the Court in $O^{\prime} C o n n o r,{ }^{326}$ in which the Court recognized a federal court damages action for illegal taxation without regard to state law. Perhaps reacting to the Court's substantive due process jurisprudence, Holmes seemed to go out of his way this second time around to indicate that common law trespass remedies had no constitutional status. As he put it, "The Constitution standing alone without more does not create a paramount unchangeable liability to an action of tort on the part of all persons who may take any part in enforcing a state law that it invalidates." ${ }^{327}$

321. Judiciary Act of 1789 , ch. $20, \S 34,1$ Stat. 73,92 (1789) (codified as amended at 28 U.S.C. $\S$ 1652 (1994)). For the text of the Act, see supra note 38.

322. See Burrill v. Locomobile Co., 258 U.S. 34, 38-39 (1922).

323. 41 U.S. (16 Pet.) 1 (1842); see also supra notes $37-45$ and accompanying text (discussing Sivift).

324. See, e.g., Smyth v. Ames, 169 U.S. 466 (1898) (holding that a remedy could not be restricted to an action against the state in state court); Tyler, 149 U.S. at 189 (holding that a state's making refund actions exclusive did not affect federal courts); cf. Poindexter v. Greenhow, 114 U.S. 270, 303-04 (1884) (relying on the Rules of Decision Act's exception to the application of state law when the Constitution otherwise requires as a reason to supply a trespass remedy regardless of state limitations when essential to vindicate a right protected by the Constitution); Field, supra note 302, at 511 (stating that, with regard to provisions that statutory remedies be exclusive, "so far as citizens of other states are concerned, even a state statute of this kind can not cut off the common-law remedy against the tax collector, if such nonresidents wish to pursue this remedy in the federal courts").

325. See generally MORTON J. HORWITZ, THE TRANSFORMATION OF AMERICAN LAW, 1870-1960, at 109-43 (1992) (discussing Holmes's changing views).

326. Atchison, T. \& S.F. Ry. v. O'Connor, 223 U.S. 280 (1912).

327. Burrill, 258 U.S. at 38. Justice Holmes continued, "[W]e do not perceive why the State may not provide that only the author of the wrong shall be liable for it, at least when, as here, the remedy offered 
Burrill not only helped to rid the federal courts of actions to recover state taxes, whether brought under diversity or federal question jurisdiction, ${ }^{328}$ but also helped to submerge for some time the previously emergent federal question damages action. Indeed, by allowing a state statutory action to preempt a federal suit for recovery of an unconstitutional tax from the collector, Burrill effectively refused to recognize a federal question suit for damages for trespassory harms under an unconstitutional state law, ${ }^{329}$ a result that was distinctly at odds with the Virginia Coupon Cases ${ }^{330}$ In fact, it was a result that would not be remedied until the Court dusted off $\S 1983$ in Monroe v. Pape ${ }^{331}$ (and, as to federal officers, reinvented an implied damages action in Bivens ${ }^{332}$ ).

What is more, Burrill's reasoning, rejecting the general common law and a fixed common law baseline of protections against government, may suggest not only why federal question damages actions disappeared for a time, but also why they eventually became forgotten. That is, it may indicate why the independent course of federal courts in supplying constitutional remedies was eclipsed by a view that state law causes of action with interstitial federal elements had been the primary means for raising constitutional issues. In the nineteenth century, the federal courts had maintained a barrier between citizen and government by effectively requiring a general law trespass remedy for constitutional violations. To Progressive critics of the federal courts, however, the task at hand seemed to be to lower the common law barriers between citizen and government to allow for majoritarian economic regulation. ${ }^{33}$ But to deconstitutionalize all common law protections against government would have been to throw out the rule of law along with the lainted legacy of Swift t34 $^{34}$ and Lochner. ${ }^{335}$

is adequate and backed by the responsibility of the State " Id.

328. See infra note 337. Burrill had been brought as both a diversity and federal question case See supra text accompanying note 315 .

329. See City Bank Farmers Trust Co. v. Schnader. 291 U.S 24. 29 (1934) (noung that in a diversity equity action challenging a tax on federal grounds, the statutory refund remedy agatnst the state would not be a federal question suit); of. Ford Motor Co. v. Department of Treasury. 323 US 459 (1945) (trealing a suit against individual officers to recover allegedly unconstitutuonal taxes as a statutory action aganst the state that was barred from federal coun by the Eleventh Amendment); Greal $N$ Life Ins Co y Rezd. 322 U.S. 47, 52, 64 (1944) (same). But of. Henrietta Mills v. Rutherford County, 281 U S 121. 127 (1929) (refusing equity jurisdiction in a case alleging unequal assessments in volation of the Equal Prolection and Due Process Clauses of the Foureenth Amendment, but implying that peutuoner would have had a federal question action at law against the collector for taxes collected in violation of the Federal Constitution)

330. 114 U.S. 270 (1884); see also supra note 262.

331. 365 U.S. 167 (1961).

332. Bivens v. Six Unknown Named Agents of Fod. Bureau of Narcolics, 403 U S 388 (197!)

333. See, e.g., Roscoe Pound, Liberty of Contract, 18 YALE L.J 454. 466 (1909) (critugung both the view that the common law was par of the universal legal order and the concomitant narrow attutude toward legislation).

334. Swift v. Tyson, 41 U.S. (16 Pet.) 1 (1842).

335. Lochner v. New York, 198 U.S. 45 (1905). 
Statements of Holmes in Burrill may appear to reject altogether the idea that the Constitution compelled a certain baseline of common law remedies and to conclude that such remedies are within the unfettered control of state legislatures. But the result in Burrill probably does not support such a broad conclusion, despite its clear shift in direction. Indeed, the Court in Burrill seemed to condition the state's substitution of state law remedies that foreclosed federal court remedies on the substantial equivalence of those state remedies to the traditional assumpsit action. ${ }^{336}$ Thus, while Holmes derided the concept of constitutionally required common law remedies, his own opinion seems to require their equivalent, although-significantly-not necessarily in federal court. ${ }^{337}$ Accordingly, even after Burrill, on direct review of state court decisions the Court continued to require states to provide

336. See Burrill, 258 U.S. at 38 (noting that "the remedy offered is adequate and backed by the responsibility of the State"). In Cary v. Curtis, 44 U.S. (3 How.) 236 (1845), the Supreme Court approved what it perceived to be Congress's abrogation of the common law assumpsit remedy against customs collectors and its replacement with an administrative remedy. Congress quickly moved to overturn the result of Cary. See Act of Feb. 26, 1845, ch. 22, 5 Stat. 727; see also Antonin Scalia, Sovereign Immunity and Nonstatutory Review of Federal Administrative Action: Some Conclusions from the Public-Land Cases, 68 MICH. L. REV. 867, 915 n.222 (1970) (discussing congressional reaction); cf. Hart, supra note 93, at 136769 (seeing Cary as resting on the assumption that adequate alternative remedies existed).

337. In addition, federal court assumpsit remedies theoretically could still be available where the state actions provided for nonsovereign defendants or where the remedies against the state were not exclusive. Cf. Matthews v. Rodgers, 284 U.S. 521, 526 (1932) (finding inadequate grounds for equity but noting that if the claimant had a "plain, adequate, and complete" remedy at law, he was left to state courts or to a suit at law in federal court if the elements of federal jurisdiction were present).

Nevertheless, the Court increasingly discouraged litigants from bringing assumpsit-type actions against collection officials in federal court even when Burrill would not have barred them. The Court discouraged plaintiffs from bringing refund actions against state officials, even in non-exclusive remedy situations, by interpreting the litigant's compliance with state statutory prerequisites for suit against the state, undertaken prior to suit against the collector in federal courts, as indicating that the suit was really one under the statute that could only be brought against the state. In Great Northern Life Insurance Co. v. Read, 322 U.S. 47 (1944), the Court (subsequent to the Tax Injunction Act) disallowed an action by a foreign insurance company against the collector, in which the taxpayer claimed that the tax was illegal under the Fourteenth Amendment. The Court stated that it was unnecessary to determine if the action was against the state, because the Court interpreted the petitioner's compliance with certain state prerequisites to bringing suit as indicating that he was in fact suing under such provisions. The Court distinguished cases against collectors that it had once countenanced by indicating that they had been decided under "general law." See id. at 50-51; id. at 64 (Frankfurter, J., dissenting) (arguing that the action should be allowed as an ordinary common law action against officers acting under an unconstitutional statute); see also Ford Motor Co. v. Department of Treasury, 323 U.S. 459, 462 (1945) (holding that the Eleventh Amendment barred a suit that the Court treated as a state statutory refund action but restating the Great Northern Life Insurance Co. dictum permitting such suits brought against state officials in their individual capacity). Compare Great Northern, and Ford Motor Co., with Pickard v. Pullman S. Car Co., 117 U.S. 34 (1886) (allowing a fecleral action after a payment under protest in compliance with a state statute). For other cases restricting federal courts' jurisdiction over suits questioning the legality of state taxes, see California v. Grace Bretlren Churcli, 457 U.S. 393, 407-11 (1982) (indicating that the federal equity practice of avoiding interference with state taxation that Congress approved in the Tax Injunction Act precluded declaratory judgment actions); Fair Assessment in Real Estate Ass'n v. McNary, 454 U.S. 100 (1981) (holding that comity and federalism prevent federal courts from entertaining $\S 1983$ damages actions when state law furnishes taxpayers an adequate legal remedy); and Great Lakes Dredge \& Dock Co. v. Huffman. 319 U.S. 293 (1943) (indicating that the federal practice of avoiding interference with state taxation that Congress approved in the Tax Injunction Act precluded declaratory judgment actions). 
the equivalent of common law trespass or assumpsit remedies to recover unconstitutional taxes. ${ }^{338}$

What is more, federal courts continued to provide injunctive remedies in tax cases until Congress passed the 1937 Tax Injunction Act. Even Holmes distinguished equity actions from actions at law (at issue in Burrill) on the ground that only in the latter cases did the Rules of Decision Act require reference to state law. In equity, remedial rights were still governed by uniform federal decisions. ${ }^{339}$ Thus, federal equity actions brought against individual officers to enjoin illegal state taxes remained available without regard to a state's attempt to make itself the exclusive defendant or foreclose all tax injunctions.

Indeed, Burrill had the effect of making federal tax injunctions easier to obtain, at least prior to the Tax Injunction Act. The Court soon indicated that remedies at law in tax cases were "inadequate" if they were unavailable in federal court-as might more frequently be the case after Burrill. For example, if an exclusive refund action against the state was now available only in state court, the inadequacy of remedies at law could justify a federal court equity action. ${ }^{340}$ This meant that some actions wherein the taxpayer once would

338. See, e.g., Carpenter v. Shaw, 280 U.S 363, 369 (1930) (holding that denal by a stalc court of the recovery of taxes exacted by compulsion in violation of the US Constutution or federal laws contravenes the Fourteenth Amendment); $c f$. lowa-Des Moines Nal'I Bank v. Bennett. 284 U.S 239 (1931) (reversing a state court's denial of a refund remedy in a case where a stale official had exacted laxes in violation of state and federal law). The Supreme Coun in Benueft relied on federal statutory requirements that national banks could be taxed only at the same rate as moneyed capital in the hands of individual citizens of the state and also held that the inequality of treatment volated the Equal Protection Clause See Bennett, 284 U.S. at 244-45; of. Anniston Mfg. Co. v. Davis. 301 U S 337, 342-43 (1937) (relyang on Burrill to hold that, if a fair and adequate remedy had been substituted by the feateral government, that remedy could supersede the traditional action against the federal collector)

339. While equity would follow its own rules, the Court noted that "as to tnals al common law, except when the Constitution, treaties or statutes of the United Stales otherwise require or provide. the laws of the States are the rules of decision." Burrill, 258 U.S. at 38. Bul of. Guaranty Trust Co v York, 326 U S 99. 104 (1945) (taking the view that federal courts had respected state-created substantuve nghts un equity more than in actions at law).

340. See City Bank Farmers Trust Co. v. Schnader, 291 U.S. 24, 29 (1934) (holding in a diversity case challenging a tax on federal grounds that federal equity was appropriale where the remedy in stale coun was against the state and could not be brought in foderal court): Risty v Chicago, R.I \& Pac Ry 270 U S 378,388 (1926) (finding that the inadequacy of remedies at law is tested by the remedies avalable on the law side of federal court); Chicago, B. \& Q.R.R. v. Osbome. 265 U.S. 14. 16 (1924) ("If an action to recover the payment were allowed, the suit might be brought in the Courts of the United States, under the usual conditions, as well as in those of the State. But the wnt of error [remedy allowed by the statel of course can be sued out only in the State, and a remedy in the State Couns only his been held not to be enough." (citations omitted)); see also Franklin v. Nevada-Calıforna Power Co., 264 F 643 (9th Cir 1920) (stating that the adequacy of a remedy at law in state cour was immitertal). ctsed wuh approval in Osborne, 265 U.S. at 16.

The federal courts had long held that the inadequacy of remedies at law was judged by standards that existed in Chancery in 1789, and that the addition of stale remedies all law did not suburact from the availability of federal equity. See supra note 145; see also Smyth v. Ames, 169 U.S. 466,516 (1898). The addition of new state substantive rights, however, might sometumes add to fateral cyuity. See Smyth, 169 U.S. at 516 (citing cases). The tax cases holding that the federal couns should look only to remedies available at law in federal coun, however, gave a slightly new slint to this old doctrine The federal courts prior to Burrill generally had assumed that remedies at law avallable in state courn were avalable in federal court as well (sometimes in modified form) in cases of proper junsdiction. Given this assumption. the 
have been directed to pursue post-payment actions at law (either in state or federal court) could now come within the equity jurisdiction in federal courts, often resulting in anticipatory injunctions against the operation of the $\operatorname{tax}^{341}$

The Tax Injunction Act of $1937^{342}$ ended the expansion of federal equity jurisdiction following Burrill. In that statute, Congress explicitly directed that the adequacy of remedies available in state court would preclude federal equity jurisdiction. The legislative history indicated that the Act's primary targets were out-of-state corporations that were able to invoke federal jurisdiction to enjoin taxes and thus avoid state limitations of tax suits to post-payment refund actions. $^{343}$

\section{Federal Injunctions for State Law Violations}

The apparently obligatory trespass action or its equivalent to remedy taxes violative of federal law may also suggest that the states were required to provide remedies not just for unconstitutional taxation, but also for taxation illegal under state law. ${ }^{344}$ As discussed above, in Ward v. Board of County

inquiry into the adequacy of remedies at law did not distinguish between whether such remedies werc available in state or federal court.

341. In Southern Railway v. Query, 21 F.2d 333, 341-44 (E.D.S.C. 1927), the appeals court initially held, in an action brought under diversity and federal question jurisdiction to enjoin a tax, that adequatc remedies at law precluded the federal court from issuing an injunction. On rehearing, however, the court concluded that the state refund remedy was against the state exclusively, such that remedies at law were inadequate because they were unavailable in federal court. See id. at 344 . The existence of the state refund action in state court thus did not bar the injunctive action in federal court. See id. at 346.

342. 28 U.S.C. \& 1341 (1994).

343. See S. REP. No. 75-1035, at 1-2 (1937). The Senate report stated that most states required refund actions for most tax cases, and that the "existing practice of the Federal courts in entertaining tax-injunction suits against State officers makes it possible for foreign corporations doing business in such states to withhold" taxes. See id. at 1 . It also noted that the report on the Johnson Act, ch. 283, 48 Stat. 775 (1934) (codified at 28 U.S.C. $\$ 1342$ (1994)), "pointed out [that] the continuance of the unjust discrimination between citizens of the State and foreign corporations doing business in such State has been the cause of much controversy." S. REP. No. 75-1035, at 2; $c$. Paul M. Bator, Some Thoughts on Applied Federalism, 6 HARV. J.L. \& PUB. POL'Y 51, 55 (1982) (discussing the possibility of a regime in which the federal remedy might merely provide a "backstop," comparable to the scheme existing under the Tax Injunction Act and the Johnson Act).

344. Professor Field, for example, has noted:

The rule that taxes paid under protest and under compulsion may be recovered even in the absence of statute was formulated by the state courts without reference to any federal constitutional provision, but the opinions in Ward $v$. Commissioners of Love County, and Carpenter v. Shaw, indicate that it might have been forced upon them in time if they had not formulated it themselves.

Field, supra note 302, at 521. Professor Field further observed that it would be a shor step to require remedies for taxes violative of state law. See id.; see also Tatarowicz, supra note 302, at 119 (writing before McKesson Corp. v. Division of Alcoholic Beverages, 496 U.S. 18 (1990), that "[a]lthough there may be a due process right to a refund of unconstitutionally collected taxes in at least certain instances (c.g., for taxes paid under duress), such a right has not been clearly defined"). Both the Field and Tatarowicz articles suggest that, at the time the articles were written, the Supreme Court was not carefully policing remedies at a systemic level even as to taxes that might be violative of federal constitutional provisions. See Field, supra note 302, at 521-31; Tatarowicz, supra note 302, at 128, 134; see also Hart, supra notc 93, at 1369 (stating the belief that a taxpayer has a constitutional right to litigate the legality of a tux, but that the issue has not been squarely presented to the Court because of the multiplicity of remedies and 
Commissioners, ${ }^{345}$ the Court had required the state courts to enterain an assumpsit action for taxes that the Court deemed to have been coercively collected. Although the illegality of the tax in that case was based on federal law, the Court more generally seemed to indicate that the state must provide a monetary remedy for payment under protest of illegal taxes ${ }^{3+0}$ by stating that the failure to provide a remedy for coercively collected unlawful taxes would violate due process. ${ }^{347}$ Similarly, the Virginia Coupon Cases, ${ }^{3: 5}$ while addressing taxes collected in violation of the Federal Constitution, also suggested more generally that the lack of trespass remedies against collectors would violate due process. ${ }^{349}$

Support for a requirement that states supply adequate remedies for taxes illegal only under state law may also be inferred from the federal courts' pre1937 willingness to grant tax injunctions on state grounds when there was otherwise a ground for federal jurisdiction. ${ }^{350}$ For example, federal courts granted a number of injunctions against assessments that taxpayers claimed were systematically unequal in that others were being assessed at a smaller percentage of fair value than the complaining party. Litigants in such equalization cases generally claimed that the assessments violated the Fourteenth Amendment's Due Process and Equal Protection Clauses, and the Court found such claims sufficiently substantial to support federal question jurisdiction. ${ }^{351}$ For a time, however, the taxpayers had clearer claims under

because Congress has seldom if ever tried to take them all awdy)

345. 253 U.S. 17 (1920); see supra notes $306-310$ and accompanying text

346. In addition, the fact that states generally provided common law or subsutute remedies lor illegal taxes paid under protest or duress may indicate that such remedies were required by due process See Field. supra note 302, at 521 (discussing the prevalence of remedies for payment under protest)

347. See Ward, 253 U.S. at 24.

348. 114 U.S. 269 (1884).

349. See supra notes $219-229$ and accompanyıng texi

350. See, e.g., Dawson v. Kentucky Distilleries \& Warchouse Co . 255 U 5 288. 244 (1921) (grantung relief in a diversity action challenging a tax on state and tederal grounds based on unulorm laxulun provisions of the state constitution); Cummings v. National Bank. 101 U S 153. 15.4-56 (1879) (providing an equitable remedy for violation of a state constutution after rejectung a federal statutory clasm) The Coun in Cummings noted that the state allowed injunctions aganst collection as well as suts for recuvery of taxes, but indicated that the federal coun in equity could provide an injunctuon whether or not the stale provided for it when there was an unequal system of assessment affectung many persons See Cumurungs. 101 U.S. at 157-58. The Coun apparently allowed the bank to sue although the tax was technically on the shareholders, and the state courts apparently would not have allowed the bank to sue See ad at 156-57. cf. Reagan v. Farmers' Loan \& Trust Co., 154 U.S. 362, $390-91$ (1824) (notung that the cunstitutionality of states' taxing statutes would not deprive federal courts of jurisdiction to redress unlawful taxalton because the officer might go beyond the statutory power conferred on him to assess and cullect taxes. thereby working an illegal trespass upon property nghts of individuals); County of Sanls Clara v Suuthem Pac. R.R., 118 U.S. 394, 410-11 (1885) (deciding that certan propeny could not properly be tuxed under state law and avoiding decision on a federal due process challenge to state taxituon scheme) Southem Pacific Railroad was an enforcement action removed from state cour at $\$$ ume when federal delense removal was allowed. See supra notes 106, 263.

351. See, e.g., Greene v. Louisville \& I.R.R., 244 U S 499. 508 (1917). Raymond v Chicagu Uniun Traction Co., 207 U.S. 20, 35 (1907). In Raymond, the Court indicited that d federal question clesrly aruse in a case alleging the systemic undervaluation of others' propery in the state See 207 U S at 21 The Cour seemed to hold that the Fourteenth Amendment was voldted in the state bosud's fulure to equalize assessments as required by the state constitution See id at 35 It was. however, uncleat it the Coun 
state constitutional provisions explicitly directing equal assessments. Thus, federal court tax injunctions in equalization cases were often based on state law grounds, with the federal courts avoiding decision of the federal constitutional issue. ${ }^{352}$ Oddly, tax injunctions on state law grounds were frequently based on pendent jurisdiction in federal question cases, while tax injunctions on federal constitutional grounds were frequently granted in diversity cases. ${ }^{353}$

As was true of equitable remedies for taxes illegal under federal law, federal equity courts in cases alleging violations of state law paid little heed to state court limitations on remedial rights. Their main concern was whether federal requirements for the exercise of equity jurisdiction had been satisfied. ${ }^{354}$ Indeed, in one federal court equalization case grounded in state law, the state officer defendants showed that the state supreme court had held that unequal assessments were only administratively and not judicially remediable at all, even though such assessments violated the state constitution. ${ }^{355}$ The U.S. Supreme Court nevertheless held that it was appropriate for the federal courts to grant judicial remedies for the state-created primary right, despite the absence of remedial rights in the state courts. ${ }^{356}$ The Supreme Court also ignored state sovereign immunity defenses in cases

affirmed the grant of an injunction based on state or federal grounds. See id. at 35-40. Elsewhere, the Supreme Court has indicated that systemic undervaluation of other propertics constitutes an equal protection violation. See, e.g., Allegheny Pittsburgh Coal Co. v. County Comm'n, 488 U.S. 336, 343-46 (1989) (holding on direct review that systemic gross disparities in assessed values based on whether land had been recently sold violated equal protection); Cumberland Coal Co. v. Board of Revision, 284 U.S. 23, 28 (1931) (stating on direct review from state court that it is "established that the intentional, systematic undervaluation by state officials of taxable property of the same class belonging to other owners contravenes the constitutional right of one taxed upon the full value of his property"); Sioux City Bridgc Co. v. Dakota County, 260 U.S. 441, 446 (1923) (indicating on direct review from state court that assessment of property at full value while other property is not so assessed violates the Fourtecnth Amendment); Sunday Lake Iron Co. v. Township of Wakefield, 247 U.S. 350, 352-53 (1918) (stating that "it must be regarded as settled that intentional systematic undervaluation by state officials of other taxable property in the same class contravenes the constitutional right of one taxed upon the full value of his property"). The Court in Sunday Lake nevertheless affirmed the state court's denial of relief on the ground that the one-year inequality was not incompatible with a nondiscriminatory attempt to adjust valuations. See 247 U.S. at 353.

352. See, e.g., Hopkins v. Southem CaI. Tel. Co., 275 U.S. 393, 403 (1928) (granting an injunction based on a holding that a state gross receipts tax was to be exclusive of other taxes under state law, without reaching a Fourteenth Amendment question); Greene, 244 U.S. at 520-21 (sustaining an injunction on state law grounds in a federal question equalization case); Cummings, 101 U.S. at 154, 163 (sustaining an injunction in an equalization case on state law grounds, in a case in which jurisdiction was likely based on the bank's federal charter).

353. See supra note 291 and accompanying text.

354. See Union Pac. R.R. v. Board of County Comm'rs, 247 U.S. 282, 283 (1918) (holding that federal equitable jurisdiction was appropriate for a claim that a company's property was assessed at onethird of value while most other property was assessed at one-fifth or not at all, contrary to the state and federal constitutions); Greene, 244 U.S. at 500 (granting an injunction in a federal question case where there was a systemic valuation problem that violated the state constitution); Cummings, 101 U.S. at 158 (granting an injunction on state law grounds and stating that equity jurisdiction was proper where unequal assessment applied to a large class of individuals or corporations).

355. See Greene, 244 U.S. at 512-13.

356. See id. 
brought in federal court alleging that taxes were illegal under state law, so long as the cases were properly pleaded against individual officers for injunctive relief. ${ }^{357}$

The federal courts' provision of equitable remedies for violations of state law without strict regard for remedial rights available in state court therefore may suggest that the Court assumed that adequate remedies for illegal taxes had to be available. However, in the particular suits, the remedy was supplied by the federal courts themselves (when jurisdiction otherwise existed) rather than by a requirement that states entertain tax injunctions. ${ }^{358}$ The federal courts' refusal to recognize sovereign immunity defenses for state officials sued to enjoin violations of state law as well as federal law similarly suggests that remedies in the nature of trespass against tax officials were compulsory in both cases. If adequate remedies against officers for violations of state law were completely optional, the Court arguably should have respected the states' claims of immunity -as the Court would later do in Pennhurst State School $\&$ Hospital $v$. Halderman ${ }^{359}$ for claims involving structural relief against state officers sought on state law grounds.

The Tax Injunction Act, the main purpose of which was to effectuate state restrictions on tax cases to state court refund actions, was directed at halting federal court injunctions entered on both federal law and state law grounds. It was inoperative, however, if the state failed to provide a "plain, speedy and efficient remedy." ${ }^{360}$ The implication of the Act at the time was that, if state remedies at law were inadequate, federal courts with jurisdiction could enter injunctions on both federal and state law grounds. The Act, while ultimately effective in directing litigants to refund actions, reflected Congress's background assumption that states must provide tax remedies where the illegality of the tax is based either on state or on federal law, on pain of renewal of federal jurisdiction in their absence. ${ }^{361}$ While decisions such as Pennhurst might undermine such assumptions concerning taxes illegal only under state law, the Court's and Congress's old approach to the problem

357. See id. at 506-07 (rejecting a sovereign immunty defense in a federal question case in whuch the Court sustained an injunction on state law grounds); of. Siler v. Lousville \& N.R.R. Co 213 U S 175. 194 (1909) (granting an injunction against a rate order in a case brought under federal question junsdiction based on the commission's not having powers to enter such orders under stitc law); John P Dwyer. Pendent Jurisdiction and the Eleventh Amendment, 75 CAL. L. REV. 129 (1987) (arguing that the holding in Pennlurst State School \& Hospital v. Haldennan, 465 U.S. 89 (1984), that the Eleventh Amendment barred actions based on state law grounds, should be limited to institutional reform litıgalıon and should not bar negative relief); David L. Shapiro, Wrong Tums: The Eleventh Amendment and the Pennhurst Case. 98 HARV. L. REv. 61, 83 (1984) (criticizing the Penniturst majonty's casual dismissal of the authonty. stripping rationale as a fiction).

358. Cf. Har, supra note 17, at 507 n.59 (observing that there may be requirements that the states make available post-conviction remedies, but that the federal courts have addressed the problem by supplying remedies themselves).

359. 465 U.S. 89 (1984).

360. 28 U.S.C. $\S 1341$ (1994).

361. See, e.g., Georgia R.R. \& Banking Co. v. Redwine. 342 U.S 299 (1952) (granung an injuncuon against a tax violating a promise in a corporate chanter after remedies in stitc coun proved inadequate) 
suggests that they thought that the Constitution (through the Due Process Clause ${ }^{362}$ ) might require the states to provide an adequate system of remedies for violations of state law.

That a background trespass remedy may have been in some sense constitutionally compelled, however, did not mean that all suits seeking trespass remedies against state officers became federal question cases for purposes either of direct review or for original federal question jurisdiction. Indeed, to become a federal question case, a salient federal issue ordinarily had to be presented in addition to the trespass. ${ }^{363}$ This was manifest both in the cases that the Court reviewed from state courts, ${ }^{364}$ and in the requirement of a substantial federal question for original federal court actions. Nevertheless, the presumptive availability of trespass remedies suggests that, if the state systematically left unremedied certain officer trespasses that violated state law, a due process violation and a federal question for federal court consideration might then be presented.

\section{THE MODERN SignifiCANCE OF THE HISTORY OF CONSTITUTIONALLY COMPELLED REMEDIES}

The history of constitutionally required remedies in state and federal courts sheds light on a pair of unresolved issues in modern federal courts scholarship. The first concerns the frequent suggestion that sovereign immunity may not be a bar to actions against the state for the vindication of federal rights in state courts. ${ }^{365}$ This Article concludes that sovereign immunity may indeed be a bar to the Supreme Court's forcing of broader affirmative remedies on state courts than would be available in federal courts. The Supreme Court's seeming power to provide for damage remedies against states in state courts is ultimately derivative of its power to award relief against individual officers. ${ }^{366}$ The second concerns the relegation to state courts of certain claims alleging trespassory invasions of liberty and property undertaken by state officials in the line of cases associated with Parratt v. Taylor. ${ }^{367}$ This

362. See supra text accompanying notes $306-310$.

363. See, e.g., Greene v. Louisville \& I.R.R., 244 U.S. 499, 504-05 (1917) (deciding a federal question case on state law grounds where the Court perceived a substantial Fourteenth Amendment question); see also Siler v. Louisville \& N.R.R., 213 U.S. 175 (1909) (deciding a Fourteenth Amendment federal question challenge on state law grounds).

364. See, e.g., lowa-Des Moines Bank v. Bennett, 284 U.S. 239, 244 (1931) (reversing a state court's denial of a refund remedy where there was an alleged system of assessing national banks at a higher rate than other monied capital in the state, in violation of a federal law that allowed national banks to be taxed); Carpenter v. Shaw, 280 U.S. 363, 369 (1930) (requiring a refund remedy despite an apparent failure to meet the state requirement of timely payment where Native American taxpayers claimed a federal exemption); Ward v. Board of County Comm'rs, 253 U.S. 17, 24-25 (1920) (requiring a nonstatutory refund remedy for payments made under protest to a county where a federal tax exemption was claimed).

365. See infra sources cited notes 393-394 and accompanying text.

366. See Vázquez, supra note 229 , at $1724,1778$.

367. 451 U.S. 527 (1981). 
Article concludes that although states may be constitutionally required to supply trespass remedies against their officers, it is nevertheless appropriate as both a historical and a normative matter not to treat all such cases as raising federal questions.

\section{A. Sovereign Immunity and Compelled Remedies in State Courts}

Recent decisions of the Supreme Court have required retroactive compensation by the state for taxes collected in violation of the Constitution through remedies in state court. $^{368}$ Such decisions may look somewhat anomalous in light of current doctrine surrounding $\S 1983$ and state sovereign immunity. ${ }^{369}$ In requiring states to provide retroactive compensatory remedies against themselves in their own courts, the Supreme Cour seems to require state courts to provide remedies that are beyond those available in federal courts $^{370}$ - that is, compensatory, non-immunized remedies against the state itself. Because of sovereign immunity, the federal courts (if they entertained tax refund suits) could supply remedies only against individual officers, not against the state. ${ }^{371}$ And under $\S 1983$, monetary remedies might be blocked by individual immunities. ${ }^{372}$ The remedy that the Court requires of the state therefore is not a $\S 1983$ suit, but rather a remedy created by state law.

368. See Reich v. Collins, 115 S. Ct. 547, 549 (1994) (holuing that a state could not hold out a seemingly clear and certain post-deprivation remedy and then declare that no remedy existed for taxes paud under unconstitutional statutes); Harper v. Virginia Dep't of Taxalın. 509 U S 86 (1993) (requinng a state to provide a remedy for taxes that violated federal law): McKesson Corp v Division of Alcoholic Beverages \& Tobacco, 496 U.S. 18 (1990) (reversing the state's denial of a statutory refund temedy for a tax under a statute violating the Commerce Clause)

369. See Mark R. Brown, De-Federalizing Conunon Law Tors: Empashy for Parrat. Hudsun and Daniels, 28 B.C. L. REV. 813,841 (1987) (noting that requinng states to adopt state tor clasms acts would raise sovereign-immunity problems); Fallon, supra note 17, at 356 ("It seems unthinkable thal a state should have to furnish broader remedies for its officials' torts than would be avalable under the immunity doctrines applicable to constitutional actions in federal cour."). Fallon \& Meltzer, supra note 119. al 1825 (stating that the holding in McKesson, although supported by precedent, poses a puzzle when compared with doctrines applicable in other suits seeking monetary relief aganst the state)

370. See National Private Truck Council v. Oklahoma Tax Comm'n. 515 U.S 582. 588-89 (1995) (stating that state courts cannot refuse to awand relief merely bocause a federal coun could not grant such relief).

371. Monetary remedies could be imposed on local political subdivisions for taxes under their unconstitutional statutes or policies. See Monell v. Department of Soc. Servs., 436 U S 658. 690-91 (1978) The Court has held that states are not suable as "persons" under $\$ 1983$. See Will v Mlichigan Dep't of State Police, 491 U.S. 58, 64 (1989).

372. See David Zensky, Parratt v. Taylor: Unauthorized Deprisanons and the Content of an Adequase Remedy, 16 N.Y.U. REV. L. \& SOC. CHANGE 161, 220 (1987-1988) (noing the difficulty of arguing that a qualified immunity equivalent to that applied in federal coun makes a state coun remedy inadequatc). cf. Jack M. Beermann, Government Official Torts and the Takings Clause "Federalism and State Sov eretgn Immunity, 68 B.U. L. REV. 277, 283 (1988) (arguing that the states should not be able to immunize governmental tors if private actors would be liable for the same torts under state law) Even in state courts. a $\$ 1983$ remedy would not be available against the state or an arm of the state. despite the state courts' concurrent jurisdiction over $\$ 1983$ cases. The Court established the lımitation on stale coun $\$ 1983$ actions against the state not because of state sovereign immunity. but because of the Court's reading of suable "persons" under § 1983. See Will, 491 U.S. at 64-71. 
Perhaps tax remedies were fortunate in being arrested in their development by the Tax Injunction Act and the reluctance of federal courts ${ }^{373}$ to entertain refund actions. They were thus spared from having to go forward as $\S 1983$ cases, which became subject to a growth industry of individual officer immunities as $\S 1983$ expanded beyond traditional trespassory harms. ${ }^{374}$ Traditional common law actions against collectors characteristically did not carry with them any good faith immunities (as was true historically for most actions for tangible trespass). ${ }^{375}$ Because of their pre- $\S 1983$, pre-immunity law development, adequate tax remedies (now under state law) at least theoretically continued to require the equivalent of the trespass action against the collector without regard to his good faith, which most states have supplied by way of a state law refund action running against the treasury. ${ }^{376}$ As noted above, ${ }^{377}$ Congress itself may have implicitly recognized such a right in the Tax Injunction Act's admonition that the absence of a plain, speedy and efficient remedy could justify invocation of federal equity jurisdiction. ${ }^{378}$

The requirement of a remedy even for taxes that violate the Federal Constitution, however, is not one that the Court historically forced on the states by way of suits against the states themselves. ${ }^{379}$ The baseline required remedies were typically ones that ran against the individual, not the state, and sovereign immunity would not have barred such officer actions if they had originated in the federal courts. The Virginia Coupon Cases showed how the state was required to maintain trespass actions against its officers, despite state statutory repeal of the cause of action. They also allowed a comparable action to be brought in federal court. ${ }^{380}$ Similarly, in General Oil v. Crain, ${ }^{381}$ where the state courts had general equity jurisdiction that state statutes had not restricted in tax cases, the Supreme Court effectively compelled the state to entertain an action to enjoin a trespass against a state collection official personally. And a similar action could have been brought in federal court. ${ }^{382}$

373. See supra note 337.

374. See Woolhandier, supra note 302 , at $460-77$.

375. See id. at 414-17, 436. But cf. Dinsman v. Wilkes, 53 U.S. (12 How.) 390, 403.04 (1851) (noting that although an officer could not be liable if he erred in his decision that a marine was not entitled to discharge, he could be liable either for bad faith in punishment or regardless of motive if punishment were forbidden by law or beyond his powers); Wilkes v. Dinsman, 48 U.S. (7 How.) 89, 129-30 (1849) (holding that a lieutenant commander would not be liable for a mistake of judgment in a determination that a marine was not entitled to discharge and in detaining and punishing him).

376. See S. REP. No. 75-1035, at 1 (1937) (reporting on the Tax Injunction Act).

377. See supra text accompanying note 361 .

378. See 28 U.S.C. § 1341 (1994).

379. See supra notes 204-244 and accompanying text; see also Vázquez, supra note 229, at 1774 (noting that tax remedies ran against individual officers).

380. See White v. Greenhow, 114 U.S. 307, 308 (1884).

381. 209 U.S. 211 (1908).

382. Crain seems more difficult than Poindexter in light of the fact that the Supreme Court has also allowed state legislatures to foreclose equitable remedies in tax and other categories of cases. See McKesson Corp. v. Division of Alcoholic Beverages, 496 U.S. 18, 37 (1990) (noting that it is wellestablished that the state need not provide a pre-deprivation process for the exaction of taxes); $f$. supra notes 215-218 and accompanying text (discussing the Court's allowance of a substitution-of-refund remedy 
Interestingly, the Court's decisions appeared to treat sovereign immunity as equally inapplicable in state and federal court actions against individual officers to remedy trespassory harms. ${ }^{383}$

To be sure, the Court on direct review sometimes awarded affirmative remedies against the state itself. But these cases were ones in which the state had consented to a suit in state court-generally manifested by the state courts having entertained the action-and in which the state cour had merely denied relief on the merits. ${ }^{384}$ In such cases, there was an involuntary suspension of sovereign immunity primarily in the sense that the state could not limit its consent to be sued so as to foreclose Supreme Court review. ${ }^{335}$

The older cases in which the Supreme Court took jurisdiction over actions where plaintiffs sought affirmative remedies against the state itself therefore manifested the Court's approach of taking state courts as it found them when

for mandamus). Crain presents an odd combination of the compulsory and the voluntary. The Supreme Coun in Crain would not have forced the state to supply equitable remedies. But if the state cour exeressed general equitable jurisdiction it could be required to exercise such jurisdiction to enjoin an imminen trespass by a government officer, just as the state courts might be required to entertann a damages action for a completed trespass. In Georgia Railroad \& Banking Co v: Musgrove, 335 U S. 900 (1949) (per curiam), however, the Court allowed the state court to hold the collector immune from an injuncion in state court. The Cour then allowed the same suit to be brought aganst the offices in federal coun for a tax violative of the Commence Clause. See Georgia R.R. \& Banking Co. v. Redwine. 342 U S 299. 30406 (1952). The result in $M$ usgrove may reflect a greater respect for state judge-made law than the result in Crain.

That states were not forced generally to have equitable remedies did not exactly mean that equatable remedies were not constitutionally compelled, since the federal courts were often avalable to provide them when jurisdiction existed. The availability of foderal equity kept the issue of when state courts must entertain injunction actions from surfacing very often. Issues of mandatory remedies in stale coun seem to arise most often today in areas of tax and eminent domain, where federal junsdiction is restricted.

383. See Hopkins v. Clemson Agric. College. 221 U.S. 636 (1911) (reversing a state court's decision that there was a sovereign immunity bar to the plaintiff's claim that the college's nooding of the platnufr's land without compensation violated due process); Crain, 209 U.S. 211 (1908); Poindexter v. Greenhow. 114 U.S. 270 (1884).

384. See Curran v. Arkansas, 56 U.S. (15 How.) 304, 309, 320 (1853) (holding that the Supreme Court could entertain review of an equity action to restore funds that the stale had withdrawn from a bank because state courts had held that the state could be sued and thus had consented to sutt); see also fargo v. Michigan, 121 U.S. 230 (1887) (reversing on the merits the state courts denial of an injunction against the state auditor's collection of a tax on the grounds thit the tax violated the Commeree Clause). Woodruff v. Trapnall, 51 U.S. (10 How.) 190, 209 (1850) (reversing the denial of mandamus against a state treasurer on the merits, stating, "In sustaining the application for a mandamus, the Supreme Coun of the State exercised jurisdiction in the case. To that court exclusivcly belongs the question of its own junsdiction."). Armstrong v. Treasurer of Athens County, 41 U.S. (16 Pe.) 281. 286 (1842) (refusing to consider an ussue of misjoinder and stating that "[t]he Supreme Coun of Ohjo having enterained junsolicuon, this Coun must do so likewise"). See generally Jackson, supra note 190, at 27-28 (discussing cases in which the Court found that state law controlled whether the state was suable in state court).

385. The state's consent, however, will not generally extend to suts brought in lower federal courts See Smith v. Reeves, 178 U.S. 436, 441, 445 (1900) (holding that a state could limut its consent to be sued for tax refunds to its own courts, subject to Supreme Court review). Professor Vicks Jackson seems to reject a consent theory to explain the Supreme Courts providing remedies against states on durect review, noung that an absolute bar on jurisdiction should not be waivable by consent, and that a state cannot effectively limit its consent to affirmative relief against the state so as to preclude Supreme Cour review. See Jackson. supra note 190, at 35-37, 39. Jackson sees these latter two phenomena as betler explaned by her revisionist view that the Eleventh Amendment does not constrain foderal question jurisdiction. See id. at 39 She uses a doctrine of abstention to explain why claims for affirmative relief will be heard in stale coun with Supreme Coun review rather than in lower federal courts. See $t d$. at 74 
it engaged in direct review. ${ }^{386}$ Where states provided no remedies against themselves as part of their remedial structure, however, the Court historically did not compel such unwilling state courts to provide them; the individual officer was a sufficient target. Indeed, the Court refused to restore remedies against states even in Contracts Clause cases where it otherwise would have restored remedies available against nonsovereign parties at the time of contracting. ${ }^{387}$ To this extent, therefore, state assertions of sovereign immunity in state court were historically respected.

More recent decisions of the Court suggest that state consent to suit appropriately may be found in contexts besides those in which state courts had themselves entertained suits against the state but merely denied relief on the merits. These decisions have arisen when state statutes provided for taxpayer actions against the state, but the state courts, while finding the taxpayer correct on the merits, nevertheless denied a refund remedy. Thus in Reich $v$. Collins, ${ }^{388}$ state legislation made refund actions available against the state, but the state court held as a matter of state law that refunds nevertheless should not be available for taxes paid under statutes declared unconstitutional only subsequent to payment of the taxes. The U.S. Supreme Court in Reich did more than reverse on the merits; it forced the state court to provide a refund remedy that the state court had held was unavailable as a matter of state law. The Supreme Court's disposition of Reich arguably forced the state to provide remedies against itself beyond any consent to suit that the state had given. ${ }^{389}$

Cases such as Reich, however, are nevertheless justifiable by a notion of consent. The state legislature had substituted an action against the state (which historically the Supreme Court could not require) for traditional trespass or assumpsit actions against the officer for damages (which historically the Supreme Court could require). The state, however, after substituting the remedy, purported to make its remedy unavailable in a particular class of cases where the remedies against the officer would have been constitutionally compelled - that is, cases concerning taxes collected under unconstitutional statutes. ${ }^{390}$ In the past, the Supreme Court could have required the state, in the absence of adequate alternative remedies, to entertain a trespass or

386. See supra note 180 .

387. See supra notes 195-212 and accompanying text.

388. 513 U.S. 106 (1994).

389. While state legislation allowed generally for a refund remedy, the state supreme court held it was unavailable when the tax was collected under a statute that was later declared to be unconstitutional. See id. at 109. Because we now tend to see state judge-made law as a form of state law that is for the most part equivalent to legislative law, the remedy in Reich can be seen as lacking state consent despite the legislative authorization for refunds.

390. See id. (requiring a state to provide refund remedies where its statutes made refunds available but where the state supreme court had held they were not available for tax under a statute later declared to be unconstitutional); McKesson Corp. v. Division of Alcoholic Beverages \& Tobacco, 496 U.S. 18 (1990) (reversing the state cour's denial of a refund remedy for a Commerce Clause violation where the state provided for refund actions but the state court had denied a remedy based on the state agency's good faith reliance on a statute). 
assumpsit action against the collector individually, even though such required actions were exceptions from the states' presumptive control over causes of action in their own courts. ${ }^{391}$ Accordingly, in a case such as Reich, the Court presumably would have had the power to force the state to entertain an immunity-free assumpsit action against the collector if the state were unwilling to provide a comparable remedy against itself.

The power to force a remedy against the individual officer therefore remains the basis for requiring a remedy against the state, even in contexts such as Reich. ${ }^{392}$ Yet, it is arguably more respectful of the state's structuring of its refund remedies for the Supreme Court on direct review-as in Reich-simply to reverse the decision denying a refund remedy against the state once the state has otherwise made itself suable for tax refunds. The end result is that the state, having substituted itself for the individual officer, cannot avoid the baseline compensatory remedial requirement for certain types of cases. In reversing as it did, the Supreme Cour thereby accommodated constitutionally compelled remedies to the state's own choice of remedial structures.

This analysis of Reich may be inconsistent with the conclusions reached by some scholars ${ }^{393}$ and Justices ${ }^{394}$ that sovereign immunity concerns are not implicated in state court lawsuits redressing unconstitutional state action that come to the Supreme Court on direct review. Their conclusions are obviously true in the sense that the Supreme Court can review causes of action that the state courts themselves entertain and that the Eleventh Amendment would bar from other federal courts. Their conclusions also are true in the sense that the Court may accommodate required constitutional remedies to state remedial frameworks. But if their conclusions mean to indicate further that Congress $^{395}$ and the Court have broader powers to force states to recognize

391. See supra notes 219-229, 306-310 and accompanying text.

392. See Vázquez, supra note 229, at 1771 (expressing a sımular view)

393. See Jackson, supra note 190, al 6-7 (concluding from the Supreme Court's routune review of claims against states for monetary relief on review from state courts that the Eleventh Amendment does not apply to federal questions but operates as a form of abstention mandatung that state couns have the first opportunity to consider cenain claims for relief arising under foderal law): Monaghan, supra note 22, at 122 (stating that the Eleventh Amendment serves pnmarly as a forum allocauon device) Direct review of cases where the state is enforcing its laws or is otherwise a plaunuff poses less of an Eleventh Amendment problem than the cases for affirmative relief agaunst the state. See Jackson, supra note 190. at 23-24 (discussing the theory in Cohens v: Virginta, 19 U.S. (6 Wheat.) 264 (1821), that the action is not against the state); $f$. Hart, supra note 17, at 516 ("In cases coming to the Supreme Court from the state courts the Eleventh Amendment is inapplicable.").

394. See Employees of Dep't of Pub. Health \& Welfare v. Department of Pub Health \& Welfare. 411 U.S. 279, 287 (1973) (Marshall, J., concurring) (statung that Congress could lift state ummunity from a suit in state court even when it could not do so in federal court): cf. McKesson. 496 U.S at 27 (statung that it is settled that a writ of error to review a final judgment against a statc, even where the state is a defendant and is successful in the lower cour, is not a suit barred by the Eleventh Amendment). Will y Michigan Dep't of State Police, 491 U.S. 58 (1989) (concluding that, while the Eleventh Amendment was not a bar to actions in state coun, the state was not a suable "person" under $\S 1983$ ).

395. Arguments as to congressional ability to abrogate state sovereign immunity have focused primarily on abrogation in federal court. To the extent Congress can abrogate state immunity in federal 
causes of action against themselves in state courts than in federal courts, then the statement is highly problematic, at least as a historical matter. Contrary to such a conclusion, the Court's past practice suggests that the availability of an action against the state itself is largely within the control of the state-at least for those cases that the Eleventh Amendment would bar from a federal trial court. The Constitution may require states to provide meaningful remedies, but the Court's decisions do not support the view that the Supreme Court may require the state to supply remedies against themselves.

\section{B. Common Law Remedies and the Constitution: Old Light on a Modern Dilemma}

The tax remedy cases and the history of the emergence of federal question cases more generally also provide insight into the difficulties surrounding the line of cases associated with Parratt $v$. Taylor. ${ }^{396}$ They may even suggest that the Court has struck the proper balance in these cases between the constitutional requirement of trespass remedies against state and local officials and the desire not to federalize all such remedies. ${ }^{397}$

court, its ability to abrogate state immunity in state court may follow as a matter of course, insofar as the Court has required state courts to entertain federal causes of action absent a valid excusc. See, e.g., Testa v. Katt, 330 U.S. 386 (1947). For a time, however, the Court appeared to take the position that congressional abrogation of state immunity in state court might be more permissible than abrogation in federal court. See Hilton v. South Carolina Pub. Rys. Comm'n, 502 U.S. 197 (1991) (allowing a Federal Employers' Liability Act suit in state court against the state despite the Court's prior overturning of precedent that had made states liable to such suits in federal court); id. at 206 (noting that it was generally desirable to interpret statutes as abrogating sovereign immunity to the same extent in both state and federal cour, but indicating that respect for stare decisis militated in favor of preserving the remedy for statc railroad workers); Welch v. Texas Dep't of Hwys. \& Pub. Transp., 483 U.S. 468 (1987) (holding that Congress was not sufficiently explicit to abrogate sovereign immunity in a federal Jones Act case); id. at 495 (White, J., concurring) (indicating that the Court's holding that a federal court Jones Act action was unavailable due to lack of congressional explicitness should not be read as precluding a Jones Act suit in state court); see also Employees of Dep't of Pub. Health \& Welfare, 411 U.S. at 287 (Marshall, J., concurring) (arguing that states could be sued in state courts on Fair Labor Standards Act claims even if Congress could not abrogate immunity in federal court).

This Article does not address the scope of congressional ability to abrogate state sovereign immunity, but it does conclude that congressional ability to abrogate is no broader as to state courts than as to federal courts. See generally Seminole Tribe v. Florida, 116 S. Ct. 1114 (1996) (holding that Congress lacked the power to abrogate sovereign immunity under the Commerce Clause); Martha A. Field, The Eleventh Amendment and Other Sovereign Immunity Doctrines: Congressional Imposition of Suit upon the States, 126 U. PA. L. REV. 1203 (1978) (arguing that sovereign immunity is a common law doctrine that Congress may abrogate in both state and federal court).

396. 451 U.S. 527 (1981); see also Daniels v. Williams, 474 U.S. 327 (1986) (holding that mere negligence by a state of ficer cannot constitute a deprivation of liberty or property under the Fourteenth Amendment, such that there was no due process violation even if the state provided no post-deprivation process); Hudson v. Palmer, 468 U.S. 517 (1984) (holding that no $\S 1983$ action was available for intentional destruction of a prisoner's property during a shakedown because the state's adequate postdeprivation remedies satisfied due process).

397. See generally Brown, supra note 369, at 816-17 (agreeing with the Supreme Court that the Duc Process Clause should not be interpreted to make ordinary tort actions against officials into federal court claims); Rodney A. Smolla, The Displacement of Federal Due Process Claims by State Tort Remedies: Parratt v. Taylor and Logan v. Zimmerman Brush Company, 1982 U. ILL. L. REv. 831, 867 (concluding that $\S 1983$ and the Due Process Clause often would not improve on the well-tailored balances of common 
Parratt excludes from $\S 1983$ litigation suits against public officials for ad hoc deprivations of nonfundamental liberty and property interests that can be addressed by the state tort system. ${ }^{398}$ Such federal-court-excluded invasions involve nonfundamental rights, in the sense that the defendant has not violated a specific guarantee of the Constitution or the Bill of Rights or committed acts that invoke heightened scrutiny under the fundamental rights strand of the Due Process Clause or other constitutional provisions. Rather, in such cases the official has only violated the Due Process Clause simpliciter ${ }^{399}$ by trenching on a traditional common law interest in liberty or property. ${ }^{ \pm 00}$ If, for example, a teacher were summarily to inflict corporal punishment on a student, the student might complain that he had been deprived of his libery interest in bodily integrity. In such cases, the Due Process Clause may be implicated, but the protection it generates is primarily seen as procedural in the sense that the state may have to provide a meaningful post-deprivation state remedy to redress the governmental illegality. ${ }^{401}$

Parratt has drawn criticism because of its poor fit with the state action and irrelevance-of-state-remedies aspects of modern $\S 1983$ jurisprudence. ${ }^{ \pm 02}$ Monroe v. Pape ${ }^{403}$ manifested a long-term development by which "unconstitutional" action-which in the nineteenth century focused on the validity of statutes-came to be seen as also including ad hoc illegality on the part of public officials, even when it was unauthorized by state law. ${ }^{\text {tas }}$ According to Monroe, an official engages in state action and action "under color of state law" even when he acts contrary to state law. line of cases is arguably inconsistent with this state action aspect of Monroe, insofar as it reasons that (absent a systemic problem) the state has not denied due process until the state court system has itself denied relief. ${ }^{.06}$ Parratt is

law protections for traditional common law interests).

398. But cf. Brown, supra note 369, at 831 n.130, 854 (noting that one could argue that the Parratt

Court merely held that the state post-deprivation remedies were sufficient, though not necessary)

399. Alternatively, the official may have violated the prohibition on uncompensated takings.

400. See Beermann, supra note 372 , at 284 n.24.

401. Such cases may, however, obtain a federal forum where the allegation is one of a stalutory or systemic due process violation. See Logan v. Zimmerman Brush Co., 455 U.S. 422 (1982) (holding that there was a due process violation where the state system destroyed the plaintiff's cause of action for employment discrimination after a state commission failod to convene a heanng on the complant within 120 days).

402. See Brown, supra note 369, at 850-60 (discussing Parrasr's appanent inconsistency with modem state action and due process doctrines).

403. 365 U.S. 167 (1961).

404. See Home Tel. \& Tel. v. City of Los Angeles, 227 U.S. 278, 287.96 (1913): Henry Paul Monaghan, State Law Wrongs, State Law Remedies, and the Fourteenth Amendment, 86 COLUM. L. REY. 979, 981,999 (1986); see also Bator, supra note 343, at 52.53 (discussing Monroe as rellectung the theory that the Fourteenth Amendment and $\$ 1983$ proted against state official action cyen without a showing that the action was authorized); William Bumham, Separating Constitutsonal and Common.Low Toris: $A$ Critique and a Proposed Constitutional Theon' of Dury, 73 MINN. L. REv. 515.515 (1989) (staning that before Monroe, courts assumed that torts that violated state law could not be "under color of state law") 405. See Monroe, 365 U.S. at 172.

406. See Monaghan, supra note 404 , at 981 . 
also in tension with Monroe's holding that $\S 1983$ remedies are supplemental to state remedies and that a litigant need not make a showing of inadequacy of state remedies to bring suit under $\S 1983 .{ }^{407}$ Parratt seems to limit federal court actions addressing isolated nonfundamental deprivations precisely to cases in which the litigant can show such remedial inadequacy. ${ }^{408}$ Scholars have noted, however, that the silver lining of Parratt may be its implication that the state is required to maintain a system of adequate (state) remedies for violations of nonfundamental rights- that is, rights that are largely created and defined by state law - and that the absence of such a remedial system could occasion federal court action under $\S 1983 .^{409}$

If the complaint against Parratt is its inconsistency with some strands of modern constitutional and $\S 1983$ developments, ${ }^{410}$ a partial response may be that its results are nevertheless consistent with still other precedent. On the one hand, history (at least inferentially) supports viewing the Constitution as compelling a system of adequate state law remedies for some official torts, even those that do not independently violate fundamental rights. The history of the development of federal question cases and tax remedies suggests the constitutional necessity for trespass remedies or their equivalent. Indeed, federal question constitutional actions as we know them would not have emerged absent a presumption of the availability of remedies for trespass. Similarly, a presumption that remedies were available for taxes illegal under either federal or state law seemed to underlie federal court practice prior to the enactment of the Tax Injunction Act and to be reflected in the Act itself.

On the other hand, the historical record also suggests that individual official trespasses alone are not and should not invariably be treated as federal question cases, even though they may implicate deprivations of liberty or property by the state. Lawsuits that the Court entertained under the 1875 general federal question statute-whether they concerned taxes, rate regulation, or seizures of property under other regulatory provisions-emerged from diversity cases that combined a trespass action with a constitutional issue as to the validity of the legislation under which an officer attempted to justify his trespass. As discussed in Part III, it is possible to discern in the older decisions

407. See, e.g., Bator, supra note 343, at 52 (discussing Monroe's holding that the federal constitutionul remedy was not merely a backstop remedy, but rather a remedy of first resort); Michael Wells \& Thomas A. Eaton, Substantive Due Process and the Scope of Constitutional Torts, 18 GA. L. REV. 201, 211 (1984) (noting the inconsistency between the Parratt opinion and Monroe's holding that $\S 1983$ supplies a remedy even if state law also supplies one).

408. Thus both systemic violations of nonfundamental primary rights or systemic denials of remedial rights for ad hoc violations of nonfundamental rights might secure a federal forum under Parratt. See supra note 401 .

409. See, e.g., Fallon, supra note 17, at 311 .

410. See, e.g., Leon Friedman, Parratt v. Taylor: Opening and Closing the Door on Section 1983, 9 Hastings CONST. L.Q. 545, 546-47 (1982) (criticizing Parratt's inconsistency with Monroe); Rosulic Berger Levinson, Due Process Challenges to Governmental Actions: The Meaning of Parratt and Hudson, 18 URB. LAW. 189, 203 (1986) (criticizing Parratt's application to claims of substantive due process for relegating civil rights claims to a state forum unless the state failed to provide a remedy). 
a requirement that adequate remedies be available for involuntary payments of taxes illegal under state law. But the allegation that a tax violated state law alone normally would not have sufficed to create federal question jurisdiction. In other words, a federal due process claim was not ordinarily presented when the allegation was that the state had collected taxes (or taken property) in violation of its own law. Instead, to obtain a federal forum the litigant had to plead a more substantial federal issue, such as that the tax statute or system violated the Commerce Clause, the Equal Protection Clause, or another specific constitutional guarantee. ${ }^{411}$ Thus, while the Cour had expansively construed the jurisdiction of the federal courts so as to allow them to decide federal questions no matter what the jurisdictional basis, the Court had not allowed for jurisdiction based on the presence of federal questions absent a claim with a clear connection to specific federal statutory or constitutional provisions. ${ }^{\$ 12}$

Monroe, although representing the heightened actionability under $\S 1983$ of ad hoc violations of constitutional rights (as distinguished from statutory or systemic violations), otherwise bore a strong similarity to the early emergent federal question cases: It combined a background right against an officer's trespass with a salient federal issue-in Monroe, the violation of the Fourth Amendment-that would negate a defense of justification for the seizure. ${ }^{+13}$ By the time of Monroe, constitutional law had developed to the point that it was fairly clear that a state official's random and unauthorized search or seizure could violate the Fourth Amendment; ${ }^{4+4}$ the fighting issue was whether a $\S 1983$ suit should be the vehicle to remedy the federal constitutional right. By contrast, antecedent to the issue of the availability of a federal forum for the random violation of a constitutional right in Parratt was the issue of whether random tortious behavior by government officials should be considered a constitutional violation at all. Parratt presents the official trespass by itself, without the added leavening of a more salient federal

411. See supra notes 363-364 and accompanying text; see also Londoner y City of Denver. 210 U S 373, 381 (1908) (upholding a procedural due process challenge where the assessment statute did not explicitly require notice of the time of hearing on assessments and such notice had not been provided). Madisonville Traction Co. v. Saint Bernard Mining Co., 196 U S 254 (1905) (noung in a diversity condemnation case that the questions of amount and of whether the local statute authonzed the condemnation ordinarily would not involve federal rights that the Court could consider on direct review)

412. The allowance of federal question jurisdicuon based on federal incorporation. however. may be an exception. See, e.g., American Nat'l Red Cross v. S.G., 505 U.S 247 (1992) (approving federal question removal based on provisions in a federal charer that an entuty could sue and be sued in federal coun). discussed in HART \& WECHSLER, supra note 1, at 898-99 (quesuoning whether it made sense to allow the Red Cross to litigate state law actions in federal courts without regard to diversity)

413. See Monroe v. Pape, 365 U.S. 167, 187 (1961) (stating that $\S 1983$ "should be read aganst the background of tor liability that makes a man responsible for the natural consequences of his actions")

414. See, e.g., Irvine v. California, 347 U.S. 128, 132, 136 (1954) (finding a volution of the Fourth Amendment although not applying the exclusionary rulc): of Home Tel. \& Tel. v Crty of Los Angeles. 227 U.S. 278, 287-96 (1913) (asserting that the Fourteenth Amendment protects against wrongs commilted by state actors, even if the wrong also violates state law): Ann Woolhindler. Demodeling Habeas. 45 STAN L. REV. 575, 617-30 (1993) (discussing the long-term declune of an exclustve focus on statutes as the gnst of constitutional litigation). 
issue in the form of a challenge to a statute, to a systemic practice, or to an ad hoc denial of a fundamental constitutional right. ${ }^{415}$

To determine whether state law trespasses raise sufficiently substantial federal issues to warrant the exercise of original federal court jurisdiction under $\S 1983$, one need consider only the state court suits that the $\S 1983$ action would parallel if such a $\$ 1983$ action were recognized. One can measure the federal content of such putative $\S 1983$ suits by asking whether such cases, if brought in the state courts, would present credible candidates for direct review. In the early federal question cases treated in Part III, such parallel state court actions presented clear federal issues for direct review. Poindexter $v$. Greenhow $^{416}$ was the state law equivalent of an early federal question damages action, and it was easy to find a federal issue for direct review in the constitutional challenge to state statutes under the Contracts Clause. Similarly, absent a $\S 1983$ remedy, the Supreme Court on review of a state law trespass action on the facts of Monroe might have applied Fourth Amendment principles (which it was then increasingly elaborating in criminal cases) ${ }^{417}$ to limit officers' defenses of justification to the claimed trespass.

By contrast, looking to the state court actions for which plaintiffs in cases such as Parratt sought to substitute federal court $\S 1983$ actions, one would rarely find a credible candidate for direct review. To be sure, Parratt-type cases that arise in state court might present federal issues, but only at practically the same obscure level that any ordinary state law civil action coming from state court might. Civil actions may always present procedural due process issues, in the sense of a background requirement that the state provide fair procedures to determine whatever it is that state substantive law happens to make relevant to a particular claim or defense. ${ }^{418}$ And the substantive legal standards that are relevant to claims and defenses must meet requirements of rationality. ${ }^{419}$ But while there are requirements of fair procedures to determine substantive standards, as well as requirements that substantive standards be rational, the Supreme Court will not ordinarily police

415. See, e.g., Wells \& Eaton, supra note 407, at 211-12 (distinguishing Parratt from Monroe in that the plaintiff in Parratt relied solely on the Due Process Clause); id. at 212 (stating that the danger of constitutional tort theory taking over matters best left to the common law is greater when the claim asserts a general injury to life, liberty, or property than when a more specific constitutional right is at issue).

416. 114 U.S. 270 (1884).

417. See, e.g., Beck v. Ohio, 379 U.S. 89 (1964); Stoner v. California, 376 U.S. 483 (1964); Mapp v. Ohio, 367 U.S. 643 (1961); cf. Irvine, 347 U.S. at 134-36 \& n.5 (collecting cases, principally involving federal prosecutions).

418. See Fallon, supra note 17, at 329-39. That what constitutes "property" may be largely state-lawdefined does not negate some federal content. See id. at 329 . The idea of a mandatory trespass action implies some baseline concept of property. Procedural due process itself interjects federal content into state definitions of property. See Frank H. Easterbrook, Substance and Due Process, 1982 SUP. CT. REV. 85. 85 (arguing that it is illogical for the Court to give a legislature control over substance while the Count retains the privilege to determine procedures to be used to evaluate claims of entitlement).

419. See Fallon, supra note 17, at 315-16; see also Henry J. Friendly, "Some Kind of Hearing," 123 U. PA. L. REv. 1267, 1316 (1975) (stating that the Court has been vague as to the requirements of duc process apart from the field of creditors' preliminary remedies). 
whether state procedural and substantive rules were followed in individual cases. ${ }^{420}$ Rather, any review is likely to be for statutory invalidity or other systemic failings. ${ }^{421}$ Background constitutional guarantees of fair procedural systems and rational substantive rules hardly require characterizing all state law cases as raising federal issues for direct review purposes, despite these ubiquitously embedded, low-grade due process and equal protection issues.

The older tax cases and the newer line of cases following Parratt differ from ordinary civil cases, but not by much. Their requirements for procedural due process-that is, fair procedures to determine substantive law-may not substantially differ from any ordinary civil action litigable in state court. 22 They differ in that the Federal Constitution may require substantive liability and remedial rules that are not merely rational, but that also are designed to compensate for governmental harms in certain circumstances. ${ }^{.23}$ Just what those circumstances are, however, is not entirely clear. ${ }^{424}$ There may be requirements for compensation in some classes of cases, but whatever policing

420. See, e.g., Barney v. City of New York, 193 U.S. 430 (1904) (rejectung claums that a falure to comply with state law violated due process). Staled differently, the Coun will not allempt to determine whether a fair and rational result under applicable law was reached in a particular civil action. Requirements of fair procedures to determine compliance with stite substanuve rules and the requitements of rationality of the substantive rules unite in directed verdid standards. Such rules exist to ensure jury rationality by requiring evidence of sufficient facts from which a jury could raltonally conclude that the substantive standard has been met. See, e.g., FED. R. CrV. P. 50. In the criminal context, the question of sufficiency of the evidence is said to present a due process question, allowing for both direct and collateral review in federal court of the rationality of the state cour jury determinituon. See Jackson $v$ Virginis. 443 U.S. 307 (1979). But as a general matter, the Courn has not explicitly imposed directed verdict standards in state civii cases litigating state law claims, much less policed a directed verdict standard in individual civil cases.

421. See Fallon, supra note 17, at 311. To the extent a state coun announces a rule of law of some generality, an individual case may become a systemic one. See. e.g. Peralta v. Hetghts Med. Cu.. 485 U.S. 80, 83-84 (1988) (overturning a state court ruling, apparenty basod on state common law, thal required a party seeking to overturn a default judgment entered without notice to show a mentonous defense)

422. See Zensky, supra note 372, at 202 (stating that procodural adequacy of post-depnvation relief must meet at least the same minimum due process standards of famess and accuracy applicable to any government proceeding adjudicating rights and liabilities); 1 . at 205 (suggesung that, at tumes. Parratt-lype cases may require more than the minimum procedural duc process standards).

423. See Brown, supra note 369 , at 856 ("By dictating that a state provide an adequate remedy where it has interfered with property, the Coun is grantung a greater propeny interest than inually crealed by the state. Such a position is inconsistent with the Court's traditional postuon that the founcenth amendment itself does not define property."): Monaghan. supra note 404 , at $986 \mathrm{n.58}$ ("[B/oth the nature of the substantive duties imposed on state officials by the foureenth amendment and the extent to which the state must provide remedies for their violation are matters of substantive due process."): Smolla. supra note 397. at 878 (concluding that while Parratt gives states considerable license to develop thetr own ton rules. including highly restrictive statutes of limitations and doctrines of ummunty. there should be federal review slightly more rigorous than minimal rationality review). There may be some reyutred federal substantive content to state tort rules more generally, but not such as to produce federal issues in the great run of cases.

424. See Martinez v. California, 444 U.S. 277 (1980) (holding that there was no due process violation in a state's providing parole officers immunity to a wrongful death clatm): Smolla. supra note 397. at 871 ("To say that Parratt . . . involvels] modest federal scrutiny of the adequacy of state tort rules is one thing; to work out the details of that scrutiny is quite another."): see also Fallon, supra note 17. at 342-44 (discussing which remedies should be considered adequate); Wells \& Eaton, supra note 407, at 246-47 (same); Zensky, supra note 372, at 208-26 (same). 
there is will likely remain at the systemic rather than the case-by-case level. ${ }^{425}$ And even at the systemic level, the Court may be unlikely to do more than sketch out the requirements of adequate compensatory schemes. ${ }^{426}$

To say that the details of due process rights in many ordinary governmental tort cases may be unworthy of federal question treatment on either direct review of state court decisions or in original $\S 1983$ cases is admittedly largely descriptive. It does not answer the normative question of whether the Court should enter into the thicket of elaborating federal standards regarding tort liability of state and local officers, beyond the policing that Parratt seems to contemplate. ${ }^{427}$ The recent forays of the Court into punitive damages issues show that aspects of background guarantees of procedural and substantive due process can percolate into full-fledged federal issues that the Court may attempt to particularize and to police on direct review on an individual, case-by-case basis. The punitive damages decisions, which otherwise involve only ordinary civil litigation between private parties, show the Court moving from requiring procedures and meaningful judicial review

425. See Fallon, supra note 17, at 311 ("[A]lthough we characteristically think of constitutional rights in individualistic terms, due process doctrine has developed a strikingly managerial aspect."); id. ("The ultimate commitment of the law of due process remedies-analogous to that of procedural due process-is to create schemes and incentives adequate to keep government, overall and on average, tolerably within the bounds of law.").

426. See, e.g., Bator, supra note 343, at 59 (stating that "there is no single answer as to how intense federal intervention should be"); Wells \& Eaton, supra note 407, at 209 (noting the desirability of maintaining flexibility as to the extent to which government should be liable in tort); Zensky, supra note 372, at 185 (noting that the Court had imbued the concept of adequacy of state remedies with a large range of substantive flexibility); cf. Burnham, supra note 404, at 556-57 (discussing the standard for what types of tortious behavior violate the Due Process Clause based on a notion of abuse of power that would require (1) that the loss must be caused by a government official in a position of power over the injured party or persons in the injured pany's position; and (2) that the injury must take place in the process of that official's exercising or attempting to exercise such power over the injured party).

427. Some scholars have resolved the problems of accommodating the Parratt line of cases to the Monroe tradition by characterizing the Parratt line as a form of abstention. See Fallon, supra note 17, at 345 (stating that Parratt would better fit with the surrounding doctrinal framework if it were recharacterized as an abstention case); Henry Paul Monaghan, Of "Liberty" and "Property," 62 CoRNELL L. Rev. 405 , 429 (1977) (arguing that it would be preferable to read $\S 1983$ as not embracing all liberty and property, rather than to define liberty and propenty narrowly); Monaghan, supra note 404, at 999 (stating that Parratt's narrowing results would be better treated as abstention or an interpretation of $\S 1983$ as opposed to an interpretation of due process). Others have indicated that one should consider Parratt to be only an interpretation of the Due Process Clause. See Smolla, supra note 397, at 867-71; see also Hakr \& WECHSLER, supra note 1, at 1149 ("The issues raised by the Zinermon case and its predecessors deal less with the problem of remedies for constitutional wrongs, or with the allocation of business between state and federal courts, than with the substantive content of the prohibitions of the Fourteenth Amendment."); Bator, supra note 343, at 56-57 (observing that Parratt reopens the question of Monroe at the constitutional level, not merely saying that federal jurisdiction is lacking, but rather that what is missing is the substance of a constitutional violation); Wells \& Eaton, supra note 407, at 203.04 (stating that the central issue in Parratt is when the substantive protections of the Due Process Clause are violated). The abstention characterization perhaps implies a higher level of federal content in such cases than they contain, in view of the fact that, absent a systemic problem, such cases rarely present solid federal issues for direct review. See Fallon, supra note 17, at 345 (noting that Parratt has a more draconian effect than abstention doctrines that merely shift litigation from a federal to a state forum without affecting the plaintiff's substantive claims). 
of punitive damages awards to insure the rationality of jury decisionmaking, ${ }^{428}$ to ad hoc reviewing of individual awards as a matter of substantive due process. ${ }^{429}$ The Court's decision to give specific federal content to punitive damages law as opposed to other potential due process issues arising in state civil cases (such as the rationality of civil verdicts more generally), may have been less a matter of a logical distinction from other issues of unfair wealth transfer and more a matter of widespread current perceptions of persistent arbitrariness in punitive damages awards. ${ }^{430}$ Similar concerns in the past had led the Court to provide heightened federal scrutiny of the reasonableness of utility rates, a scrutiny the Court subsequently relaxed after the perceived risk of arbitrariness subsided. ${ }^{31}$

While it may be difficult to draw the line between those issues that receive federal particularization under the Due Process Clause and those that do not, the lines are ones that ought to be drawn to maintain some appropriate division of functions within the federal system. ${ }^{432}$ Indeed, the Court has continually drawn such lines, even before the advent of the general federal question statute and the Fourteenth Amendment. The Supreme Cour early on drew a line between legislative and judicial impairments of contracts, not only because the language of the Contracts Clause explicitly speaks to the "pass[age]" of "laws," ${ }^{433}$ but also because of the desire not to federalize all contracts law. ${ }^{434}$ Judicial "impairments" through common law decisionmaking that

428. See, e.g., Honda Motor Co. v. Oberg. 512 U.S. 415 (1994) (holding that judicial review of the excessiveness of a punitive damages award was required by due process), Pacific Mlut Lare Ins Co $r$ Haslip, 499 U.S. 1 (1991) (upholding a punitive damages award in light of adequate guidance to junes and state coun judicial review).

429. See BMW of N. Am. v. Gore, 116 S. C. 1589 (1996) (overturning a puntuve dumages award after examining in an individual case the degree of reprehensibiluy, the ratuo of the punituve award to the actual harm inflicted, and the potential civil or cnminal sanctions for comparable misconduct). of TXO Prod. Corp. v. Alliance Resources Corp., 509 U.S. 443 (1993) (indıcatung that punuve damages awarus must meet a standard of reasonableness that exceeds mere rationality. but finding that the particulur award was not grossly excessive).

430. In addition, the Court may be concerned with misallocation of resources frum such awards and the potential impact on interstate commerce. Cf. Gore, $116 \mathrm{~S}$. C. At 1604 (undicaung that the federal interest in not having states impose undue burdens on interstate commerce was a consideration in the Court's review).

431. Cf. Drobak, supra note 277, at 68, 124 (noting that the Supreme Court has repestedly refused to review the constitutionality of state ratemaking for the past 40 years, but that constututuonal limus on ratemaking did not disappear with the demise of economic substanuve due process) Professor Drobak notes that modern constitutional limits on ratemaking are weak and result in litle judicial interference with ratemaking. See id. at 124 .

432. See, e.g., Fallon, supra note 17, at 350 (suggesung that Parratt as an abstention doctnne could be justified on the ground of not displacing traditional stute authonty): Wells \& Eaton, supra note 407, at 208-09 (stating that maintaining a line between common law and constuutional ton helps to reduce federal intrusions on state autonomy and preserves discretion and diversity in the development of ton law)

433. U.S. CONST. an. I, $\S 10, \mathrm{cl} .1$.

434. See, e.g., Bethell v. Demaret, 77 U.S. (10 Wall) 537. 540 (1870) (holding that the Loustand Supreme Cour's holding a contract for confederate currency invalud when entered into was not reviewable under section 25 of the Judiciary Act of 1789 as a federal question because "otherwise every judgment of the Supreme Court of a State would be re-examinable under the section"): Rulroad Co V Rock. 71 US (4 Wall.) 177, 181 (1866) (rejecting the argument that the Supreme Coun of lowa had violated the Contracts Clause by its decision against the validity of counly bonds. staning that "[a]t thus were the law. 
announced new rules retroactively impacted on myriad private contracts; to have declared that such judicial impairments violated the Contracts Clause would have effectively federalized much of state contract law. Analogously, when the Due Process Clause began to displace the Contracts Clause as the major source of constitutional litigation, the Court early on held that simple failures by state officials to follow state law (when no other constitutional rights were at issue) ordinarily did not implicate a due process violation. ${ }^{435}$ Such a decision seems inevitable if there is any continuing wish to maintain a federal system. But the same decision effectively means that the Supreme Court will not in fact police most low-level federal guarantees against governmental arbitrariness in civil litigation on a case-by-case basis. ${ }^{46}$ Even in areas where it was possible to discern requirements beyond those of minimal procedural due process and substantive rational rules, such as in tax refund actions, the old Court generally did not find federal questions for direct review or for original federal court jurisdiction unless specific federal guarantees might have negated the officer's asserted justification.

What is more, lying behind the background assumption that there is some constitutional compulsion for remedies for governmental trespasses is a further assumption that there must be a system of state remedies for private trespasses. Yet the instinct not to constitutionalize every case in which state courts have denied a remedy for a private trespass is powerful. In short, whether the case against Parratt is based on precedent or on the proper role of federal courts, the case has not been made. Rather, the Court's long-term accommodation appears to be grounded not just historically, but normatively as well.

\section{CONCLUSION}

This Article has shown that for much of this nation's history diversity jurisdiction served as an early form of federal question jurisdiction, and that the Supreme Court sometimes provided an expansive interpretation of diversity to accommodate constitutional claims. In such diversity actions, federal elements were not merely interstitial to state law. Rather, federal courts

every case of a contract held by the State court not to be binding, for any cause whatever, can be brought to this court for review"); Commercial Bank v. Buckingham's Ex'rs, 46 U.S. (5 How.) 317, 343 (1847) ("The power delegated to us is for the restraint of unconstitutional legislation by the States, and not for the correction of alleged errors committed by their judiciary.").

435. See, e.g., Barney v. City of New York, 193 U.S. 430 (1904) (holding that a violation of state law did not constitute a violation of due process); see also Londoner v. City of Denver, 210 U.S. 373, 378-79 (1908) (holding that there was no federal question presented in the allegation that the state court had incorrectly determined compliance with state law requirements); Hill, supra note 179, at 968 \& n.99 (noting the limitations of due process as applied to "wrong" judicial decisions).

436. Within the federal system, the Court has drawn a line between administrative actions beyond statutory authority and those that are unconstitutional, even though the former are logically violations of separation-of-powers principles and could therefore be characterized as constitutional violations. See Dalton v. Specter, 511 U.S. 462 , 470-75 (1994). 
followed an independent course in the provision of remedial rights against state officials, such that diversity-based federal question cases bore a greater resemblance to modern implied rights of action and $\S 1983$ cases than is usually supposed. Congress's provision of general federal question jurisdiction in 1875 and the Court's later recognition of federal question cases raising constitutional issues should thus be seen not so much as working a revolution in judicial federalism than as providing a new and expanded jurisdictional basis for parties to continue to do what they had done in the past.

Unlike in the federal courts, however, in state courts federal law was indeed interstitial to state causes of action. States were ordinarily free to structure remedies as they wished, and the Supreme Coun did not ordinarily force the states to supply remedies against themselves. Nevertheless, the Court sometimes compelled states to entertain actions in the nature of trespass against individual officers who acted under unconstitutional statutes. The trespass action thus served as a kind of constitutional baseline to guarantee remediation of official wrongs.

This underlying requirement of a trespass action against the officer not only animated the requirement of certain remedies in state courts and diversity actions raising constitutional questions, but also animated the emergence of federal question actions for redress of constitutional violations late in the nineteenth century. This three-tiered remedial system of compelled remedies in state courts, diversity constitutional cases, and federal question constitutional cases-all based on the presumptive availability of a baseline trespass action against governmental officers-was evident in the Court's Contracts Clause cases, rate regulation cases, and tax remedy cases.

This historical record sheds light on two continuing debates in federal courts law-the extent to which the Supreme Cour can ignore claims of sovereign immunity in cases originating in state courts, and the extent to which the federal courts should supply remedies for ordinary governmental torts. This Article suggests that the history of compelled constitutional remedies provides only a limited authorization for the Supreme Cour to treat sovereign immunity as inapplicable to cases arising in state courts. Accordingly, the Supreme Coun may properly require remedies against the state itself that are equivalent to the traditional trespass remedy against the individual officer only when the state has substituted a cause of action against itself for the traditional trespass suit against the officer.

This Article also finds support for the Supreme Court's refusal to provide a federal forum for nonsystemic deprivations of "nonfundamental" liberty and property interests in the line of cases associated with Parratt v. Taylor. On the one hand, ordinary government torts without a more crystallized federal issue historically were not treated as federal question cases for purposes of either direct review or original federal question jurisdiction. On the other hand, the historical record reinforces a silver-lining reading of Parratt, insofar as states 
may be constitutionally required to provide remedies as meaningful as those that existed at common law for many governmentally caused deprivations of liberty and property. 